\title{
Expected Macroeconomic Impacts of the Accession to WTO on Azerbaijan Economy: Empirical Analysis
}

\section{Khatai Aliyev}

Submitted to the

Institute of Graduate Studies and Research in partial fulfillment of the requirements for the Degree of

\author{
Master of Science \\ in \\ Economics
}

Eastern Mediterranean University

February 2014

Gazimağusa, North Cyprus 
Approval of the Institute of Graduate Studies and Research

Prof. Dr. Elvan Y1lmaz

Director

I certify that this thesis satisfies the requirements as a thesis for the degree of Master of Science in Economics.

Prof. Dr. Mehmet Balcılar

Chair, Department of Economics

We certify that we have read this thesis and that in our opinion it is fully adequate in scope and quality as a thesis for the degree of Master of Science in Economics.

Assoc. Prof. Dr. Sevin Uğural

Supervisor

Examining Committee

1. Prof. Dr. Mehmet Balcılar

2. Assoc. Prof. Dr. Sevin Uğural

3. Asst. Prof. Dr. Kamil Sertoğlu 


\begin{abstract}
World Trade Organization (WTO) is the largest trade organization which is supposed to open the international trade for the benefit of all countries through liberalization or removing impediments over trade. It may directly impact import and export and indirectly other macroeconomic variables. In this context, Azerbaijan's accession process to WTO has been subject to many discussions in terms of what impacts are expected for the economy in case of the accession. This thesis attempts to do an empirical analysis of the expected macroeconomic impacts of the membership on Azerbaijan economy through application of VAR model.
\end{abstract}

In this thesis, central question is what overall macroeconomic impact is expected for Azerbaijan's economy if Azerbaijan join to WTO. In this context, I hypothesize that macroeconomic impact of the membership over Azerbaijan economy is expected to be negative. To test my hypothesis, I benefit from the membership experience of Georgia and Armenia and use VAR model to estimate time series data for Georgia and Armenia individually, and panel data consisted of Georgia, Armenia and Azerbaijan's time series data. After all, I conclude that WTO membership increases import much more than export. However, the research fails to find enough evidence to say that overall impact of WTO membership is statistically significant. After taking Azerbaijan's economic characteristics into consideration, the research concludes that overall macroeconomic impact of WTO membership is expected to be negative for Azerbaijan.

Keywords: Azerbaijan, WTO membership, Macroeconomic impacts, VAR model 


\section{ÖZ}

Dünya Ticaret Örgütü (DTÖ) dünyanın en büyük ticaret örgütü olarak uluslararası ticaret üzerindeki engellerin kaldırılması veticari kazanç imkanlarının tüm üye ülkelere açılmasını hedeflemektedir. DTÖ, üyeülkelerin ihracat ve ithalatları üzerinde direkt, diğer makroiktisadi göstergeler üzerindeyse indirekt etkilerinin olacaği ön görülmektedir. Bu etkilerin hem positif, hem de negatif olabileceği göz önüne alındığında Azerbaycanın bu örgüte üyelik süreci, ve üyelikten sonra beklenilen makroekonomik etkiler bir dizi müzakerelere konu olmuştur. Bu araştırma konuya empirik açıdan yaklaşıp VAR modelini kullanarak Azerbaycanın DTÖ’e üyeliğinin gerçekleşmesi halinde beklenen makroekonomik etkileri bulmayi hedeflemiştir.

Bu tezin cevabını bulmaya çalıştığı en önemli soru üyelik gerçekleşirse Azerbaycan ekonomisi için ne gibi makroekonomik sonuçlar doğuracağıdır. Tezde kurulan hipotez çerçevesinde beklenen etkilerin negatif olacağı tahmin edilmektedir. $\mathrm{Bu}$ hipotezi test etmek için DTÖ üyesi olan Gürcistan ve Ermenistanın tecrübelerinden yararlanılarak VAR modeli kullanılmış, bu şekilde hem her iki ülkenin makroekonomin göstergeleri üyelik öncesi ve sonrasında yalnız olarak değerleğerlendirilmiş, hem de Gürcistan, Ermenistan ve Azerbaycan'ın makroeconomik göstergelerinin panel data olarak değerlendirilmesi yapılmıştır. Sonuç olarak DTÖ üyeliğinin ithalatı ihracattan daha fazla artırdığı tespit edilmiş, ancak üyeliğin genel etkisinin istatiksel olarak anlamlı olması için yeterli kanıt bulunamamıştır. Buna rağmen, Azerbaycan'ın kendine has ekonomik 
özelliklerideğerlendirilmeye katıldığında üyeliğin gerçekleşmesi durumunda genel etkinin negatif olacağı tahmininin doğru olduğu kanaatine varılmıştır.

Anahtar Kelimeler: Azerbaycan, DTÖ üyeliği, Makroekonomic etkiler, VAR model 
To my family 


\section{ACKNOWLEDGMENTS}

I would like to thank my supervisor Assoc. Prof. Dr. Sevin Ugural for this continuous guidance, support, opinion and encouragement in the preparation of this thesis. My thanks are not enough for her patient and continuous help. Moreover, I thank to Prof. Dr. Mehmet Balcilar for his valuable comments on my model building process.

I would like to express my special thanks to my family and everyone whom my love is for because of their invaluable and continuous support throughout my studies and my life.

Furthermore, I would like to thank all of my friends and one special person for their endless support and encouragement in my life. 


\section{TABLE OF CONTENTS}

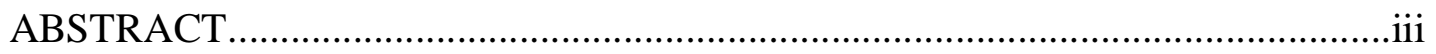

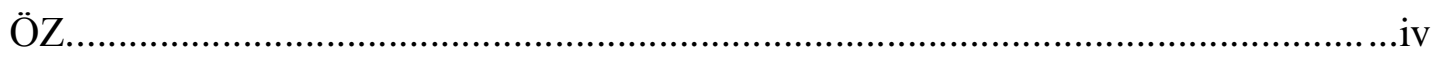

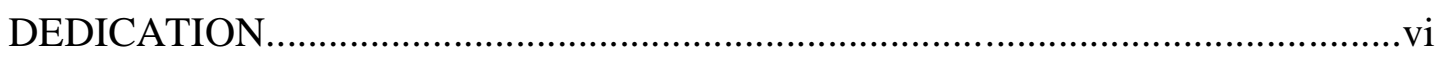

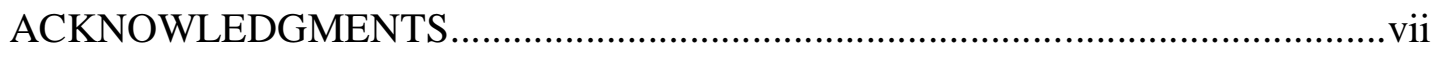

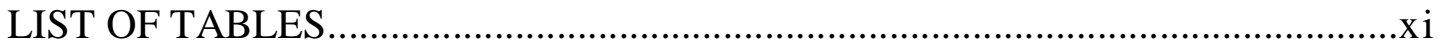

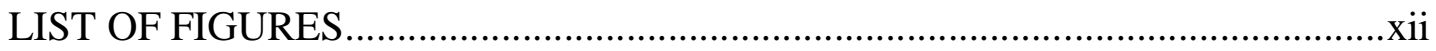

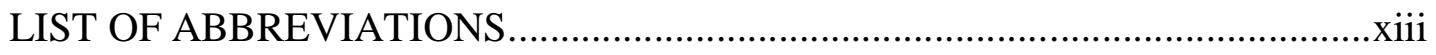

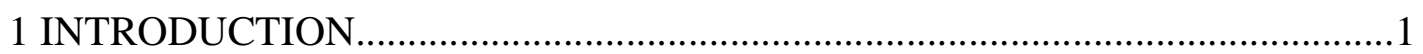

2 WORLD TRADE ORGANIZATION: FOUNDING, LEGAL BASIS, MAIN PRINCIPLES, DISPUTE SETTLEMENT SYSTEM, AZERBAIJAN'S

CASE

2.1 Founding of the World Trade Organization.................................................

2.2 Legal Basis of the WTO: Agreements....................................................

2.3 Does Mission of WTO Comply With Economic Theory?............................13

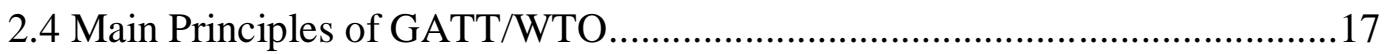

2.5 General Accession Process to WTO: Step by Step......................................21

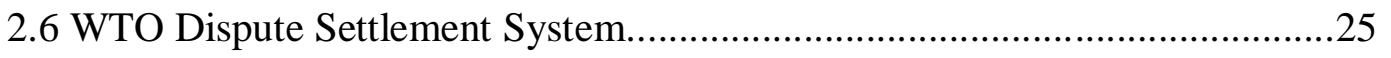

2.7 Azerbaijan's Case of the Accession to WTO...............................................28

2.7.1 Historical Outlook of the Accession.......................................................28

2.7.2 Current Situation on the Accession Process.............................................32

2.7.3 Reasons behind Delaying of the Accession Process...............................36

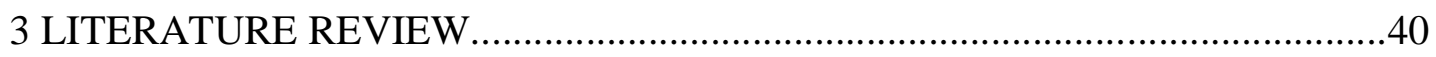

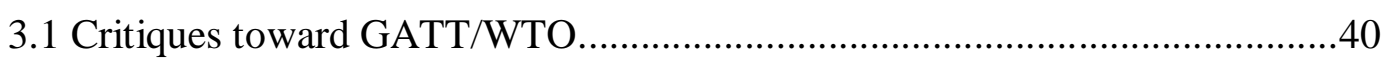


3.3 WTO/Trade Liberalization and Economic Growth.......................................51

3.4 Previous Researches on Azerbaijan's Case.................................................56

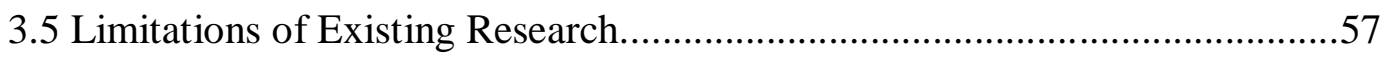

4 GENERAL ECONOMIC OUTLOOK OF AZERBAIJAN, GEORGIA AND

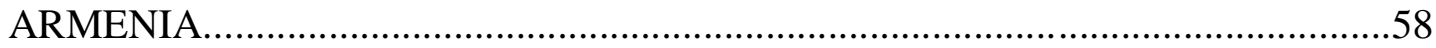

4.1 Azerbaijan Economy in Transition Period: Historical and Graphical

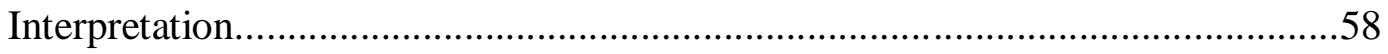

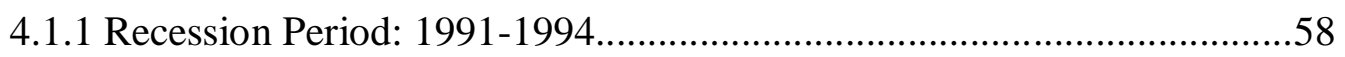

4.1.2 Restructuring Period: 1995-2005...........................................................61

4.1.3 Oil Boom Period: After 2005.............................................................66

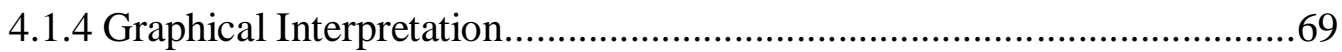

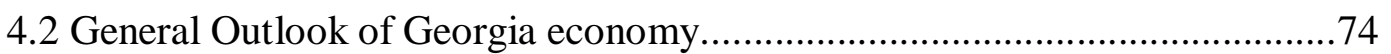

4.3 General Outlook of Armenia Economy......................................................... 79

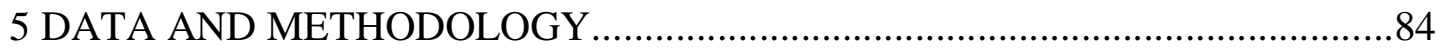

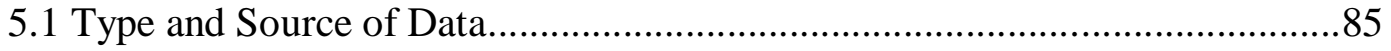

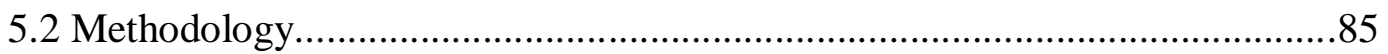

5.2.1 Why Georgia and Armenia together with Azerbaijan?...........................85

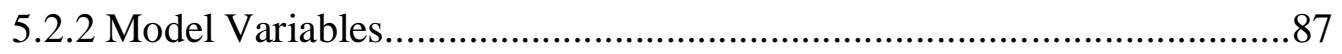

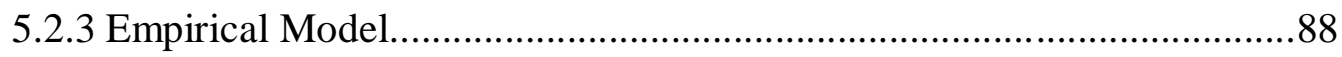

5.2.4 Testing for Stationarity: Unit Root Test..............................................93

5.2.5 Testing for Granger Causality........................................................94

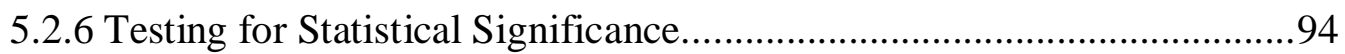

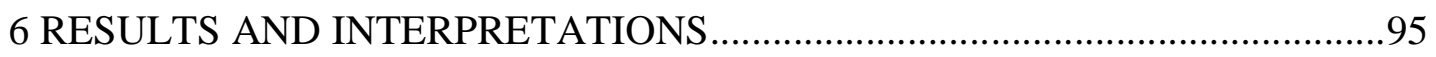

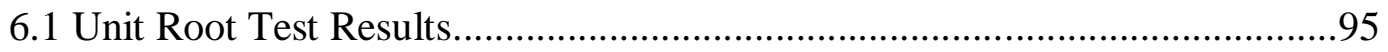


6.2 Pairwise Granger Causality Tests Results...................................................98

6.3 Interpretation of VAR Model Results.......................................................100

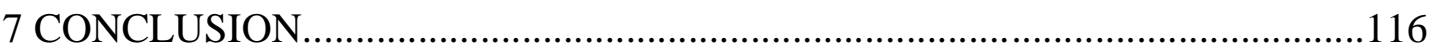

7.1 To Join or Not to Join? Policy Recommendations for Azerbaijan.................119

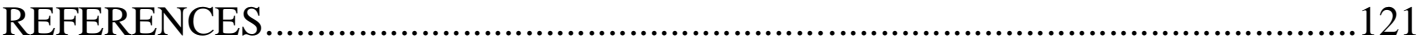




\section{LIST OF TABLES}

Table 4.1: Change in main macroeconomic indicators: $1990-1994 \ldots \ldots \ldots \ldots \ldots \ldots \ldots \ldots \ldots . . . . .60$

Table 4.2: Change in main macroeconomic indicators: $1995-2005 . . . \ldots \ldots \ldots \ldots \ldots \ldots \ldots \ldots . . . . .64$

Table 4.3: Change in main macroeconomic indicators: 2006-2012........................68

Table 6.1: ADF results for Georgia's VAR model...............................................95

Table 6.2: ADF results for Armenia's VAR model.................................................96

Table 6.3: Unit root test results for panel data series............................................97

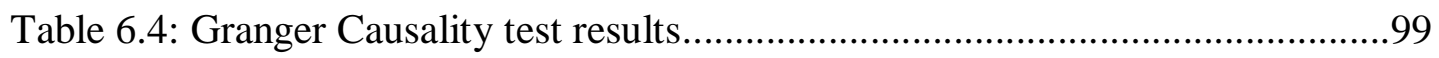

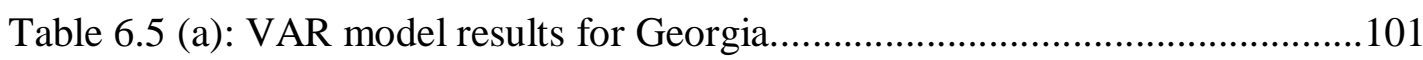

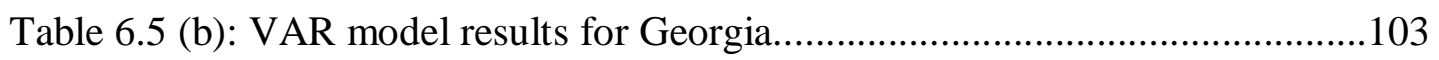

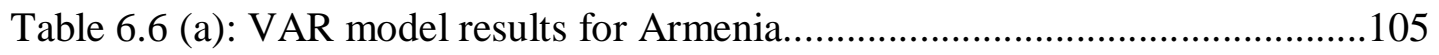

Table 6.6 (b): VAR model results for Armenia.....................................................107

Table 6.7 (a): Panel VAR model results without contrubition of oil-andgas

Table 6.7 (b): Panel VAR model results without contrubition of oil-and-

gas.

Table 6.8 (a): Panel VAR model results with contrubition of oil-and-gas

Table 6.8 (b): Panel VAR model results with contrubition of oil-and-gas. 


\section{LIST OF FIGURES}

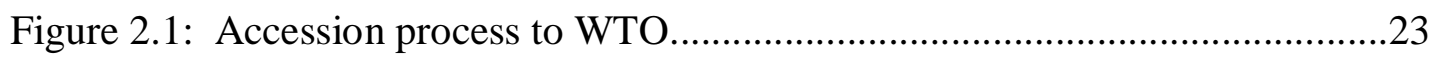

Figure 4.1: Trends in Azerbaijan Economy, millions USD....................................70

Figure 4.2: Comparative trends in Azerbaijan's GDP and GDP components, millions USD

Figure 4.3: Trends in Azerbaijan Economy, millions USD.....................................74

Figure 4.4: Trends in Georgia's GDP and GDP components, million USD..............75

Figure 4.5: Trends in Georgia's international trade, millions USD.........................76

Figure 4.6: Trends in Georgia's economy, millions USD.....................................78

Figure 4.7: Trends in Armenia's GDP and GDP components, millions USD...........80

Figure 4.8: Trends in Armenia's international trade, millions USD .........................81

Figure 4.9: Trends in Armenian economy, millions USD ......................................82 


\section{LIST OF ABBREVIATIONS}

\begin{tabular}{|c|c|}
\hline $\mathrm{AAC}$ & Absolute Cost Advantage \\
\hline $\mathrm{ADF}$ & Augmented Dickey-Fuller \\
\hline APF & Azerbaijan Popular Front Party \\
\hline BTC & Baku-Tbilisi-Ceyhan \\
\hline BTE & Baku-Tbilisi-Erzurum \\
\hline CCA & Comparative Cost Advantage \\
\hline CESD & Center of Economic and Social Development \\
\hline $\mathrm{CPE}$ & Centrally Planned Economy \\
\hline DSB & Dispute Settlement Body \\
\hline EU & European Union \\
\hline FDI & Foreign Direct Investments \\
\hline GATT & General Agreement on Tariffs and Trade \\
\hline GATS & General Agreement on Trade in Services \\
\hline GDP & Gross Domestic Product \\
\hline GSP & Generalized System of Preferences \\
\hline IDPs & Internal Displaced Persons \\
\hline ITA & International Trade Administration \\
\hline $\mathrm{MFN}$ & Most Favored Nation \\
\hline NAMA & Non-Agricultural Market Access \\
\hline PTAs & Preferential Trade Agreements \\
\hline SPSEDR & State Program on Social-Economic Development of Regions \\
\hline SOCAR & State Oil Company of Azerbaijan Republic \\
\hline SOFAZ & State Oil Fund of Azerbaijan Republic \\
\hline
\end{tabular}


SU

TRIPS

UAE

USITC

USA

VAR model

WTO
Soviet Union

Agreement on Trade-related Aspects of Intellectual Property Rights

United Arab Emirates

United States International Trade Commission

United States of America

Vector Auto Regressive model

World Trade Organization 


\section{Chapter 1}

\section{INTRODUCTION}

Today, WTO is the largest trade organization in the world including most of the world countries. It has a long founding story which starts in the second half of 1940s or more precisely, by signing the GATT agreement. During the all these years, GATT agreement has been subject to many trade negotiations and changed to GATT 1994 when WTO was created. Aim of the organization is enhancing trade liberalization and opening trade to all countries to benefit. The organization has several compulsory principles that must be followed by all member countries. On the other hand, a country who wants to join to the organization passes several stages and undertakes obligations for the WTO until its accession as a full member. Azerbaijan's accession process to WTO is one of such a case which has been started in 1997 but, not completed yet.

Although WTO is a world organization covering most of the world trade, it has been subject to many researches and discussions in terms of whether its impact on international trade and economies of the countries is significant or not. This became more popular with Rose's findings (Rose 2004a) through which he claimed that there is not "strong empirical evidence" to consider that "GATT/WTO has systematically played a strong role in encouraging trade". Consequently, that leaded to further studies in this field which by using different methods achieved different results where some criticized and some supported WTO. On the other hand, studies about 
the impact of trade liberalization over the economic growth of countries, which WTO membership is supposed to increase also produced different results. However, general conclusion is that a country may suffer from balance of payments deficit if the increase in import exceeds the increase in export after liberalizing its trade continuously.

In this context, this thesis aims to provide a comprehensive analysis of the WTO and the effects of membership that a nonmember country such as Azerbaijan should take into consideration. The main research question is "what kind of macroeconomic impacts are expected for Azerbaijan economy in case of its accession to WTO". Excluding political factors, the thesis discusses and graphically analysis trends in macroeconomic indicators of Azerbaijan economy after the year 1994. Moreover, this study includes discussing trends in some macroeconomic indicators of both Georgia and Armenia as the member countries of WTO. Analyzing Georgia and Armenia economies in before-and-after WTO membership context is supposed to create a general impression about what macroeconomic impacts may be expected for Azerbaijan economy in case of its accession. This analysis has been carried out graphically and empirically.

To estimate possible macroeconomic impacts of the accession for Azerbaijan, the research employs Vector Autoregressive (VAR) models for Georgia and Armenia individually and a panel data which include macroeconomic indicators of Georgia, Armenia and Azerbaijan. VAR model is applied on non-stationary and stationary time series data, separately.

The thesis is organized as follows: 
Chapter 2 gives information to understand WTO and Azerbaijan's accession process to this organization. Firstly, I explain historical foundation process of the GATT/WTO in light of reasons to the establishment and round of negotiations. Secondly, I look through the legal basis of GATT/WTO in terms of the main agreements such as General Agreement on Tariffs and Trade (GATT), General Agreement on Trade in Services (GATS) and Agreement on Trade-related Aspects of Intellectual Property Rights (TRIPS). Therefore, this enables one to define what restrictions and privileges the membership at WTO ensures for member states. Thirdly, I try to specify the theoretical base for foundation of the WTO according to previous studies related to this field. Later I discuss general accession procedure for WTO membership and at last, Azerbaijan's accession process in historical context with causes of delaying.

Chapter 3 covers previous studies on the impact of WTO over international trade and the impact of trade liberalization as a result of WTO membership over macroeconomic situation (economic growth, trade imbalances). Both criticizers' and supporters' studies about WTO are evaluated briefly. More precisely, the researches that find no significant impact of WTO (Rose 2004a, 2004b, 2004c; Gowa and Kim 2005; Park 2009; Eicher and Henn 2011; Roy 2011; Swinnen, Olper and Vandemoortele 2012) are discussed as parallel to the studies of the supporters of WTO (Subramanian and Wei 2007; Tomz, Goldstein and Rivers 2007a, 2007b; Balding 2010; Liu 2009; Dutt, Zandtand Mihov 2013; Konya, Matyas and Harris 2011; Kim 2008; Grant and Boys 2012; Herzl and Warner2011; Chang and Lee 2011; Anderson2010; Mansfield and Reinhardt 2008; Jansen 2010; Buthe and Milner2008; Shah, Hasnat and Li 2010). 
In chapter 4, I discuss the macroeconomic performance of Azerbaijan, Armenia and Georgia economies during the transition period. Azerbaijan economy is studied in more detail within three separated period: Recession (1991-1994), Restructuring (1995-2005), and Oil boom (after 2005) in terms of economic growth and growth performance in agriculture, manufacturing, industry, services, inflation and current account balance. Later, I give a graphical analysis of time series trends in GDP, sectoral production, export and import of Azerbaijan, Georgia and Armenia economies. Azerbaijan economy is analyzed in both oil-and-gas and non-oil-and-gas gas context.

Chapter 5 specifies the methodology for the empirical part of this thesis and indicates the sources of data which were used for estimation. In this part, Augmented DickeyFuller (ADF) test is used to test whether time series are stationary or not. Pairwise Granger Causality Test is used to find out the existence of granger causality between WTO membership and other variables in the models. Moreover, $\mathrm{t}$ test is used to find out if the coefficients are statistically significant.

In chapter 6, results of tests and VAR models are presented and interpreted. 


\section{Chapter 2}

\section{WORLD TRADE ORGANIZATION:FOUNDING, LEGAL BASIS, MAIN PRINCIPLES, DISPUTE SETTLEMENT SYSTEM, AZERBAIJAN'S CASE}

\subsection{Founding of the World Trade Organization}

World Trade Organization (WTO) was established in January 1, 1995, after the eight years of Uruguay Round of negotiations on the basis of the General Agreement on Tariffs and Trade (GATT). More precisely, WTO is considered as the successor of GATT and mainly based on the principles of GATT. Therefore, signing of the GATT should be considered as the first stage in creation of WTO.

The idea of GATT was derived from the Bretton Woods system and its was purposed to increasing the living standards, achieving the full employment, continuous rising of real income and effective demand, the "full use" of world resources and enlargement of goods production / trade through decreasing the tariff and non-tariff barriers over trade as well as removing of discriminatory trade policies in international trade in context of "reciprocal and mutually advantageous arrangements" (Irwin, 1995, p. 324). Although liberalization of international trade was considered as an essential tool to attain the monetary stability and full employment in the world, there was less attention to establish an International Trade Organization (ITO) until 1947 or signing of the GATT (Irwin, 1995, p. 325).

In 1947, first round of negotiations within the GATT with participation of 23 countries, by which $80 \%$ of total world trade was held, was organized in Geneva and 
devoted to reducing the tariff over trade. All participators were enforced to decrease their tariff levels over trade in the context of Most-Favored Nation (MFN) principle (maintaining equal conditions for all countries in trade). As a result of negotiations USA decreased its tariff levels by $35 \%$ on the average and became the leader in tariff cuts within Geneva round (Irwin, 1995, p. 325). That is why J. Pauwelyn (2005) in his article "The Transformation of World trade" has called the initial GATT as "a gentlemen's club" rather than a legal system with the intention of determining the problems over trade instead of making or explaining the trade law.

However, it should be noted that USA had increased its tariffs from $38 \%$ to $52 \%$ by "the Smoot-Hawley Tariff Act" in 1930 (Bagwell and Staiger, 2003, p. 14). Therefore, this "gentleman" action of USA in Geneva round of negotiations can be understood as decreasing the earlier increased tariffs. The enforcement mechanism of GATT was much more likely a "diplomatic procedure" aimed to preserve the "balance of concession" which was unable to provide objective enforcement of GATT rules and GATT was described as poor of discipline and law over the politics (Pauwelyn, 2005, pp. 13-14).

After Geneva round (1947), the negotiations within GATT were followed by new rounds, which were focused on the problems of trade as well. Thus, the level of tariffs were discussed in Annecy (1949), Torquay (1951), Geneva (1956) and Dillon (1960-1961) rounds of negotiations and after them Kennedy round (1964-1967) included anti-dumping issues and Tokyo round (1973-1979) added non-tariff measures and framework agreements into the list of subjects (Oatley, 2008, p. 26). Uruguay round (1986-1993) within GATT expanded the range of subjects to include 
services, intellectual property rights, textiles and clothing, agriculture, dispute settlement and hence to the creation of WTO (Oatley, 2008, p. 26).

In Kennedy round of negotiations, "anti-dumping" was included into the GATT agreement. Thus, the importer countries may impose "anti-dumping duties" over the imported products which supposed to be subject to damping as defined in Article VI of GATT 1994. As mentioned in the Article, the offered price of an imported product must be under the real value of that good in the exporter country in order to consider the case of damping. On the other hand, Tokyo round played an essential role in defining the developing and extending rules over the non-tariff measures as part of GATT's aim which was mentioned as decreasing or removing of non-tariff barriers and introducing those kinds of measures under the international discipline (WTO, 2012, p. 42).

Another important outcome of Tokyo round was signing some agreements aimed to develop the "systemic functioning" of GATT as the basic rules on multilateral trade system: "Differential and More Favorable Treatment, Reciprocity and Fuller Participation of Developing Countries", "Declaration on Trade Measures Taken for Balance of Payments Purposes", "Safeguard Actions for Development Purposes" and the "Understanding Regarding Notification, Consultation, Dispute Settlement and Surveillance" (USITC, 2003, pp. 20-21). All these were also called as framework agreements within the GATT.

Afterwards, Uruguay round added the services and intellectual property issues into the sphere of influence of GATT's main rules, decreased barriers on trade of services and adopted a "Final Act" about the 'protection of intellectual property' by all parties 
on the basis of Most Favored Nation principle that national governments were requested to treat all member countries equally and ensure the protection of intellectual property (Fieleke, 1995, pp. 10-14).

Uruguay round was the last round of negotiations within GATT, which is well known with creating the WTO on the basis of GATT. It considerably extended the scope of subjects within GATT which leaded to the establishment of international trade organization. The main reason in creation of WTO was that GATT was based on goods trade while WTO included trade in services and protection of intellectual property in context of its agreements as well (WTO, 2011, p.10).

Uruguay round ended with signing the "Marrakesh Protocol to the General Agreement on Tariffs and Trade 1994" on April 15, 1994 which added all outcomes of negotiations within GATT into this final agreement, called as the "GATT 1994". In addition to GATT 1994, "Final Act Embodying the Results of the Uruguay Round of Multilateral Trade Negotiations Marrakesh Agreement Establishing the World Trade Organization" included many other agreements such as General Agreement on Trade in Services (GATT), Trade-related Investment Measures (TRIMs), Traderelated Aspects of Intellectual Property Rights (TRIPS).

On November 2001, Doha Round of negotiations began on the subjects of agriculture, non-agricultural market access (NAMA), services, trade facilitation, rules, the environment, intellectual property issues, dispute settlement which were all targeted to increase market access in a simplified manner, maintaining protection of intellectual property rights and environment and making the Dispute Settlement of 
WTO much more understandable (WTO, a). Although Doha round was planned to end in 2005 negotiations in context of this round still continue in 2013.

To sum up, WTO is an outcome of long-lasting negotiations within GATT. In its mission statement, WTO was defined as an "international organization whose primary purpose is to open trade for the benefit of all" (WTO, b). It takes a broad range of activities on solving trade problems and making markets much more accessible for all participants of trade within WTO.

\subsection{Legal Basis of the WTO: Agreements}

As mentioned above, WTO was established on the basis of GATT. However, the legal basis of WTO is the "Final Act Embodying the Results of the Uruguay Round of Multilateral Trade Negotiations Marrakesh Agreement Establishing the World Trade Organization" which includes many agreements in itself. The main principles of WTO are based on mainly three agreements: General Agreement on Tariffs and Trade (GATT), General Agreement on Trade in Services (GATS) and Agreement on Trade-related Aspects of Intellectual Property Rights (TRIPS).

GATT 1994 included the all rules of GATT 1947 and all protocols and certifications about tariff privileges as well as all other decisions adopted by participated countries which all were about the trade in goods (GATT, 1994). This agreement restricted the foreign trade policy tools of member countries. Article I.1 demanded from governments of member countries to maintain equal conditions for all similar products from whole member states that any advantage, favour, privilege or immunity for a product must be granted to all others immediately as well (GATT, 1994). In addition, Article III of the agreement imposes member countries to ensure 
the "equality of competitive conditions" in internal market for both imported and domestic goods that domestic measures should not be aimed to protect domestic producers (GATT, 1994).

In compliance with GATT 1994, member countries must provide the same conditions for the 'traffic in transit' of all members, without any discrimination for production place and 'flag of vessels' (Article V) as well as customs valuation (Article VII). In addition, the 'freedom of transit' should be ensured within borders of any parties in terms of the best international routes for the transit. Article VI defined the framework of dumping and the policy toward anti-dumping in terms of "countervailing duties" which could be applied by and against all members of the organization. Article VIII of GATT 1994 emphasized that the import and export tariffs should be about the amount of custom services and must not be used as 'indirect protection' of domestic producers as well as 'fiscal purposes'.

Moreover, member countries were obliged to publish any changes in their trade regulations to inform other countries as well as importers and exporters (Article $\mathrm{X}$ ), remove application of quantitative restrictions over import and export for different purposes (Article XI-XII), apply non-discriminatory quantitative restrictions in case of its application (Article XIII), inform all member countries about the subsidization in detailed form if a country uses any kind of subsidy as well as "income or price support" (Article XVI) (GATT, 1994). However, member countries were allowed to use the flexible tariff rates in order to support the creation and development of a special industry which all are aimed to maintain the economic development of that member country (Article XVIII) (GATT, 1994). 
Article XXIV of GATT 1994 is also very crucial for the foreign trade policy of member countries, which define the framework of creating the customs unions and free-trade areas among members themselves. However, this article imposes on member countries that their trade regulations and duties must not be "more restrictive" in case of their membership to customs unions and free trade areas than the level of restriction through duties and trade regulations before the creation of those unions and areas (GATT, 1994).

On the other hand, GATS was purposed to create the 'multilateral framework of principles and rules' over the service trade among member countries of WTO in order to stimulate the economic growth and development of all parties as well as developing member states (GATS). Thus, this agreement imposes on members to create the equal conditions over the trade in services in the context of Most FavoredNation principle regardless the identity of service suppliers or the country (Article II) as well as maintaining transparency of everything related to all measures within this agreement (Article III). In addition, all members take the responsibility of providing the objective and fair application of the measures over trade in services as mentioned in GATS (Article VI).

Moreover, each member of the WTO is responsible to remove monopoly if there is, over service trade within its market and treat as consistent with responsibilities of members under the GATS (Article VIII). In addition, member countries are not allowed to impose restrictions over the "international transfers and payments" for actual transactions in context of special obligations out of permitted restrictions on service trade as only in case of critical balance of payments and foreign financial problems (Article XI-XII). On the other hand, member countries are constrained to 
apply limitations over the market access in terms of restrictions over the amount of service suppliers, total worth and amount of service operations (Article XVI) which they are obliged to treat against foreign service suppliers as equal with their own in terms of national treatment (Article XVII)(GATS).

TRIPS is another main agreement of WTO which is aimed to encourage the protection of intellectual property rights in member countries through providing rules and methods. Thus, members of WTO are forced to maintain the protection of intellectual property rights as much as demanded with this agreement through any eligible method in accordance with their own law (Article I) (TRIPS). In addition, they are obliged to treat equally against both national and foreigners in terms of protection of intellectual property rights as well as to create the same conditions for all property owners of other member countries (Article III-IV) (TRIPS). Moreover, member states are responsible to provide a law which should cover 'enforcement procedures' defined by this agreement in order to use against infraction of intellectual property rights as well as to include the quick solution for these cases but these procedures should not impose barriers over the legal trade (Article XLI) (TRIPS). Thus, these procedures should be 'fair and equitable' against all parties and should not become needlessly complex, time-consuming, expensive and delay(Article XLI) (TRIPS).

In addition to GATT, GATS and TRIPS, there are several other multilateral agreements within WTO which are mainly related to the trade in goods and define measures in connection with the trade in goods. Agreements on Agriculture, the Application of Sanitary and Phytosanitary Measures, Textiles and Clothing, Technical Barriers to Trade, Pre-shipment Inspection, Rules of Origin, Import 
Licensing Procedures, Subsidies and Countervailing Measures, Safeguards and Trade-related Investment Measures specify the certain measures over the corresponding fields of trade or the measures in specific subjects.

However, the legal documents which were mentioned above are only a small part of whole WTO legal texts. WTO legal texts include approximately 60 agreements and decisions which are 550 pages in total. Some of these are related to the interpretation of previous agreements or certain articles of GATT. Although all these constitute the legal framework of WTO, some disputes still rise among the members of organization which is tried to resolve through Dispute Settlement System within WTO. We will discuss this system in the next subchapter.

\subsection{Does Mission of WTO Comply With Economic Theory?}

There are different approaches to the creation of WTO as the successor of GATT. Some scholars explain why the GATT was created in context of hegemonic stability theory and some others approach to this issue from the economic point of view on the basis of comparative cost advantage theory.

Hegemonic stability theory is used to explain the success and failure of international cooperation in the certain conditions which argues that existence of a strong dominant actor in global politics causes to 'collectively desirable' results in terms of ensuring public goods for whole participants of the international system (Snidal, 1985, pp. 579-580). However, J. Ford (2002) claims that hegemonic state takes the advantage of "regime norms" in order to access to the markets of all thecountries and to ensure maximum level of profit for its "bourgeois class" through exploiting other states under the excuse of global utility (p. 120). 
Although neo-liberals consider GATT as an international public good in the context of hegemonic stability theory, it is the fact that GATT was mainly based on the interests of main industrial countries in alliance with USA and therefore, it should be considered as a trade system which was created within an alliance rather than a world free trade system (Walter, 1996). Thus, the reciprocal security interdependence encouraged the liberalization of trade among USA and Western European countries (Walter, 1996). Consequently, this makes suspicious the considering of GATT as a public good provided by the hegemonic state in context of hegemonic stability theory.

From a different perspective, founding of the GATT/WTO refers to the "static version of the theory of comparative cost advantage (CCA)" which supports international free trade (Shafaeddin, 2010, p. 176). However, the CCA theory was considered "strongly biased" because of the influence of classical theorists of international trade as well as their neo-liberal successors as supporters of free trade and trade liberalization at the international level (Shafaeddin, 2010, p. 176). CCA theory claims that international free trade is the best but, its assumptions are considered as "unrealistic" (Shafaeddin, 2010, pp. 176-177).

However, observing the import of absolutely advantaged goods in some cases due to use the factors of production in production of "more-valuable goods" which AAC could not explain caused to emerging of comparative advantage theory that despite of absolute advantage situation, some goods should be imported from less productive countries in order to employ the factors of production in more more-valuable goods' production (Fletcher, 2010, p. 94). The CCA theory assume that "trade is sustainable", "there are no externalities", "factors of production move easily between 
industries", "trade does not raise income inequality", "capital is not internationally mobile", "short-term efficiency causes long-term growth" and "trade does not induce adverse productivity growth abroad" which all are suspicious (Fletcher, 2010, p. 97104). Therefore, new models were established in order to explain the CCA.

Hecksher-Ohlin (H-O) model explains the comparative cost advantage among states in context of "factor endowments" of each state which define two factors of production - labor and capital- and stresses that the country is comparatively advantaged in production of labor based goods if it is labor abundant and another country has comparative cost advantage on capital based goods if it is capital abundant (Oatley, 2008, pp. 59-60). However, this model failed to explain the situation in foreign trade of USA after World War II. Thus, Leontief found out that the import competing goods of USA are much more capital based than its exports to the world which was called as Leontief paradox and as a solution, he offered to include the "qualitative" distinctions among labor factor in two different countries of the model (Rahim, 1999, p. 94). From this point of view, a worker in USA could be considered as equal to more than one worker of another country in context of qualitative distinctions which could make USA labor abundant as opposite to $\mathrm{H}-\mathrm{O}$ model.

On the other hand, Stolper-Samuelson emphasized that under assumptions of ceteris paribus and factor mobility among sectors of economy, the abundant factor in an economy will enjoy from freer trade and other factor of production with relatively lower amount will support protection which trade policy can raise the real income of people who owe the abundant factors of production "more than proportionally" (Alt, Gilligan, 2000, p. 330). 
Consequently, this will lead to decline of the production of labor intensive goods and increase of the capital based goods production. This will increase the real income of factors' owners which have been used in production of capital based goods and vice versa. Although the amount of used factors will decrease in labor intensive goods production, this theorem assumes that they will move and be used in the production of capital intensive goods in context of factor mobility among sectors of economy. However, the Ricardo-Viner model brought the notion of "specific factors" and emphasized that the factors of production "can not move" among different sectors of economy that those factors are "specific" for that sector (Alt, Gilligan, 2000, p. 332). More precisely, specific factors of production can move in some degree but, they will lose their value that "specificity" implies.

All these theories and models try to explain the free trade and specialization in context of static CCA of a country whereas some other scholars do not consider this as necessary that "dynamic comparative advantage" may be attained by government support and intervention within a certain time period (Shafaeddin, 2010, p.177). This also resembles the claim of Samuelson that "some trade is better than no trade, but this does not mean that free trade is always the best" (Shafaeddin, 2010, p.177).

To sum up, there are theoretically different approaches to the creation of GATT/WTO. Some scholars try to interpret it as political outcome and some others explain it in the context of CCA theory. However, hegemonic stability theory seems to be better in lighting this issue which both static and dynamic version of CCA fails to suggest the free trade as the "best" for all countries. Therefore, the aim of GATT/WTO becomes suspicious in terms of ensuring more liberal trade through 
removing of all barriers over trade in order to make all countries better off at least theoretically.

\subsection{Main Principles of GATT/WTO}

WTO is a trade organization that creates the framework of trade policies but it does not indicate the results of these policies. Thus, the organization is described as a "table" around which people discuss certain issues (WTO, 2011, p. 9). However, there are some principles that help to understanding of WTO/GATT agreements. Thus, Bernard Hoekman specifies five main principles such as "nondiscrimination", "reciprocity", “enforceable commitments", "transparency” and "safety valves" which have special importance in understanding of either GATT (until 1994) and WTO agreements (Hoekman, 2002, p. 42).

Under the principle of nondiscrimination, member states accept to impose the same level of tariffs on imported goods from all other members of the organization (Bagwell, Staiger, 1999, p. 217). This means that applied tariffs level of a member country (USA) is the same on import of a product (textile) from all participants of WTO, without any discrimination. Nondiscriminatory behavior in GATT agreement includes two main principles which are emphasized in Articles of the agreement: "General Most Favored Nation" (MFN) as mentioned in Article I and "National Treatment on Internal Taxation and Regulation" as indicated in Article III (Srinivasan, 2005, p. 72).

Thus, MFN principle demands that a member country must treat equally against products of all other WTO members during the import of those products in terms of imposed tariff levels, privileges and any other kind of granted advantages. On the 
other hand, another principle requires application of the same level of taxes and other regulations on imported products of other member states with the domestic products of a member in its internal market.

The reciprocity is another fundamental principle of GATT that a country admits to decrease the degree of its protection over trade as a response to the "reciprocal concession" from another country as its commercial partner which this implies the "ideal" level of reciprocal shifts in trade policy of different countries that leads to the approximately same shifts in amount of imports between trade partners (Bagwell, Staiger, 1999, pp. 216-217). Obviously, this is the key principle of tariff negotiations where participants try to achieve a "balance of concessions" that joining to negotiations is optional and requires willingness to set "reciprocal and mutually advantageous" decreased level of tariffs (Bagwell, Staiger, 1999, p. 225). More precisely, if two country (suppose USA and China) enter tariff negotiations, both of them are interested in mutually reducing of their tariff levels on products of each other. Thus, if the tariff concession between these two countries is "ideal", their amount of import from each other will change proportionally to the level of changes in tariff levels in terms of the achieved concession.

Application of reciprocity principle is observed in GATT/WTO when members of the organization legally desire to "renegotiate" the signed agreement in context of Article XXVIII of GATT which mentions that any member can suggest changes to previously agreed tariff concession or "withdraw" that concession. In these cases, if that country can not get success in negotiations about the "renegotiated tariff schedule" with other member countries, it can independently impose its suggested changes to tariffs and other countries are also allowed to withdraw approximately 
same level of their concession as a response to that country under the reciprocity principle (Bagwell, Staiger, 1999, p. 228).

'Bindings and enforceable commitment's is another principle which refer to the implementation of tariff commitments by member countries (Article II) which a WTO member can not impose tariffs higher than bound level or the highest level of allowed applicable tariffs without renegotiating this issue with other members, nontariff commitments (Article VII, XI) that forbids the application of non-tariff measures such as quantitative restrictions over import and other commitments of agreed documents (Hoekman, 2002, p. 43). Thus, if a member observe that another member does not implement its commitments or its attitudes does not comply with the principles and rules of WTO, firstly it can raise this issue at the government of another state and if the complaining state does not become gratified by the actions of another state's government, it can take this case to WTO for WTO dispute settlement procedures in order to determine whether this is the violation of WTO or not (Hoekman, 2002, p. 43). Obviously, WTO rules and commitments donot work sufficiently if the member countries are not forced to implement those rules and commitments.

The transparency principle has also crucial role in WTO activities in terms of ensuring stable and predictable trade law arrangements of WTO members which the "rule-oriented" external trade policy is based on this principle as well that includes both publishing of all appropriate arrangements in order to make them achievable for all parties before their implementation and notifying WTO and all other members about the actions of its government by a member country (Matsushita, 2004, p. 368). Thus, Article X of GATT 1994, Article III of GATS and Article LXIII of TRIPS as 
well as other agreements of WTO ensures the transparency rules for the activities of WTO and its member countries (Matsushita, 2004, p. 368). Therefore, transparency principle of WTO demands that all regulations and commitments of member countries as well as WTO itself must be made available for all parties and public. In this sense, if a member country intends to change the tariffs level, firstly it must publish this arrangement for the public and only after this it can be applied.

Although all principles that we discussed above serve to support the free international trade, last principle has an opposite effect over free trade. Thus, safety valves principle authorizes governments of member states to "restrict trade" in some conditions in order to providing fair competition, achieve its "non-economic objectives" and interfere in trade because of economic causes (Reis, 2009, p. 49). Governments restrict the trade in case of dumping in order to maintain fair competition in trade. In addition, non-economic objectives of a government can be protection of national security, public health and heavily injured industries with the effect of imported goods which governments are allowed to restrict the trade for. Moreover, if governments face with severe balance of payments difficulties or are interested in development of an infant industry, WTO agreements allow to restriction of the trade in some level as well.

After all, we conclude that although the aim of WTO is creating freer trade in the world which its most of principles serve for this aim, it also supports the protective actions of national governments in some cases. However, this raises the question that whether such kind of actions are really required for that country or if restrictions of a government under safety valves principle is fair or not. Consequently, this causes 
disputes among different countries which will be discussed in the context of dispute settlement system of WTO.

\subsection{General Accession Process to WTO: Step by Step}

WTO is open for accession of new members into the organization. It is the largest trade organization in the world with 159 members according to data of March, 2013 which provides both benefits and costs to the member countries. Despite some costs and independent trade policy restrictions, many countries also attempt to obtain the membership status in the organization, such that 24 more countries are on the way of accession to WTO as well. In this sense, it would be better to discuss the expected benefits and costs of the accession for potential WTO members before discussing the accession process itself.

Membership to WTO ensures some advantages such as much more trading opportunities with WTO members, higher level of transparency of policies over the trade, more reliable and presumable situation for the trade, rights to benefit from the advantages of WTO agreements, accession to dispute settlement mechanism of WTO in order to assert their trade rights and national interests and participation rights in multilateral trade negotiations of WTO (Ognivtsev and Jounela and Tang, 2001, pp. 176-177). Thus, accession to WTO provides broad range of benefits at least theoretically and in this sense, non-member countries seek to become a full member of WTO.

However, WTO is not all about benefits or advantages in terms of WTO principles and obligations by members of the organization. Thus, the membership causes some difficulties, especially for small states in terms of costs derived from the compliance 
to WTO as well as decreasing of the policy autonomy (Wangdi, 2010, p. 56). Thus, new members take responsibilities to make their trade policies compatible with the principles of WTO and this means loss of trade policy independence. On the other hand, states face with the strong competition of advanced economies after their accession, especially in agricultural goods and this is the main source of concerns of developing countries.

Despite of some disadvantages of WTO membership, world countries are interested in accession to the organization. The accession procedure was specified in the document "Accession to the WTO - Procedures for Negotiations under Article XII" that defines the framework of a non-member's accession process to WTO (Williams, 2008). However, a country can obtain an observer status for five years in WTO in order to become well informed about WTO as well as its activities before its accession as a member (Markovic, 2009, pp. 118-119). This status does not impose any commitment on that country. Figure 1.1 represents general framework of an accession process.

In short, membership procedure of a country includes six staged accession process (Markovic, 2009, p. 119). As mentioned in the figure above, procedure starts with official request submission by the government of the candidate country. This request must indicate the desire of that country to accept the Marrakesh Agreement and to become a member of WTO, which should be submitted to the WTO's General Director. Afterwards the request is introduced to all members of WTO and included to the agenda of General Council's subsequent meeting. 


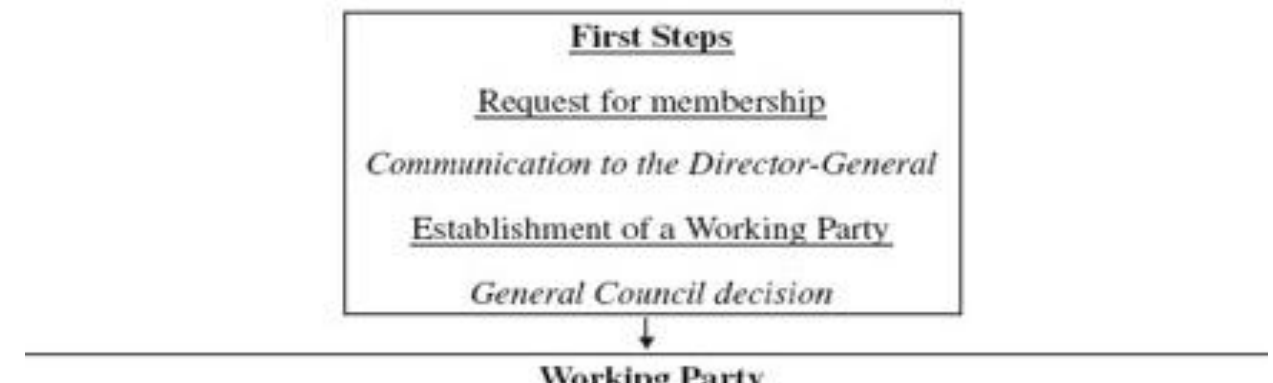

Working Party

Fact-finding stage

Submission of a Memorandum on the Foreign Trade Regime; supporting documentation; responses to questions from members; Other documentation, as requested.

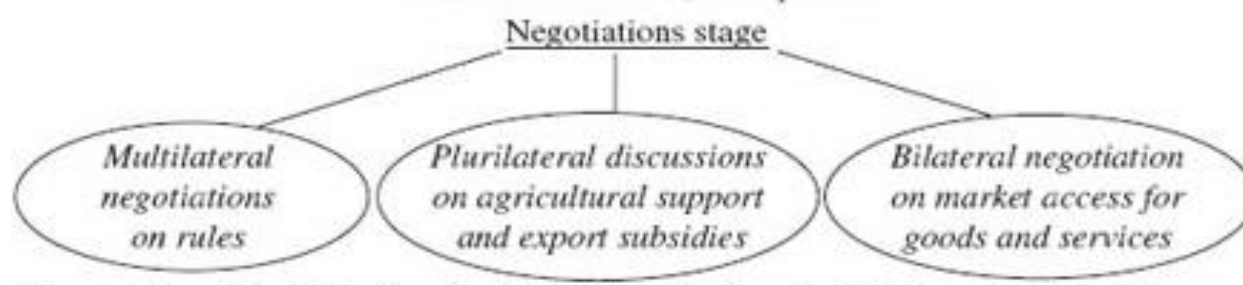

Preparation of draft Working Party Report, including draft Protocol and Decision, and draft Schedules on Goods and Services

Completion of the Working Party's Mandate

Adoption by the Working Party of its Report.

Adoption by the Working Party of its Report.
$\begin{gathered}\text { Final steps } \\ \text { Adoption of Working Party Report and terms of accession by General } \\ \text { Council/Ministerial Conference } \\ \text { Acceptance of Terms by the applicant by signature or otherwise. } \\ \text { Notification of acceptance by the applicant } \\ \text { Membership thirty days after notification of ratification or acceptance }\end{gathered}$

Figure 2.1 Accession process to WTO

Source: WTO

If the membership request of the country is adopted in the meeting of General Council, a Working Party is formed for this accession in order to look through the application of that country which all WTO members can participate in working parties (WTO). In the next stage, applicant country has to submit a "Memorandum on the Foreign Trade Regime" in order to clarify its policies and institutions which covers the explanation of its economic policies as well as external trade of goods and services, "trade-related intellectual property regime", agreements on the economic 
integration with other countries, "investments", "decision-making process" and statistical supplement (Eromenko, 2010, p. 43).

The statistical supplement includes data about the applicant country's trade, statutory acts, external trade agreements, surveys on "import licensing and customs valuation procedures", state enterprises in trade, technical restrictions over trade, "sanitary and phytosanitary measures", government support and subsidization of export in Agriculture, services trade as well as "trade related aspects of intellectual property rights" (Markovic, 2009, p. 120). Therefore, this memorandum is very important for the accession process that it constitutes the ground of future negotiations. Moreover, the applicant country presents an "Initial Schedule for Tariff Concessions for Goods" and an "Initial Schedule on Specific Commitments in Services" for WTO members as well (Markovic, 2009, pp. 120-121).

This is followed by bilateral negotiations among WTO members and the applicant country and if all negotiations are successfully ended, the WTO Secretariat formulate the "Accession Package" which include the "Working Party Report", "Protocol of Accession", the "Schedule of Concessions and Commitments on Goods" and the "Schedule of Specific Commitments on Services" (Eromenko, 2010, p. 44).

After all, if the Accession Package is accepted in the last meeting of Working party and confirmed by General Council of the Ministerial Conference, the applicant country approves the Protocol of Accession and obtains full membership status in WTO within the following one month. 


\subsection{WTO Dispute Settlement System}

As it is mentioned above, one of the reasons which encourage countries to join WTO is the opportunity to defend themselves or their trade interests in the international arena. Thus, they are allowed to bring cases to the Dispute Settlement system or more precisely Dispute Settlement body at WTO after their accession to the organization. In this sense, it is interesting to understand the dispute settlement mechanism of WTO and its effectiveness for developing countries.

Legally, dispute settlement system is based on the "Understanding on Rules and Procedures Governing the Settlement of Disputes" as the principal agreement on dispute settling which is the result of Uruguay Round as a part of the WTO agreement (WTO). However provisions on the dispute settlement within WTO were also emphasized in GATT 1994 (Articles XXII-XXIII), General Agreement on Trade in Services (Articles XXII-XXIII) as well as in agreements on Trade-Related Aspects of Intellectual Property Rights (Article 64), Implementation of Article VI of GATT 1994 or Anti-Dumping Agreement (Article 17), Implementation of Article VII of GATT 1994 or Customs Valuation Agreement (Article 19), Preshipment Inspection (Articles 7-8), Agriculture (Article 19), Application of Sanitary and Phytosanitary Measures (Article 11), Textiles and Clothing (Article 8.10), Technical Barriers to Trade (Article 14), Trade-Related Investment Measures (Article 8), Rules of Origin (Articles 7-8), Import Licensing Procedures (Article 6), Safeguards (Article 14) and Subsidies and Countervailing Measures (Article 4 and 30) (WTO, 2004, pp. 28-29).

Today, WTO Dispute Settlement Body (DSB) is authorized to implement the requirements of dispute settlement system which include all members countries' 
representatives and governs disputes among members of the organization. The disputes are brought to the DSB by governments of member countries if they think that another member country infringes the principles of WTO. In this sense, DSB initiates a settlement process for the brought dispute, which may take a long time period such as even 2-3 years. Because this is a too large topic and not much important for this research, we will not explain stages of a dispute settlement process with details. Thus, the focus of this part is much more on the effectiveness of dispute settlement process for developing countries.

Although WTO is supposed to maintain the equal opportunities to benefit from its principles for all member countries, it may be asked whether developing countries can really use this system to accomplish its economic interests or not. In this sense, theoretically WTO does this and even, it ensures some special treatments for them such as legal assistance and exclusive dispute settlement procedures in terms of quick settlement process and stimulating other countries to consider the situation of developing, especially least-developed countries (WTO, 2004, p. 111). However, all these are theoretically and even if all these would be maintained, there are still weaknesses of the Dispute settlement system in terms of developing country perspective.

Thus, despite of settling disputes regard to complain of a country, it still continues to suffer from the effects of WTO principles' infringement (as it claimed) during the dispute settlement process. Even, if the country won the dispute, it does not get any "compensation" for the damage of that infringement and it does not receive refund for its legal expenses related to the dispute settlement process (WTO, 2004, p. 117). In addition, developing countries are lack of specialists for the dispute settlement 
which make more difficult for them to defend their interests at DSB. Moreover, all developing countries in WTO are not successful to withdraw its obligations against another country of the dispute (respondent country) in case of "non-implementation" of WTO commitments even after ending of the dispute (WTO, 2004, p. 117). Consequently, all these have affected the statistics of disputes in terms of its distribution among member states regard to their economic development level as both complainant and respondent country.

Although 447 cases have been brought to DSB within the time period 1995-2010, the EU and USA have taken half of disputes as both complainant and respondent country while least developed countries have almost no participation (only one complainant case), approximately only $1 / 5$ of total cases belong to other developing countries excluding Brazil India and China (Horn and Johannesson, and Mavroidis, 2011, p. 8). Thus, only these three countries hold nearly $1 / 10$ (51 complainant and 55 respondent) of total cases (Horn and Johannesson, and Mavroidis, 2011, p. 8). However, unproportional distribution of cases is explained by the volume and richness of products in foreign trade rather than the amount of countries.

Anyway, the WTO Dispute Settlement System may not be considered as successful for the developing and least developed countries in terms of its weaknesses, which we mentioned above. However, it should be noted that it is better than the system of GATT 1947 and subject of the Doha Round of negotiations today. 


\subsection{Azerbaijan's Case of the Accession to WTO}

\subsubsection{Historical Outlook of the Accession}

The Republic of Azerbaijan had been a part of Soviet Union until 1991 with planned economic system. In 1991, Azerbaijan regained its independence and decided to change its economic system from planned to market economy. However, the transition process lasted so long which we will discuss later with details, one branch of this process was joining to international organizations.

Although, joining to the WTO was suggested to Azerbaijan by the World Bank representatives in 1996, starting point of the WTO "story" of Azerbaijan is considered as March 1997 or the meeting of Heydar Aliyev as the president of Azerbaijan Republic with USA's president Clinton, (Kavass, 2008, p. 343). Thus, at a press conference after the meeting, H. Aliyev declared that Azerbaijan will appeal for membership to the WTO. Consequently, Azerbaijan government prepared the required documents for the membership by his order and Azerbaijan sent an official application to the WTO on $23^{\text {rd }}$ June 1997 and WTO General Council adopted its application on $16^{\text {th }}$ July 1997 which gave it an observer status in the WTO as well as created a Working Party on the accession of Azerbaijan (Kavass, 2008, pp. 346-347).

However, Azerbaijan's economic conditions in time of the application were interesting in context of the desire for WTO membership. As we will see while discussing economic transition of Azerbaijan, production potential of the country was seriously destructed by the economic crises of 1991-1994. Moreover, its foreign trade was mainly based on "special agreements" (9/10 of foreign trade) (Kavass, 2008, p. 344) in the context of the "Contract of the Century" signed between 
Azerbaijan government and world oil companies. Thus, country's import was mainly consisted of investment goods for oil and gas production under that contract. On the other hand, most part of its export was also oil and oil products. In this sense, the reasons behind the application for the membership are seemed out of economic based in the perspective of Azerbaijan Republic.

Anyway, Azerbaijan expressed its interest to improve the accession process. However, the country was lack of experience or knowledge to respond the requirements of WTO accession in terms of submitting requested documents (memorandum on its foreign trade regime, etc.) and replying asked questions by members of the Working Party (Kavass, 2008). As a result, the first meeting of Working Party was delayed until 2002. In this sense, European Union, the USA and the World Bank had played an active role in terms of the assistance for the government of Azerbaijan to prepare the required documents as well as training authorized personals for the accession.

Although the first meeting of the Working Party was held in June 2002, there was a not significant improvement in the accession process at least in terms of submitting required documents and replying the questions of the Working Party members (Kavass, 2008, p. 355). However, Azerbaijan government with the support of USA accelerated preparation and submitting of required documents to the WTO on time. As a result, the second and third meetings of Working Party were held on October 12-15, 2004 and on June 27-July 1, 2005 respectively. At these meetings, submitted documents of Azerbaijan were discussed as well as Working Party members were informed about general economic environment of the country. In addition, the third Working Party meeting was accompanied by the multilateral negotiations on 
agriculture with participation of USA, Australia, Canada, Malaysia and bilateral negotiations with USA, EU and Canada on services and tariffs.

The accession process of Azerbaijan was continued with fourth (March 30, 2006) and fifth (May 6, 2008) meetings of Working Party which multilateral negotiations on agriculture and bilateral negotiations with USA, EU, Turkey, Taiwan, Canada, Japan were held under the framework of this meetings. Moreover, the government of Azerbaijan submitted required documents for the accession at the fifth meeting and as a result, preparing the "Factual Summary on Azerbaijan" was decided. At the sixth meeting, Azerbaijan side informed participants about the importance of non-oil sector's development as well as diversification issue in Azerbaijan economy which declared its desire to become a member of WTO as "Landlocked Developing Country".

Although the USA and EU expressed that Azerbaijan should be acceded with “developed country status" at the seventh meeting (July 24, 2009), Azerbaijan stressed its economic concerns such as diversification issue and insisted on becoming a member of WTO with developing country status. Moreover, USA and EU suggested Azerbaijan to cease the government support as subsidies to the agriculture sector but, Azerbaijan representatives stressed the significance of this sector once more at the meeting. At the next meeting (October18, 2010), Azerbaijan submitted its revised offers for goods and services based on its economic interests as well as a justification for its purpose to become a member of WTO with developing country status. 
In context of ninth meeting of the Working Party (February 24, 2012), bilateral negotiations were held with USA, EU, Norway, Japan and Canada on goods and services as well as with Ecuador only on goods and it is requested to decrease bound level of tariffs, join sectoral initiatives completely and increase market access liberalization in service sector of Azerbaijan. Moreover, Azerbaijan's offers about the government support to agriculture were discussed at multilateral negotiations on agriculture and members of the Working Party, especially Canada and Commonwealth of Australia disagreed with Azerbaijan's target to obtain 10\% de minimus right for internal support to the agriculture.

However, at the next meeting (December 7, 2012), Azerbaijan reemphasized its position to obtain $10 \%$ de minimus right as well as direct support in amount of $\$ 2$ billion to the its agriculture sector for every year. Although this was considered as impossible in previous negotiations, USA, EU, Canada, Commonwealth of Australia and Brazil emphasized its possibility for a certain time period after the accession. At the same time, bilateral and multilateral negotiations were held with some member countries over different issues in this meeting as well.

In time of my writing this thesis, this is the last meeting of Working Group on Azerbaijan. However, new meetings are also expected to be held because, Azerbaijan still is not a member of the WTO. It is at the stage of multilateral and bilateral negotiations of an accession process. Despite of remaining many issues, Azerbaijan's accession path to WTO indicates that there is a trend toward achieving the final agreement in terms of concessions during the process. In this sense, current situation in the accession process will be discussed in the following part. 


\subsubsection{Current Situation on the Accession Process}

Multilateral and bilateral negotiations are the most important and time-required stages in an accession process to the WTO. Thus, members of the organization join to the Working Party in order to pursue their own economic interests. In this sense, Paul Krugman stresses three basic "rules" of about the purpose of WTO members who join the negotiations: "exports are good", "imports are bad", "other things equal, an equal increase in imports and exports is good" (Bagwell and Staiger, 1999, pp. 225-226). Therefore, the countries in negotiations try to obtain the best conditions for their export in terms of the level of tariffs and government support of an acceding country to its domestic economy.

Azerbaijan's accession process also included the stage of multilateral and bilateral negotiations. After the third meeting of the Working Party on Azerbaijan, the negotiations were held on agriculture, services, tariffs, etc. However, the representatives from Azerbaijan stressed the concerns of Azerbaijan government about the development of non-oil sector and diversification of its economy at the sixth meeting of Working Party which strengthened Azerbaijan's hand in negotiations.

According to the official site for Azerbaijan's accession to WTO (www.wto.az), there are 37 participant countries in the Working Party. These are USA, European Union (EU), China, Canada, Argentina, Australia, Turkey, Brazil, Pakistan, Croatia, Dominican Republic, Ecuador, Egypt, Georgia, Haiti, Honduras, Norway, India, Japan, Jordan, Korea Republic, Ukraine, Kyrgyz Republic, Malaysia, Moldova, Nigeria, Oman, Panama, Paraguay, Philippines, Saudi Arabia, Sri Lanka, 
Switzerland, Taiwan, Tajikistan, Thailand and Viet Nam which EU participate as a custom union and represents the interests of its all members (27 countries).

Although the accession process has already lasted more than 16 years, a significant success is not achieved at the bilateral and multilateral negotiations between Azerbaijan and Working Party members. Thus, bilateral negotiations were only ended with Oman, United Arab Emirates (UAE), Turkey, Georgia and Kyrgyz Republic (bilateral protocols were signed) as well as China (CESD, 2013). However, bilateral negotiations still continue with remaining Working Party members, especially with USA, the EU, Canada and Australia as the main countries in world trade (CESD, 2013). Moreover, these countries are the most influential ones on the accession of a state to the organization. Although Russia joined to the WTO in August 2012, it has not yet joined to the Working Party on Azerbaijan's accession. However, Russia's joining to the working party is expected in the near future which has borders with Azerbaijan.

Obviously, Azerbaijan wants to get the membership status in WTO with favorable conditions as much as possible which clashes with the interests of other member states. Thus, Azerbaijan's initial offer for tariff negotiations is $14.4 \%$ on average and it aims to protect some crucial sectors of its economy through increasing tariffs on the import of relevant goods. On the other hand, it purposes to decrease the level of tariffs over the import of other goods in order to maintain the existing average tariff level. Tariff negotiations are separated into three categories such as agricultural products, non-agricultural products and sectoral initiatives. 
In this context, Azerbaijan offers $22.88 \%$ bound tariffs for agricultural products in average with $0 \%$ minimum and $80 \%$ maximum. However, Azerbaijan's offered average level of bound tariffs for agricultural products is higher than the level of corresponding tariffs of its neighbors such as Georgia (12.4\%) and Armenia (14.7\%) which are the members of WTO. Moreover, Azerbaijan offers higher bound tariffs (30-50\%) on import of many goods which are considered as crucial for its economy.

On the other hand, Azerbaijan's initial offer for bound tariff levels on nonagricultural products is $10.4 \%$ in average or more precisely, changes between $0 \%$ as the minimum and $50 \%$ as the maximum. Zero tariff level is defined for the import of raw materials or inputs for the domestic production. Average level of bound tariffs for non-agricultural products is also higher than Georgia (10.2\%) and Armenia (7.7\%). Here, it must be noted that the indicated tariff levels for both Georgia and Armenia are the levels of when they acceded to WTO. Thus, level of bound tariffs for both agricultural and non-agricultural products generally falls after the end of a defined time period.

In addition, tariff negotiations also include discussions on ensuring sectoral initiatives which purposes totally abolishing of tariffs or harmonizing of tariff levels in certain industry fields (ITA, 2013). Obviously, participation in sectoral initiatives is also an important issue on Azerbaijan's accession to the WTO. Thus, members of WTO, particularly USA and EU insists on joining of Azerbaijan to sectoral initiatives in some sectors at the high level such as information technologies, chemical harmonization, different kinds of equipment (construction, agricultural, medical, scientific) and etc. whereas Azerbaijan agrees to fully participate in the initiative only on agricultural equipment and partially on construction equipment 
(94\%), pharmaceutical preparations (93\%), scientific equipment (87\%), medical equipment (78\%), chemical harmonization (70\%), civil aviation (45\%) and information technologies (35\%).

On the other hand, WTO members, especially USA and EU demand from Azerbaijan to take commitment not to impose subsidies on the service sector, ensure the obtaining property rights over land for foreigners within Azerbaijan, increase the liberalization related to working of foreign specialists in Azerbaijan, provide nondiscriminatory conditions for foreign service suppliers, remove all king of restrictions over services as requirements of GATS etc. Negotiations on Azerbaijan's accession include also discussion on the technical barriers over trade in terms of mainly standardization and certification as well as harmonization of the legal basis for protection of intellectual property rights with the requirements of WTO.

To summarize the current situation in the accession process of Azerbaijan to the WTO, there is not a considerable progress during past sixteen years that bilateral negotiations are ended with only a few members of the Working Party. Moreover, some other countries such as Russia are expected to join to the Working Party on Azerbaijan which will require the start of bilateral negotiations with one more country. On the other hand, it seems that both Azerbaijan and WTO members insist on their own interests which make the accession more difficult. Therefore, there is less possibility for Azerbaijan to obtain WTO membership in near future. 


\subsubsection{Reasons behind Delaying of the Accession Process}

Despite of long-lasting accession process (more than sixteen years), Azerbaijan has not achieved to the membership status at the WTO. In addition, the accession process itself can not be considered as successful enough in light of this long time period. Several reasons may be specified as the cause delaying the membership. These can be both politically and economically rooted.

Sometimes, a country applies for the membership to WTO and this is followed by establishing a working party but, it does not implement the other required actions such as preparing and submitting the Memorandum or did this after a long time period which is known as "weak follow-up" as a usual case for the accession of countries in transition (Michalopoulos, 2000, p. 74). In this sense, although Azerbaijan applied for the membership to WTO in June 1997, it submitted the Memorandum on its Foreign Trade Regime in April 1999. Moreover, as we mentioned above there were serious problems related to the preparing required documents and answering the questions asked by the working party members on Azerbaijan in first years of the accession process. Thus, Azerbaijan ended submission of required documents to the WTO secretariat only in mid-2004 with the foreign assistance (Kavass, 2008, p. 360). Therefore, the main reason of delaying the accession process until 2004 should be considered as that Azerbaijan government was inexperienced in this kind of issues.

On the other hand, Nagorno-Karabakh conflict between Azerbaijan and Armenia is also considered as having an "indirect impact" on the accession process in terms of decreasing the scope of technical assistance from the members of WTO, creating sensitive questions as asked in the accession of Armenia and considering as a 
potential impediment for the congressional support for development (ESCAP, 2001, p. 112). Especially the last one is based on Jackson-Vanik amendment (section 907) which limits the support of USA to Azerbaijan (ESCAP, 2001, p. 112). In addition, sometimes, Armenia (a member of WTO) is considered as an obstacle for Azerbaijan's accession to WTO. However, Mahmoud Mammadguliyev who is Deputy Foreign Minister and Chief Negotiator on the accession process of Azerbaijan has stated that "Armenia has sent a letter stating that it would not oppose the entry of Azerbaijan in this organization" in time of its accession to WTO (Akhundov, 2012).

As we mentioned above, participants of multilateral and bilateral negotiations always pursue their own economic interests. In this sense, both Azerbaijan and other negotiator countries try to achieve the best outcome for themselves. That is why multilateral and bilateral negotiations require long time in order to get a conclusion. When we look through the meetings of the working party on Azerbaijan's accession, we find out that there are several major disputable economic issues such as the bound level of tariffs, government support to the agriculture, status of the membership, participation in sectoral initiatives, etc.

Azerbaijan insists to achieve the membership to WTO with developing country status which would ensure some concessions such as longer time period to implement all WTO commitments, special treatment while adopting rules in some fields like antidumping and technical barriers over trade, $10 \%$ de minimis opportunity to subsidize the agriculture sector, allowance to restrict the trade in order to solve balance of payments concerns and safeguard the external financial position (GATT, 
Article XII) and etc. Especially, agriculture is the main problematic field in negotiations.

More precisely, Azerbaijan intends to preserve government control over trade with other countries even after its accession to WTO. In addition, it insists on obtaining the highest de minimis level which would enable it to protect its agriculture sector from possible negative impacts of the accession. However, this represents the interests of Azerbaijan rather than all sides in negotiations that some countries, especially USA and EU insist on membership of Azerbaijan to WTO with developed country status as well as giving $5 \%$ de minimis level due to subsidize its own agriculture sector. In this sense, the success of negotiations is strongly related to the compromise of all sides which leads to the delaying of this accession process.

Another main issue in accession negotiations is related to the harmonization of Azerbaijan's legislation with WTO standards. Thus, M. Mammadguliyev had stated that "the second issue is of course the improvement of legislation to meet WTO standards. There are 40-50 documents, 30 of which have been approved in accordance with the organization's requirements" (CESD, 2012a). Moreover, some experts consider the monopoly and fear of integration in Azerbaijan economy and government as the main reasons behind delaying of this accession process but, these are only suppositions which have not any significant prove.

However, the impact of oil factor over the accession process is clearly understandable. As we mentioned above, Azerbaijan has stressed the oil dependence of its economy and especially export as well as diversification and development of non-oil economy issues. In addition, oil revenues gave opportunity to the government 
of Azerbaijan to finance $10 \%$ de minimis level in case of its obtaining in negotiations. Nevertheless, Azerbaijani economist V. Bayramov considers that "as long as the oil price remains high there is no incentive" for Azerbaijan's WTO membership (CESD, 2012b).

On the other hand, Turkish economist C. Bulut (2007) considers that increase of liberalization after each round of WTO negotiations makes the conditions more difficult for an applicant country that consequently, delaying of the accession process may increase possible difficulties (pp. 66-67). In addition, the accession of postSoviet countries to the WTO will also increase difficulties in Azerbaijan's accession process that obviously, those countries will also demand bilateral negotiations with Azerbaijan.

To sum up, various reasons may be specified as the cause of delaying the accession process of Azerbaijan to WTO. However, we discussed comparatively more important ones such as weak follow-up, Nagorno-Karabakh conflict, disagreement on membership status and the level of agricultural support, conformity of legislation with WTO standards, oil factor and time issue. In context of these reasons, it is expected that Azerbaijan's accession process will take some more years from the future. 


\section{Chapter 3}

\section{LITERATURE REVIEW}

WTO has been at the center of many scholars' interests. Thus, there are both proponents and opponents of WTO. In this sense, my research is focused on the impact of WTO on economic growth of developing countries. However, WTO is mostly about the trade and has an indirect impact over GDP which does this through affecting export and import of developing countries. The first main question is does the GATT/WTO matter for international trade? And the second one, if it matters what is the relationship between trade liberalization and economic growth in developing countries?

\subsection{Critiques toward GATT/WTO}

For the first time after creation of WTO, American economist Andrew K. Rose (2004a) did a systematic research about the impacts of GATT/WTO over the international trade. More precisely, he evaluated the impacts of multilateral trade agreements and Generalized System of Preferences (GSP) ensured for developing states by developed countries. In this research, he used "gravity model" of bilateral trade and employed the data of 50 years from 175 countries within a panel dataset. This research was focused on the effects of multilateral trade agreements while controlling standard factors as much as possible which affect the international trade such as culture, population, distance, language, location, area, colonial history and GSP status of countries. Moreover, he used natural logarithm of trade as the dependent variable. 
After taking into consideration of all these factors, he found out that increasing of trade is not related with GATT/WTO. If it would be the case, changes in trade of member countries should be "significantly different" from nonmember countries. As a result, he concludes that there is not "strong empirical evidence" yet to say "GATT/WTO has systematically played a strong role in encouraging trade". Nevertheless, his finding on the effects of GSP on trade had been significantly positive which increased the trade twice. In addition, Rose found out statistically and economically significant difference in the impacts of GATT/WTO in terms of rounds of negotiations. According to his findings, only initial one or two rounds of negotiations have had economically large impacts on international trade.

In another research, Rose (2004b) tested the hypotheses that whether GATT/WTO has increased stability and predictability in international trade or not. Again, he used the same dataset. At the same time, he employed the "conventional gravity model" of mutual trade among countries and the version of this model which he used to control many standard factors as well. This time, he defined the "coefficient of variation for the natural logarithm of real bilateral exports" as the dependent variable. As a result, he concluded that a state does not "experience more stable trade" after its accession to GATT/WTO in comparison with pre-accession period. However, it is not possible to test whether GATT/WTO stabilized international trade or not because of the data unavailability of before the creation of the GATT. Therefore, the hypothesis of this research "can not be rejected" but, the author also fails to find strong evidence in order to say that membership to GATT/WTO makes trade flows more predictable.

In his another article, Rose (2004c) studied the effect of GATT/WTO membership on trade policy liberalization. This time, he tries to find the answer of whether 
GATT/WTO membership is related with higher level of liberal trade policy or not. For this, he utilizes 68 different "measures of trade policy and liberalization". After all, he concluded that there is not significant correlation between trade policy measures and membership to the GATT/WTO. Thus, no reliable evidence was found to defend that GATT/WTO membership is related with more liberal trade policy. In this sense, his findings embodies that members and nonmembers of GATT/WTO do not substantially differ at tariff rates, non-tariff barriers, "price-based measures", "measures of openness" and etc.

On the other hand, J. Gowa and S. Y. Kim (2005) have studied the impacts of the GATT over international trade during 1950-1994. In their research, they find out that the impacts of GATT over trade had been "large", "positive" and "significant" for only the trade of USA, Britain, France, Canada and Germany. This implies that GATT had leaded to the increase only of a few states' trade. According to the authors, GATT changed the trade system of war period "de jure but not de facto" that trade patterns of postwar period have been affected by some interwar blocs as well. In this sense, the authors consider GATT as an attempt to increase the welfare of main countries in international trade instead of solving market-failure issues.

Walter G. Park (2009) has studied the impacts of WTO over distribution of trade, FDIs and patenting in developing and least developed countries in regard to their membership to WTO. He has classified developing and least developed countries in two groups - members and nonmembers of the WTO and make a comparison between these two groups. By using rank-sum tests, he found out that distribution of trade between developing country members and nonmembers of WTO had been 
“insignificantly different” (statistically) within 1996-1999 and significantly different within 2000-2003.

For least developed countries, the difference in distribution of trade between members and nonmember is always statistically insignificant within both time periods. On the other hand, the inflow and outflow of FDIs are found as "insignificantly different" among members and nonmembers of either developing or least developed countries. Moreover, the distribution of both resident and nonresident patent filings is also insignificantly different between members and nonmembers of both developing and least developed countries.

T. S. Eicher and C. Henn (2011) have also studied the impacts of WTO over international trade within a general approach through minimizing omitted variable biasedness. Thus, the authors stress the issue of omitted variable biasedness as the main cause of different results about the impact of WTO over international trade in previous researches. In this sense, they find out that WTO has not done a statistically significant impact on international trade transactions. In contrast with WTO, Preferential Trade Agreements (PTAs) impact trade strongly but unevenly.

Nevertheless, in case of addressing to special fields of trade which WTO may impact, it is concluded that membership to WTO increases trade until the creation of PTA among countries in less distance at the expense of international trade with other countries in long distance. Moreover, the impact of WTO is also depend on "termsof-trade" in time of the accession. Thus, countries which are more encouraged to negotiate decreasing of tariffs before the accession face with positive and significant impacts of WTO over its international trade after the accession. 
J. Roy (2011) has also conducted a research in order to study the impacts of WTO over international trade. Despite of previous research focused on solving Rose's "interesting mystery", the author claims that those researches fail to simultaneously address to the zero-trade problem trade "while controlling for the multilateral resistance terms". He employs the gravity with and without bilateral fixed effects which is regressed against log of real imports and bilateral trade data from 1950 to 2000. However, his findings do not support the claims about the significant role of WTO in trade promoting. Consequently, Roy states that "formal membership in the WTO is never found to increase bilateral trade".

In addition, J. Swinnen, A. Olper and T. Vandemoortele (2012) have conducted a research about the impact of WTO agreements over agricultural and food policies of members. As a result, they have found out a "significant shift from distortionary to less distortionary instruments" rather than a substantial fall in agricultural support in case of acceding to the organization.

\subsection{Supporters of the GATT/WTO System}

Rose's findings have been criticized by many scholars such as A. Subramanian, S-J. Wei, M. Tomz, J. L. Goldstein, D. Rivers and etc. Thus, Subramanian and Wei (2007) (hereafter SW) used a bilateral gravity trade model and the same data which Rose also used in his researches. Nevertheless, they added importer and exporter effects into their model and claimed that these would substantially alter the outcome of research which Rose's model does not include. Moreover, SW made one more significant change to the model used by Rose. Thus, they used a model regressed on imports instead of average real trade. As an outcome of this research, they found out 
that GATT/WTO has played a significant role in increasing of international trade but, this role has been "uneven" as a result of "asymmetries" within the system.

Thus, the effect of GATT/WTO membership has been higher in sectors where the impediments over trade are decreased in comparison with protected sectors. In addition, the new members of WTO (developing countries) have liberalized their trade much more than the old members as a result of negotiations with more countries during the accession process in comparison with old ones. Moreover, SW concludes that membership to GATT/WTO has increased the trade of developed countries primarily and strongly. According to $\mathrm{SW}$, this does not mean that “developing countries have not benefited from WTO membership". Empirical results indicate that imports of developing countries have been less affected by the membership to WTO. Nevertheless, developing countries have benefited from the trade liberalization in developed countries which their export to those countries has increased substantially with the impact of GATT/WTO.

However, M. Tomz, J. L. Goldstein and D. Rivers (2007a) (hereafter TGR) criticized both Rose and SW in terms of their classification of countries as members and nonmembers of GATT/WTO. Because Rose and SW use the same dataset in their research, TGR claim that they fail in defining of all participants of GATT/WTO. According to TGR, GATT established rights and commitments also for "colonies, newly independent states, and provisional members" as nonmember participants. Thus, considering them out of the system as done by Rose and SW understates GATT's impacts over trade. In this sense, they consider nonmember participants as part of the system in their model. In another article, they do an empirical research about this issue through using bilateral trade data after 1946 (Goldstein and Rivers, 
and Tomz, 2007b). After all, TGR find out the impact of GATT/WTO on international trade as positive and statistically and economically significant. They claim that all members of this system (developing countries as well) have benefited from the GATT/WTO.

C. Balding (2010) has also studied the impacts of WTO over the international trade. He uses the same data like Rose and SW but, define the imports as the dependent variable of his model in order to find out the effects of WTO membership on exporter and importer countries. Balding stresses that WTO affects "imports and exports differently" which is the cause of insignificant results in case of regressing against overall trade. According to the findings, increasing of both exports and imports are observed in only high-income countries whereas other countries face with "stagnant" or decreasing levels of trade. Moreover, trade substantially increases among member countries of WTO but, it decreases if one of the sides in international trade is a nonmember country.

General conclusion from Balding's research is that WTO membership affects trade "positively". Nevertheless, trade level of lesser develop countries doesnot rise with the effect of WTO membership. According to Balding, "joining to WTO is all about exports" that countries join to the organization in order to sell to the rest of the world rather than purchase from other countries. In this sense, the effect of WTO membership over exports is higher in comparison with its impacts over imports. Moreover, member countries export much more to nonmembers than their import from those countries. Therefore, WTO membership increases the exports to both members and nonmembers of the organization. 
X. Liu (2009) criticized the researches associated with the "ineffectiveness" of GATT/WTO in terms of increasing international trade. Thus, he claims that GATT/WTO also causes to changing the extensive margins of international trade through establishing new trade relations beyond affecting intensive margins of trade (existing trade relationships). Some of previous studies do not take into consideration the impacts of GATT/WTO on extensive margins of trade and this leads to the underestimation of GATT/WTO impacts. Moreover, he stresses the incapability of the traditional log-linear gravity model to work with heteroskedasticity issue and "non-normal residual" which causes to misestimating the impacts of GATT/WTO over intensive margins of trade as well. After all, the research ensures strong evidence about the effectiveness of GATT/WTO in promoting trade at both extensive margins of trade throughout the first five rounds of negotiations under GATT and intensive margins of trade especially after the creation of WTO. However, P. Dutt, T. V. Zandt and I. Mihov (2013) have found positive impact of WTO membership over extensive margin but, negative impact on intensive margin of trade.

Rose's finding about the effectiveness of GATT/WTO was criticized by L. Konya, L. Matyas and M. Harris (2011) as well. In their research, they use a new international dataset which enables to modeling the imports and exports respectively in order to analyze the extensive margin of trade. With the application of this dataset, they get positive results for the impacts of GATT/WTO over the international trade. Therefore, membership in GATT/WTO promotes international trade between member countries as well as member-nonmember countries. As the cause of Rose's negative results for the effectiveness of GATT/WTO, they stress not including the "zero bilateral trade observations" into his dataset. 
On the other hand, M. H. Kim (2008) criticizes Rose's finding in a different way. He argues that when the impact of this GATT/WTO was assessed, the researches should only focus on the trade in goods and sectors which are under the sphere of influence of this system. In this sense, he takes out the trade in agriculture, textile and oil from the evaluation within his research because of which those fields of trade are not regulated by GATT/WTO rules. Despite the exclusion of agriculture and textile (not oil) from the trade, the impacts of GATT/WTO over increasing of international trade become still insignificant. However, the impacts of GATT/WTO on trade become insignificantly positive in case of exclusion the oil trade from the evaluation as well. After all, he concludes that GATT/WTO has had significantly positive impact over the international trade in sectors which are under its sphere of the influence.

However, J. H. Grant and K.A. Boys (2012) study the exclusion of trade in agriculture through a large panel data on agricultural and nonagricultural international trade flows between countries from 1980 to 2004. The outcome of this research is that GATT/WTO promotes agricultural trade of member countries significantly (161\% on average) which is approximately twice of the GATT/WTO impact on nonagricultural trade of members. In this sense, middle and low income countries, who are interested in increasing agricultural exports, significantly benefit from the GATT/WTO membership. Moreover, including zero trade flows into the model enable to claim that membership in GATT/WTO does not just promote the existing trade relations or intensive margin of trade, it also causes to the establishment of new trade partnerships or promoting extensive margin of trade.

B. Herzl and M. Warner (2011) attempts to produce a "generalized approach" about the trade impacts of GATT/WTO through taking into consideration the findings of 
previous researches done by Rose, SW and TGR. Thus, they consider "de facto membership" as appropriate for many countries and influential for the effect of GATT/WTO membership. In order to cover the asymmetric impacts of mutual and non-mutual trade agreements, they define "unidirectional import flows" as the dependent variable in their research. Moreover, they also include zero trade flows into the evaluation which avoids neglecting extensive margin of international trade or biasedness of the estimation. As a result of "fixed-effect Poisson maximumlikelihood (PML) estimation", Herz1-Wagner find out that GATT/WTO promotes trade among members as well as with nonmembers. In this sense, they argue that the impact of GATT/WTO over the international trade of member countries is positive and statistically significant.

P. Chang and M. Lee (2011) study the impacts of GATT/WTO membership over bilateral trade among countries through application of "nonparametric methods" such as "pair-matching", "permutation tests" and "Rosenbaum sensitivity analysis". As a result, they find out that GATT/WTO significantly increases trade between members of the organization which is greater than the impact over trade between member and nonmember countries. Their conclusion remains the same in case of using participation status rather than formal membership as an indicator in the model. As response to Rose's negative findings about the impacts of GATT/WTO over international trade, they emphasize the misspecification issue in conventional gravity models especially in terms of homogeneous membership impacts assumption.

Although agriculture is not still taken under the control of GATT/WTO system, K. Anderson (2010) has studied the impact of WTO on trade distortions in this sector. Thus, he stresses the failure of GATT/WTO in avoiding the increase of protectionism 
in agriculture. In this sense, he emphasizes the importance of Doha round of negotiations that the agricultural protectionism may be increased much more in case of failing of this round. In case of removing protectionist policies over agriculture, the authors argue that the benefit of both farms and unskilled workers in agriculture sector would substantially, even seriously more than the comparative gain of nonagriculture sectors. Moreover, inequality and poverty would be reduced with these reforms.

E. D. Mansfield and E. Reinhardt (2008) have studied the impact of international institutions, especially WTO over the "volatility" of world commerce. They consider that countries join to international institutions such as the WTO in order to protect their economies from volatilities of international trade. In this context, authors hypothesize that those institutions decrease instability of the international trade. They use yearly export data for all bilateral relationships during the period from 1951 to 2001 for statistical tests and find out that WTO significantly decreases instability of exports which mean stabilizing of international trade.

M. Jansen (2010) emphasizes the importance of WTO in ensuring international standards in the world trade which causes to the decreasing of transaction costs. In addition, international standards are the essential policy measures to represent the quality of products to customers, including product safety. So that, WTO agreements cover rules about application of the standards due to prevent trade restrictions by member countries through imposing some kinds of measures. In addition, those agreements stimulate member countries to harmonize their standards or reciprocally recognize standards of other countries. Consequently, WTO agreements ensure 
opportunities for member countries to decrease transaction costs during the trade because of the differences in standards.

T. Buthe and H. V. Milner (2008) have studied the connection between FDI flow and GATT/WTO membership. According to the authors, joining to the organization ensures mechanisms for oversee capital owners to make obligations about the policies of an acceding country related to foreign assets. As a result, this causes to the increasing of investments in member countries. In this sense, international trade agreements create opportunities for developing countries to pull much more FDI which provide higher economic growth as well. More precisely, WTO membership raises the inflow of FDIs. This impact is still significant and positive even in case of taking domestic policy measures into consideration in the model. S. H. Shah, H. Hasnat and J. li (2010) have also found significantly positive impact of WTO over trade and inward FDI through statistical analysis in case of South Asian countries.

\subsection{WTO/Trade Liberalization and Economic Growth}

GATT/WTO membership is considered as the cause of liberalization in international trade by many scholars. T. L. Allee and J. E. Scalera (2012) claim that the impact of WTO accession is associated with the level of trade liberalization or obligations of acceding countries during the accession process. More precisely, the countries with higher level of commitments (policy changes) in terms of trade liberalization benefit much more from the WTO membership in comparison with member countries which less rigorously acceded (lower policy changes) to the organization. This conclusion derives from their classification of member states in WTO in terms of accession form such as "rigorous", "early" and "automatic" as well as doing an empirical research 
based on details of each country's accession process and commitments in time of accession.

The countries which acceded to the WTO at the end of a rigorous accession process (higher trade liberalization obligations) obtain substantial gains from trade after their membership. Early acceded countries also achieve higher level of trade after their membership in case of decreasing tariffs, significantly. However, not any evidence is available to say that trade increases in automatic joiners who acceded to the WTO without taking commitments to liberalize their trade.

In general, the relationship between trade liberalization and economic growth has been in interest of many scholars. Despite of huge amounts of studies, there are still some controversial points about the relationship. Some scholars have found the effect of international trade over economic growth as positive (Edwards, 1998; Frankel and Romer, 1996; Islam and Hye, and Shahbaz, 2012; Harrison, 1996; Winters, 2004). However, the definite relationship was not found yet because of some methodological and other kinds of reasons (He, 2011).

J. Lee (1995) stresses the importance of capital goods' for less developed countries which he considers to be helpful for the economic growth. More precisely, he claims that "relatively cheaper foreign capital goods, increases efficiency of capital accumulation" which fasters the economic growth in less developed countries. According to the author, any trade restrictions over capital goods' import harms long-run economic growth in those countries. 
According to K. Kiyota (2012), the impact of developing countries' trade liberalization on equality in those countries is also uncertain. On the basis of a "multiple-cone neoclassical growth model", Kiyota stresses that liberalization may increase "income inequality" and decrease "per capita GDP" if a country is globally labor abundant and locally capital abundant.

Moreover, D. Kim (2011) has used the "instrumental variable threshold regressions approach" in order to study the impact of trade liberalization over standard of living and long-run economic growth. His findings express that "greater trade openness tends to have strongly beneficial effects on growth and the standard of living of developed countries". However, international trade significantly negatively affects the "growth and real income" of less developed countries. According to Kim, trade affects economic performance of countries different channels such as "capital accumulation" and "productivity".

L. T. He (2011) has used "distributed lag models" in order to analyze short-term and long-term effects of international trade over GDP growth and inflation. The outcome of this analyze is that in case of huge accumulated trade deficit, trade significantly negatively impacts both economic growth and inflation which causes insignificantly negative impact over real GDP growth. In other words, if the current trade is not balanced, it negatively affects the GDP growth. That is why the author stresses the importance of a "strong trade policy" in order to encourage the GDP growth and avoid inflation in many cases. More precisely, international trade can increase economic productivity and decrease inflation. 
D-H. Kim and S-C. Lin (2009) have studied the impact of international trade over economic growth of countries at different development levels. They have used the "instrument-variable threshold regressions approach" in this research and find out that trade affects economic growth through both capital accumulation and productivity channels. More precisely, it affects investments negatively in lowincome countries and positively in high income countries. According to the findings, less developed countries tend to specialize in production of traditional goods in case of increasing trade openness. At the same time, developed countries specialize in production of goods which require high level of research and development.

In this sense, advanced economies benefits from trade in terms of its positive impact over investment and productivity while trade negatively affects both of them in less developed countries because of "technological or financial constraints" (Kim and Lin, 2009). The research done by S. Dowrick and J. Golley (2004) produces similar results about the distribution of trade benefits among countries. According to the authors, developed countries have got most part of trade benefit after 1980 and very small share has gone to less developed countries.

Moreover, the research done by A. Santos-Paulino and A. P. Thirlwall (2004) is also interesting in this context. They have studied the impact of trade liberalization over export, import as well as trade and current account balance of the balance of payments through including 22 developing countries from different regions of the world where substantial trade liberalization was observed after 1970s. They find out that exports and imports of developing countries are significantly affected by trade liberalization in terms of decreasing export and import duties. As a result, imports have increased much more than exports. According to the authors, trade 
liberalization has caused to the worsening of trade and current account balance of the balance of payments in developing countries.

In addition, negative impact of trade liberalization on export and positive impact on import is more in developing countries with higher level of protection before liberalizing the trade. In this sense, authors state that countries' balance of payments may be affected severely if import increase much more than exports with the impact of trade liberalization which can limit the economic growth of those countries as well. In his another research, A. Santos-Paulino (2005) stresses one more the issue of balance of trade and balance of payments in case of higher import growth after trade liberalization in developing countries.

Trade balance of a country represents if it is a "borrower" or "lender" in global capital markets (Gould and Ruffin, 1996). Thus, countries became a borrower in case of continuous trade deficits and vice versa. Gould and Ruffin (1996) also emphasizes the significance of international trade for the GDP growth through explaining basic form of GDP calculation (expenditure method):

$$
\mathrm{GDP}=\mathrm{C}+\mathrm{I}+\mathrm{G}+\mathrm{X}-\mathrm{M}
$$

Here, C-consumption, I-investment and G-government expenditures, X-export and M-import. Clearly, an increase in exports positively affects the GDP while import increase causes to the decreasing of it or has negative impact over GDP of a country. However, the gap/surplus of $(\mathrm{X}-\mathrm{M})$ is filled by the capital inflow/outflow. Consequently, the authors find "little" impact of "trade imbalances" over the GDP 
growth rates when basic determinants of the GDP growth are accounted for (Gould and Ruffin 1996).

Pacheco-López and Thirlwall (2007) have done a case study of Latin American countries (17 countries) in order to find out the impact of trade liberalization over the GDP growth. According to the authors, most of those countries have grown "faster, but at the expense of a deteriorating trade balance". Moreover, Chang, Kaltani and Loayza (2009) stress the importance of "complementary reforms" after trade liberalization in terms of gaining advantage in international competition. In an empirical research, they have found out that the impact of trade liberalization over economic growth can be "significantly improved" in case of undertaking a set of complementary reforms.

\subsection{Previous Researches on Azerbaijan's Case}

Although Azerbaijan's WTO accession has been continued since 1997, only a few researches have been done associated with its possible impacts over the economy of this country. Moreover, most of those researches do not include empirical estimations and econometrically assessed forecasting. More precisely, some scholars have only stressed possible positive and negative impacts of WTO accession just in "words" or theoretically based rather than producing an outcome through applying econometric models.

Thus, V. Bayramov (2008) has studied the impacts of WTO accession over Commonwealth of Independent States (CIS) which Azerbaijan is a member of CIS as well. As a result of comparative analysis of CIS country economies in terms, he has concluded that Azerbaijan's WTO accession will have positive impacts over struggle 
against corruption, reducing monopoly, increasing transparency and deepening economic integration. Nevertheless, accession to WTO is expected to negatively impact the "small producers, agriculture farmers and service sector".

\subsection{Limitations of Existing Research}

Most of the studies on the impact of WTO over economies of the member countries focus on the international trade impact as measured in total amount. More precisely, they do not usually look at export and import change separately in terms of studying the measurable impact of WTO membership on economic growth. In fact, I did not find any research which attempt to find out if the membership at WTO significantly affects the economic growth performance of member countries. In addition, many scholars do not take into consideration the impact of the time of membership which is an important point. Moreover, none of the researchers attempt to study the expected impacts of the membership for a nonmember country.

This thesis aims to resolve the last issue in case of Azerbaijan. Thus, the thesis will represent how macroeconomic indicators such as economic growth rate, export, import, net FDI flow, external debt/GDP ratio and gross capital formation in Azerbaijan economy are expected to changeif the country become a member of the WTO. The model will be based on Georgia and Armenia's macroeconomic performance before and after the WTO membership. In this sense, this thesis will also ensure empirical results for Georgia and Armenia, individually which will enable to discuss the effectiveness of WTO membership for these two country. 


\section{Chapter 4}

\section{GENERAL ECONOMIC OUTLOOK OF AZERBAIJAN, GEORGIA AND ARMENIA}

\subsection{Azerbaijan Economy in Transition Period: Historical and Graphical Interpretation}

The first years of independence had been much difficult for the Republic of Azerbaijan from both politic and economic sides. More precisely, economic problems were mainly the result of political changes in the country. Thus, the years 1991-1994 are named as the first period, recession period or regress period in economic development of Azerbaijan by different researchers. Unfortunately, this period of Azerbaijan economy has not been studied separately through identifying all causes of the economic decline. Here, we will discuss both political-economic and economic challenges for Azerbaijan within this period of its transition to market economy.

\subsubsection{Recession Period: 1991-1994}

Prior to independence, Azerbaijan was a part of the Soviet Union until 1991. During this period, economic system of the country was centrally planned (CPE). After regaining its independence, Azerbaijan targeted to transform its economic system toward market economy which required privatization and liberalization in all fields of the economy. However, Azerbaijan faced with serious political and economic recession during the initial years of the independence. 
In time of Soviet Union (SU), country's economic system was designed for the strategic requirements of the SU (Soyak and Nesirova, 2003, p. 3). Cultivation of lands was done collectively within massive production cooperatives and state farms which everything was under the control of administration (Lermana, 2000, p. 96). Despite of the independence, CPE still preserved its power in economy within the first period. Privatization could not be started because of political instability and ongoing war with Armenia. Moreover, the president of Azerbaijan was changed three times during the first three years of independence. The Communist party was in the administration yet and the first president of Azerbaijan (Ayaz Mutalibov) was "dependent" from the central government. He was unresponsive for the national problems and following Russia oriented policies (Yunusov, 2001, p. 62).

However, under the leadership of Abulfaz Elchibey or the Azerbaijan Popular Front Party (APF) after May 1992, the country's policy changed toward "nationalistic" Turkish oriented foreign policy which worsened conditions of the country in terms of economic pressure, done by Russia and Iran (Ismailzade, 2005, p. 2). In brief, the ongoing war between Azerbaijan and Armenia, loosing of territories, refugee and IDPs issue, instability of political regimes, transportation "embargo" of Russia, Chechen war and other political reasons caused deepening of the economic crises during this period of the transition (Kaynak and Nasirova, 2005, p. 40).

Moreover, collapse of Soviet Union caused to the destruction of economic ties with other post-Soviet countries, loosing of country's share in those markets and unavailability of subsidies from the central government (Suleymanov, 2008, p. 171). In addition, collapse of the "interrepublican trade arrangements" and delaying in 
"interrepublican payments systems" also leaded to the decline in production (Taymas, 1993).

According to the table 4.1, GDP of 1990 is approximately 2.67 times more than GDP volume of 1994. GDP growth rate in the first year of independence had been negative, but not in significant level. However, GDP had contracted $21.8 \%$ in average in other years of this period. Thus, added value in sectors of the economy in 1995 had decreased sharply in comparison with the corresponding indicators of 1990. Thus, agriculture was just $32.7 \%$ of the 1990 and respectively, manufacturing$77.5 \%$, industry- $64.5 \%$ and services- $64.3 \%$. On the other hand, total volume of export had decreased more than 2.32 times in 1994 in comparison with 1992 - \$1.484 billion (\$730 mln inter-republic and $\$ 754 \mathrm{mln}$ extra-republic export), mostly due to the decrease in export of oil \& gas and petroleum products (World Bank, 1995, p. 78).

Table 4.1. Change in main macroeconomic indicators: 1990-1994

\begin{tabular}{|c|c|c|c|c|c|c|}
\hline Indicators & Years & 1990 & 1991 & 1992 & 1993 & 1994 \\
\hline \multicolumn{2}{|c|}{ GDP (mln. USD) } & 8858.006 & 8792.366 & 4991.350 & 3973.027 & 3313.739 \\
\hline \multicolumn{2}{|c|}{ GDP growth (\%) } & - & -0.7 & -22.6 & -23.1 & -19.7 \\
\hline \multicolumn{2}{|c|}{ Inflation (\%) } & - & - & 46.2 & 1128 & 1662.2 \\
\hline
\end{tabular}

Source: World BankDatabase

Hyperinflation as the common issue of this period in most transition countries was observed in Azerbaijan also in the following years of price liberalization, 1992. Although the inflation rate was $46.2 \%$ in 1992 , it sharply increased to four digit numbers such as the $1662.2 \%$ in 1994. And the main cause of hyperinflation was 
compensation of budget deficits through money printing by Central Bank of the country (Kaynak, Nasirova, 2008, p. 41).

In 1993, a new president came to the government. After the regime change, the priority became to achieve the political stability and authority of central government over all events within Azerbaijan, under the control of new president - Heydar Aliyev. In this context, Azerbaijan and Armenia signed the cease-fire agreement in May 1994 which increased attractiveness of the country for the FDIs. Moreover, Azerbaijan invited foreign oil companies to invest to its oil sector that resulted by signing of the "Contract of Century" on $20^{\text {th }}$ September, 1994. This contract was valued as $\$ 60$ billion, including 33 companies of 15 different countries which enhanced Azerbaijan's place in FDI performance index to the top in following years (Bayulgen, 2003, p. 209).

To sum up, this period was characterized by sharp increase hyperinflation and decline in total output. However, establishing of National Bank and National currency should be considered as the welcoming events of this period. Anyway, initial conditions of the transition period for Azerbaijan were difficult to implement reforms for market economy. Consequently, Azerbaijan entered a new period of transition in 1995 with two crucial events: the cease-fire agreement and the "Contract of Century" which would take the country to a better place.

\subsubsection{Restructuring Period: 1995-2005}

The main target of the government after 1995 was to restructure the destructed economy with the effect of recession. Most of the scholars consider this period as lasted until 2003 because of the presidency change and new economic program toward social-economic development of Azerbaijan's regions. However, I suggest 
analyzing of this period until the end of 2005 as done in this research which is the year of opening Baku-Tbilisi-Ceyhan pipeline. In addition, 2005 is the turning point in Azerbaijan's economic development toward high speed economic growth and huge positive balance in current account.

Moreover, Azerbaijan started to implement radical economic policies in 1995 in collaboration with IMF under its comprehensive stabilization program due to prevent the hyperinflation issue (Baranick and Salayeva, 2005, p. 213).As a result,application of exchange rate based orthodox programs became very successful in Azerbaijan to reduce the inflation to one digit level within a short time period (Dabrowski, 2003, p. 17). At the same time, Azerbaijan accomplished to get credits from IMF only after implementation of IMF supported stabilization programs, in amount of \$219 million in December 20, 1996, especially for structural reforms (IMF, 1997, December).

In addition, adoption of Azerbaijan's constitution in November 12, 1995 was also significant event in terms of establishing juristic base for economic activities. Azerbaijan developed its cooperation with the World Bank and other international organizations that speeded restructuring of the economy as well. Thus, 31 World Bank projects with the value of $\$ 726.72 \mathrm{mln}$ in total had been carried out in Azerbaijan within this period of the transition (World Bank, 2013). However, occupation of $20 \%$ of its territory, the refugee and IDPs issue were still essential obstacles to restructuring of the economy. Thus, the country had lost a significant part of production potential as well as faced with additional unemployment issue in terms of refugees and IDPs. 
Oil industry was restructured within the "Contract of Century" in corporation with foreign oil companies. After achieving the stability, government launched reforms in economy toward establishing market economic system which required policy changes in macroeconomic stabilization, price and trade liberalization, privatization, supporting of new entrepreneurs, and development of a supportive juristic base (Aslund and Boone, and Johnson, 1996, p. 251). In context of such economic policies, government implemented reforms in agriculture such as distribution of land among private sector and privatization the property of old "Sovhozes" and "Kolhoses" (Thomas, 2006, p. 228).

However, the land area was distributed among households rather than establishing cooperatives in privatization process. In $2002,96 \%$ of "cultivated land" and $98 \%$ of "livestock inventories" were divided among individual farms and $80 \%$ of them did farming by themselves, just $1 / 10$ of total land was leased to others (Dudwicket al.,2007, p. 34). This kind of privatization and farming prevented establishment of cooperatives in agriculture which is required for the better performance in international competition.

In 1995, the parliament of Azerbaijan adopted the privatization program offered by the president which aimed to privatize $70 \%$ of state enterprises (World Bank, 2008, p. 15). Initially, small enterprises and later medium and large ones would be privatized through applying the voucher privatization method (World Bank, 2008, p. 15). Vouchers were distributed among Azerbaijani people that someone would buy them in order to private a state enterprise. According to the Transition Report 2005 of EBRD, the place of private sector in Azerbaijan's GDP for the mid of 2005 was $60 \%$. In addition, Azerbaijan's transition indicator scores (measurement between "1" 
and " $4+$ ") for 2005 became " 2 " in large-state privatization and competition policy, "4-" in small-state privatization, "4" in price liberalization and trade \& foreign exchange system (EBRD, 2005, pp. 3-4).

Table 4.2: Change in main macroeconomic indicators: 1995-2005

\begin{tabular}{|c|c|c|c|c|}
\hline & $\begin{array}{c}\text { GDP } \\
(\mathrm{mln} \text { \$) }\end{array}$ & $\begin{array}{c}\text { GDP } \\
\text { growth } \\
(\%)\end{array}$ & $\begin{array}{c}\text { Inflation } \\
(\%)\end{array}$ & $\begin{array}{c}\text { Current account } \\
\text { balance } \\
(\% \text { of GDP })\end{array}$ \\
\hline 1995 & 3052.4 & $-11,8$ & 411.75 & -13.12 \\
\hline 1996 & 3176.7 & 1,3 & 19.79 & -29.31 \\
\hline 1997 & 3962.7 & 5,8 & 3.67 & -23.11 \\
\hline 1998 & 4446.4 & 10 & -0.77 & -30.69 \\
\hline 1999 & 4581.2 & 7,4 & -8.52 & -13.09 \\
\hline 2000 & 5272.6 & 11,1 & 1.80 & -3.19 \\
\hline 2001 & 5707.6 & 9,9 & 1.54 & -0.91 \\
\hline 2002 & 6236.0 & 10,6 & 2.77 & -12.32 \\
\hline 2003 & 7275.7 & 11,2 & 2.23 & -27.77 \\
\hline 2004 & 8680.5 & 10,2 & 6.70 & -29.83 \\
\hline 2005 & 13245.4 & 26.4 & 9.67 & 1.26 \\
\hline
\end{tabular}

Source: World Bank, World Development Indicators

As a result of economic reforms and attracting FDIs to the oil sector of Azerbaijan, recession period was ended and positive economic growth (out of 1995) was observed. This represents itself in the economic indicators of that time as well. According to table 4.2, GDP had increased approximately 3 times in 2004 and 4 times in 2005 in comparison with the GDP of 1995. The inflation rate decreased to $411 \%$ in 1995 from $1662 \%$ of the previous year. Moreover, it decreased gradually until 2001 and even deflation was observed in 1998 and 1999.

As a result of liberalization in trade, the volume of import always exceeded the amount of export during this period. The proportion of current account deficit to GDP had been serious until 1998 or obtaining the first oil within "the Contract of 
Century”. However, this proportion had increased again after 2001, mainly because of the lower oil prices in world market that oil was the most important good in country's export. Moreover, the oil contract and implementation of economic reforms enhanced the attractiveness of Azerbaijan for FDIs.

In addition, according to World Bank Database, the added value had increased 1.57 times in agriculture, 2.44 times in manufacturing, 8.22 times in industry and 2.94 times in services in 2005 in comparison with 1995. However, the share of sectors in GDP had changed against agriculture (2.75 times), manufacturing (1.78 times) and services (1.32 times). In contrast, the share of industry in GDP had increased 1.89 times within the same time period mainly as a result of the increase in oil \& gas production. Thus, the share of oil \& gas had been $42.2 \%$ in GDP, $75 \%$ in industry, 86.5\% in total export and $94.2 \%$ in FDIs in 2005 (Ciarreta and Nasirov, 2012, p. 283).

After the 2003 elections for presidency of Azerbaijan, new president - Ilham Aliyev came to the government. He promised to create 600.000 new jobs within the next 5 years which had been approximately accomplished (Escudero, 2009, p. 10). In addition, the "State Program on Social-Economic Development of the Regions of Azerbaijan Republic for 2004-2008" was adopted which targeted to decrease the social-economic development gap among the regions of Azerbaijan as much as possible through supporting the regional developments, encouraging major sectors of the regions, producing of export-oriented products, ensuring new job opportunities etc (SPSEDR, 2004, pp. 3-4). Therefore, the new trend in historical development of Azerbaijan economy was not so far, especially related to the construction and 
opening of Baku-Tiblisi-Ceyhan pipeline as well as sharp increase in oil production under "the Contract of Century".

The evaluation of the restructuring period of Azerbaijan economy may be confused. Gaining stability in political environment supported the inflow of FDI and growth in economy. If only macroeconomic performance of the country would be analyzed, the evolution "score" would be very good. Nevertheless, the detailed analyze indicates that this "score" is highly related with the oil production, especially in 2005. Therefore, the oil-based development of Azerbaijan may cause additional negative effects for other sectors of economy what called as "Dutch Disease". Despite of oilbased development and the mistakes done in privatization, particularly in agriculture sector that still preserves its negative effects in terms of international competitiveness, the path from recession to this level of development under those conditions should be considered as a success. In addition, opening of BTC pipeline to use in May 2005 would take Azerbaijan to another period of economic development called as oil boom period.

\subsubsection{Oil Boom Period: After 2005}

Oil industry is not new for Azerbaijan economy that country was the biggest producer of oil in early twentieth century. In addition, Azerbaijan's rank in oil production through modern drilling equipments was at first in the $19^{\text {th }}$ century (Smith, 2001, p. 28). Although Azerbaijan started to produce its oil independently after the collapse of Soviet Union, there were significant problems in transportation and delivering of Azerbaijan oil to the world markets. That is why the oil boom in Azerbaijan started after opening of BTC pipeline that solved the issue we mentioned above. This pipeline was constructed to deliver Azerbaijan's oil to the Ceyhan 
seaport of Turkey through Georgia with $1760 \mathrm{~km}$ length and 1 million barrel/day export capacity (Cornell and Ismailzade, 2005, p. 61). In addition, the Baku-TbilisiErzurum (BTE) gas pipeline was constructed within 2004-2007 in order to deliver Azerbaijan's gas to Turkish and world market with 30 billion cubic meters gas export capacity (Aras and Suleymanov, 2012, p. 228).

Opening of BTC pipeline in 2005 sharply increased the oil production and exportation which means huge revenues from oil which substantially changed structure of the country's economy. Thus, oil production had been above 42 million tons after 2007 and even exceeded 50 billion tons in 2009 and 2010 but, in the subsequent years, production level fell and become 43 million tons in 2012 (SOCAR, 2013). As a result, Azerbaijan's GDP grew 34.5\% in 2006 and $25.05 \%$ in 2007. However, GDP growth slowed after 2007 which become just 1\% in 2011 because of the decline in oil production. Despite of the decline, Azerbaijan's economy grew $4.45 \%$ in 2012.

This period is also characterized by raising the importance of inflation issue in the country. Thus, the inflation increased and became in two digit numbers for the first time after 1996 which was the result of high-speed economic growth or over-heating of the economy associated with oil production. Revenues of the State Oil Fund of Azerbaijan Republic (SOFAZ) which was established to accumulate the revenues from oil \& gas production became $\$ 66.3$ billion within 2001-2011 where $\$ 64.1$ billion had been gained within 2005-2011 (SOFAZ, 2011, p. 11). And it is predicted to become $\$ 200$ billion until 2024 (Ciarreta and Nasirov, 2012, p. 282). Consequently, the huge amount of oil revenues leaded to the sharp increase in state 
budget or government expenditures through transfers from SOFAZ which raised the amount of national currency (manat) in circulation.

Table 4.3: Change in main macroeconomic indicators: 2006-2012

\begin{tabular}{|c|c|c|c|c|}
\hline & $\begin{array}{c}\text { GDP } \\
(\mathrm{mln} \$)\end{array}$ & $\begin{array}{c}\text { GDP } \\
\text { growth } \\
(\%)\end{array}$ & Inflation(\%) & $\begin{array}{c}\text { Current } \\
\text { account } \\
\text { balance } \\
(\% \text { of } \\
\text { GDP) }\end{array}$ \\
\hline 2006 & 20982.3 & 34.5 & 8.37 & 17.67 \\
\hline 2007 & 33049.4 & 25.05 & 16.6 & 27.3 \\
\hline 2008 & 48852.5 & 10.8 & 20.8 & 33.7 \\
\hline 2009 & 44291.5 & 9.3 & 1.4 & 22.97 \\
\hline 2010 & 52906.0 & 5 & 5.86 & 28.43 \\
\hline 2011 & 63403.7 & 1 & 7.85 & 27.04 \\
\hline 2012 & 67197.7 & 4.45 & 1.06 & 22.3 \\
\hline
\end{tabular}

Source: World Bank, World Development Indicators

In fact, the expenditures of state budget increased 7.2 times in comparison with 2005 which transfers from SOFAZ consisted $42.5 \%$ or $\$ 24,800.0$ mln of total sum of stated budget expenditures (\$58,317.8 mln) within 2006-2011(SOFAZ, 2011, p. 19). In addition, approximately $15 \%$ of state budget's own revenues were also related with oil and non-oil fiscal deficit became 32\% of GDP in 2012 (Boyarchuk, 2012, p. 2). As a result of sharp increase in oil export, current account balance became positive, even $33.7 \%$ of GDP in 2008 which the share of oil \& gas in gross export had been more than 90\% within 2006-2009 (Ciarreta and Nasirov, 2012, p. 283).

Distribution of value added GDP among sectors of the economy is also at the center of interest. According world development indicators (World Bank, 2013), the value added GDP, agriculture, industry and services become respectively 5.07, 3.2, 5.12 and 5.6 times of 2005 in 2011. Moreover, slight change was observed in proportional share of sectors in the country's GDP. Thus, the share of agriculture in value added 
GDP had decreased approximately from $9 \%$ in 2005 to $5.7 \%$ in 2012 . In contrast, the share of services has increased nearly from $24.4 \%$ in 2005 to $27.2 \%$ in 2012 . The change in share of industry is very little (less than one percent) but, it still dominates in the economy with $59.4 \%$ share in GDP.

Despite of high level of economic growth, there are still some crucial problems such as high level of oil dependence, economic diversification and less development of export oriented sectors of the economy. In addition, there is a disbalance distribution of labor force and GDP production among sectors of the economy as well as difference in labor force earnings regard to this disbalance. Thus, only $1 \%$ of the total labor force is employed in oil and gas industries and 50\% in agriculture (Ciarreta and Nasirov, 2012, p. 283). This implies that 50\% of total labor force produces very small share $(5.7 \%)$ of GDP while $1 \%$ does a significant part. Obviously, this is embodied in salary of workers in different sectors as well.

To sum up, Azerbaijan's economic development in this period was mostly related to the sharp increase in oil production. At first sight, the macroeconomic performance may be considered as very good. However, some problems are remaining in its economy. Decreasing oil \& gas dependence and disbalance among sectors of economy as well as establishing a diversified economy with strong export oriented industry could take Azerbaijan a better place.

\subsubsection{Graphical Interpretation}

Republic of Azerbaijan is the largest country of its region (South Caucasus) in terms of territory, population and economic power. It enjoys favorable geographical location as at the crossroads of Asia and Europe and surrounded by Russia on the North, Iran on the South, Georgia on the North-West, Armenia on the West, Turkey 
on the North-West and Caspian Sea on the East. In addition, it has sea borders with Russia, Iran, Kazakhstan and Turkmenistan as well. Although internationally recognized territory of Azerbaijan is 86.6 thousand square kilometers, $20 \%$ of this is occupied by the Republic of Armenia in 1992-1993. Its population is about 9.4 million which approximately, one million are refugees and IDPs as a result of military conflict with Armenia. The country is rich of natural resources, especially, oil and gas. Moreover, Azerbaijan has great potential for agriculture sector and development of tourism in terms of climate conditions.

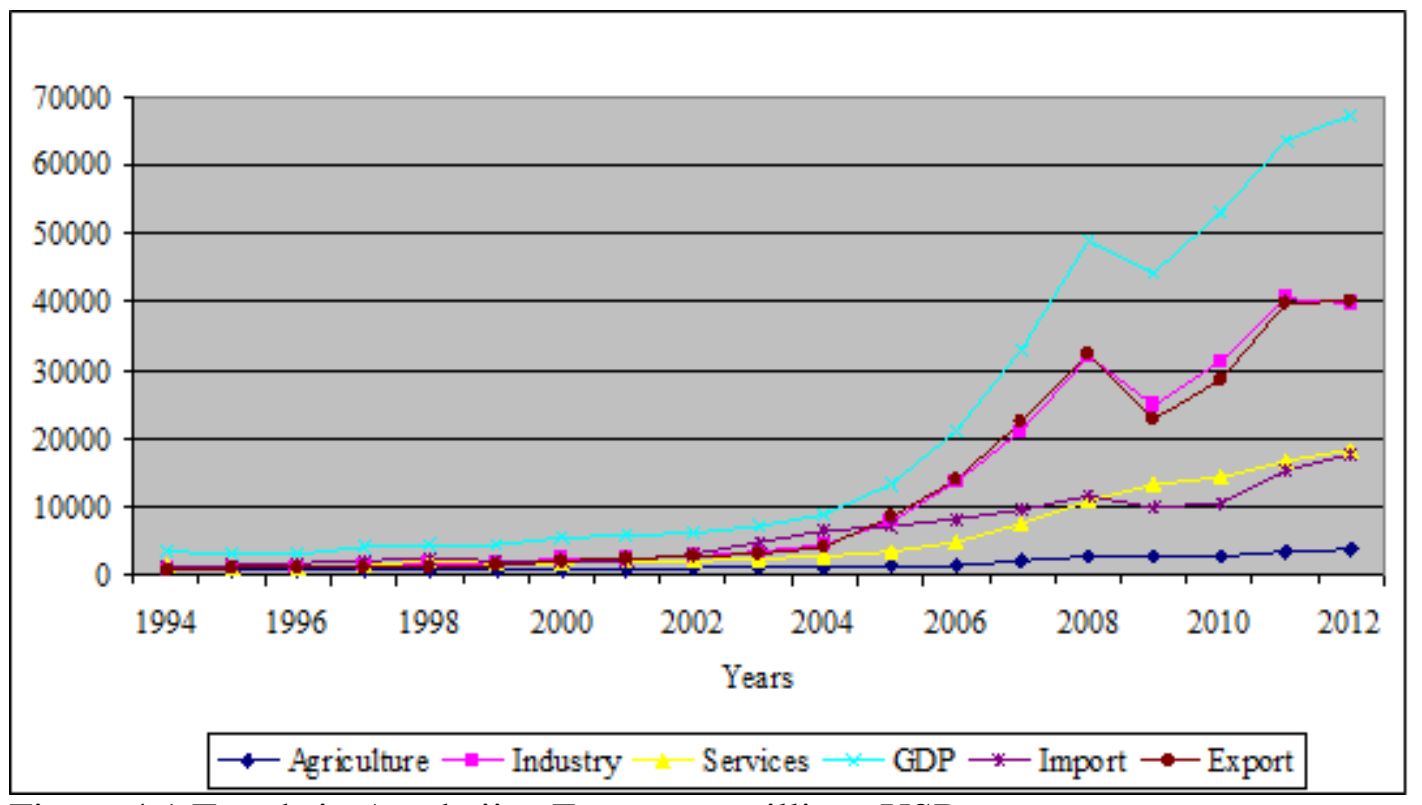

Figure 4.1 Trends in Azerbaijan Economy, millions USD

All information given above is targeted to create an impression in mind of readers about the Republic of Azerbaijan and under which conditions economic development of the country was achieved. Here, we will graphically discuss the trend in GDP and its components after the end of economic recession, 1994. We will analyze the changes in GDP and GDP components of Azerbaijan economy in two ways: including and excluding contribution of oil \& gas sector to the GDP, industry and export of the country. 
Figure 4.1 indicates the value of GDP and GDP components in USD which embodies the impact of oil \& gas sector as well. From the graph, it is clear that not a substantial change was observed in both GDP trend and trends in its components until 2004. However, because of opening the Baku-Tbilisi-Ceyhan (BTC) pipeline in May 2005, sharp increase in both GDP and industry sector was seen until 2008.

Increasing of oil prices has also affected positively GDP value and industrial production. Thus, oil price for per barrel increased from $\$ 50$ in 2007 to $\$ 140$ in summer of 2008 which fell to $\$ 40$ at the end of the same year (Smith, 2009). That is why Azerbaijan's GDP raised approximately \$16 billion in 2008 which was mainly sourced from the increase in industrial, more precisely oil production. However, a decrease in GDP and industrial production was observed in 2009 as a result of sharp fall in oil prices and 2008 Financial Crises in the world economy. After 2009, the amount both GDP and industrial production significantly increased. Nevertheless, industrial production decreased slightly after 2011 mainly because of the fall in amount of oil production.

On the other hand, no volatility was observed in amount of both agricultural and service production during the whole period. Thus, change in agriculture sector has been very small in comparison with the GDP growth. However, added value in service sector has also substantially risen as parallel to the increase in GDP after 2005. Hence, added value in service sector has exceeded $\$ 18$ billion in 2012 which is 5.6 times of the corresponding value in 2005 .

The export trend is almost on the same line with industry trend because of the oil factor. The country has had also increasing import trend, especially after 2005 
(declined only in 2009). Very huge trade surplus was observed after 2005 which reached to $\$ 20$ billion in 2008 and $\$ 22$ billion in 2012, mainly because of the oil export.

Although Azerbaijan economy was characterized with high speed economic growth until recent years, the growth itself has been at the center of discussions along the period, especially after 2005 in terms of the dependency from oil sector. In Figure 4.2, we have attempted to analyze the GDP, industry and export trends in Azerbaijan economy, with and without contribution of oil \& gas.

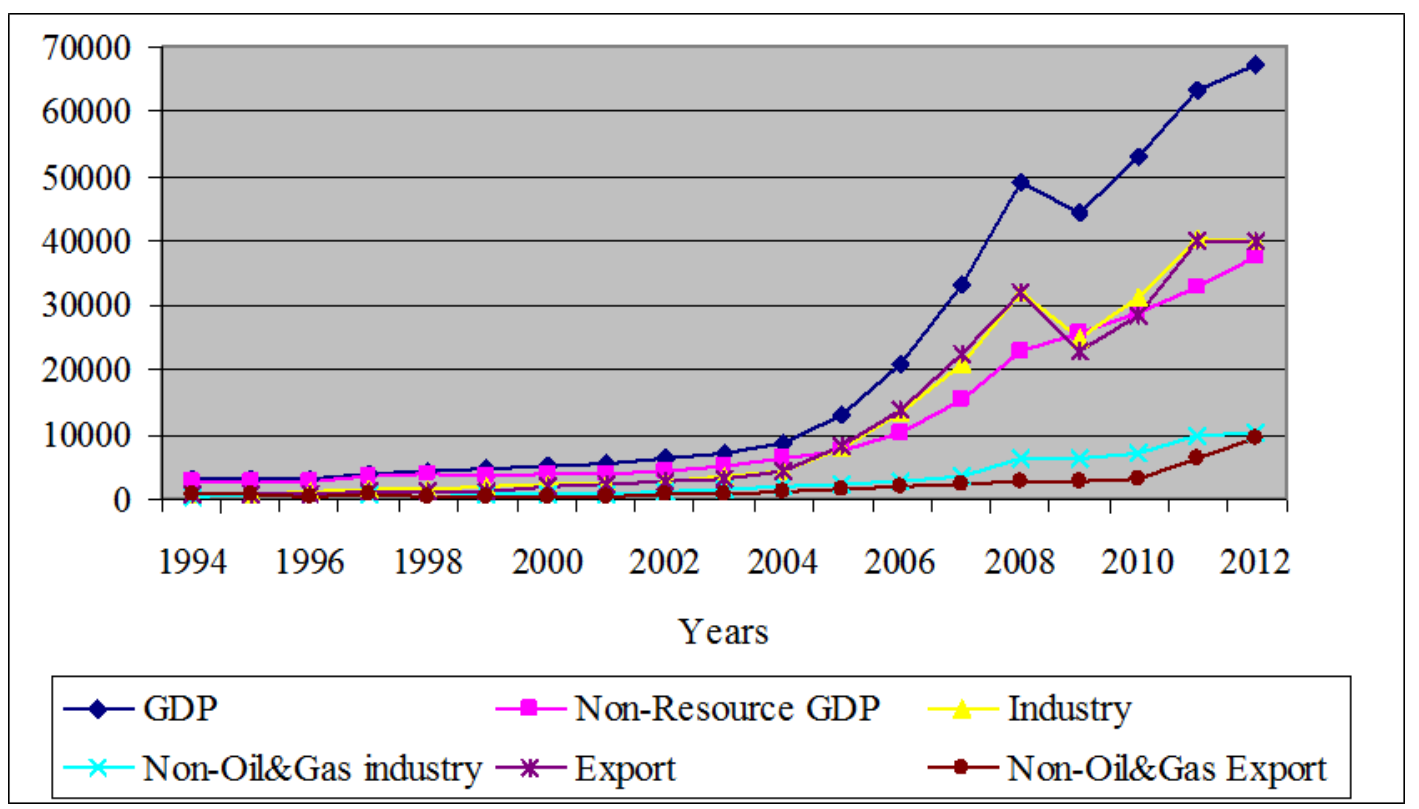

Figure 4.2 Comparative trends in Azerbaijan's GDP and GDP components, millions USD

Comparative trends indicate that normal and non-oil \& gas GDP do not differ so much until 2005. However, sharp increase in oil production after 2005 has leaded to the expansion of the gap. In 2008, the gap exceeded $\$ 25$ billion which achieved to 
$\$ 31$ billion in 2011. This was represented in industrial production (mining industry) and exports of the country as well.

Thus, the gap between industrial production with and without oil \& gas also significantly increased after 2005 which became $\$ 26$ billion in 2008 and $\$ 30$ billion in 2011. As a result, the share of oil \& gas production in industry has been $70-80 \%$ which is considerable very high. In export, the situation is much more crucial. Thus, share of oil and gas in total export has been over $70 \%$ after 2000 and between 82 $91 \%$ in $2005-2011$.

Nevertheless, all these were already expected in context of the "Contract of the Century" many years ago. More important question is what kind of non-oil \& gas trends were observed within this period. According to Figure 4.2, non-oil \& gas GDP has also grew substantially after 2005. Thus, its value in 2012 is 5 times of in 2005 . Approximately the same result is also belonging to the change in value of non-oil $\&$ gas industry within 2005-2012. Moreover, total volume of non-oil-and-gas export has also increased 6.7 times (2012) in comparison with 2005.

On the other hand, the amount of gross capital formation or gross domestic investments has had an upward trend during the almost whole period. According to World Bank Database, yearly gross capital formation had increased from $\$ 0.5$ billion in 1994 to $\$ 5.5$ billion in 2005 and nearly $\$ 13$ billion in 2012. Moreover, the positive trend in net FDI flow to the country was also observed during the period. Thus, net FDI flow had risen from less than $\$ 93$ million to approximately $\$ 4.5$ billion in 2005 and $\$ 5.3$ billion in 2012. However, positive trends in Azerbaijan economy were 
accompanied with the increasing of external debt stocks of the country. Thus, Azerbaijan's external debt reached to \$2.2 billion in 2005 and \$7.6 billion in 2012 .

Figure 4.3 represents the trend in gross capital formation, net FDI flow and accumulation of external debt in Azerbaijan economy.

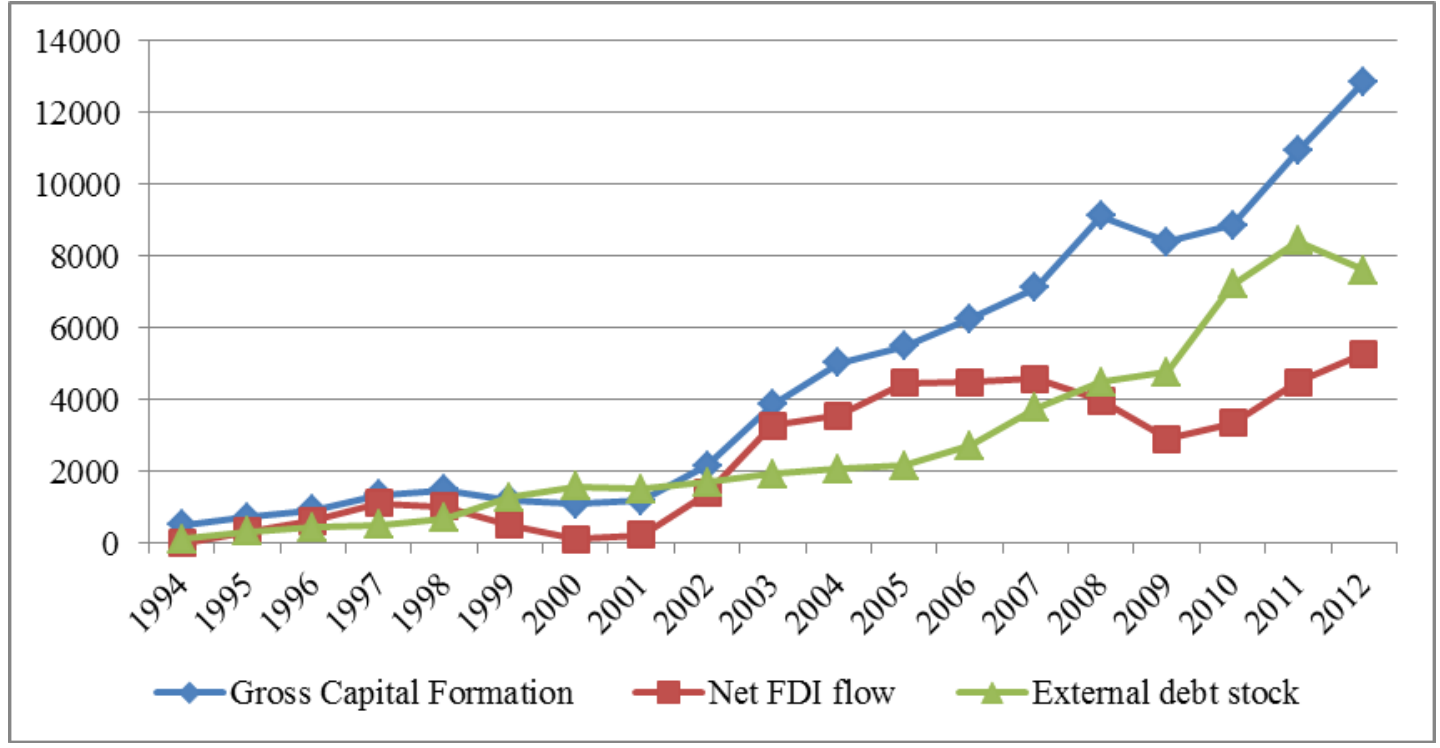

Figure 4.3 Trends in Azerbaijan Economy, millions USD

All non-oil \& gas trends have slow-speed increasing tendency during the whole period. This proves that non-oil \& gas sector did not decline in parallel with oil production. However, this should not be considered as that other sectors have not been affected by sharp increase in oil production and following huge revenues. Nevertheless, any research about Azerbaijan economy should take into consideration the occupation fact of its $1 / 5^{\text {th }}$ territory and living in military conditions. 


\subsection{General Outlook of Georgia economy}

Georgia is the another country of South Caucasus region which has borders with Azerbaijan in the southeast, Turkey and Armenia in the south, Russia in the north and surrounded by the Black Sea in the west. It is the only country of the region with direct access to the world ocean. With 69.7 thousand square kilometers territory and 4.7 million populations, it is the second biggest country in the South Caucasus. The shortest way from Asia to Europe passes through the country. As a result, Georgia enjoys of main regional projects related to delivering of Azerbaijan oil and gas resources to the European market. After gaining independence, Georgia faced with Abkhazian and Ossetian ethnic conflicts within its territory. Georgia's last military attempt to solve these conflicts in August 2008 caused to the five-day RussiaGeorgia war which seriously destructed Georgia's economy. Here, we will analyze trends in GDP and GDP components as well as export and import of Georgia before and after its accession to WTO (June, 2000).

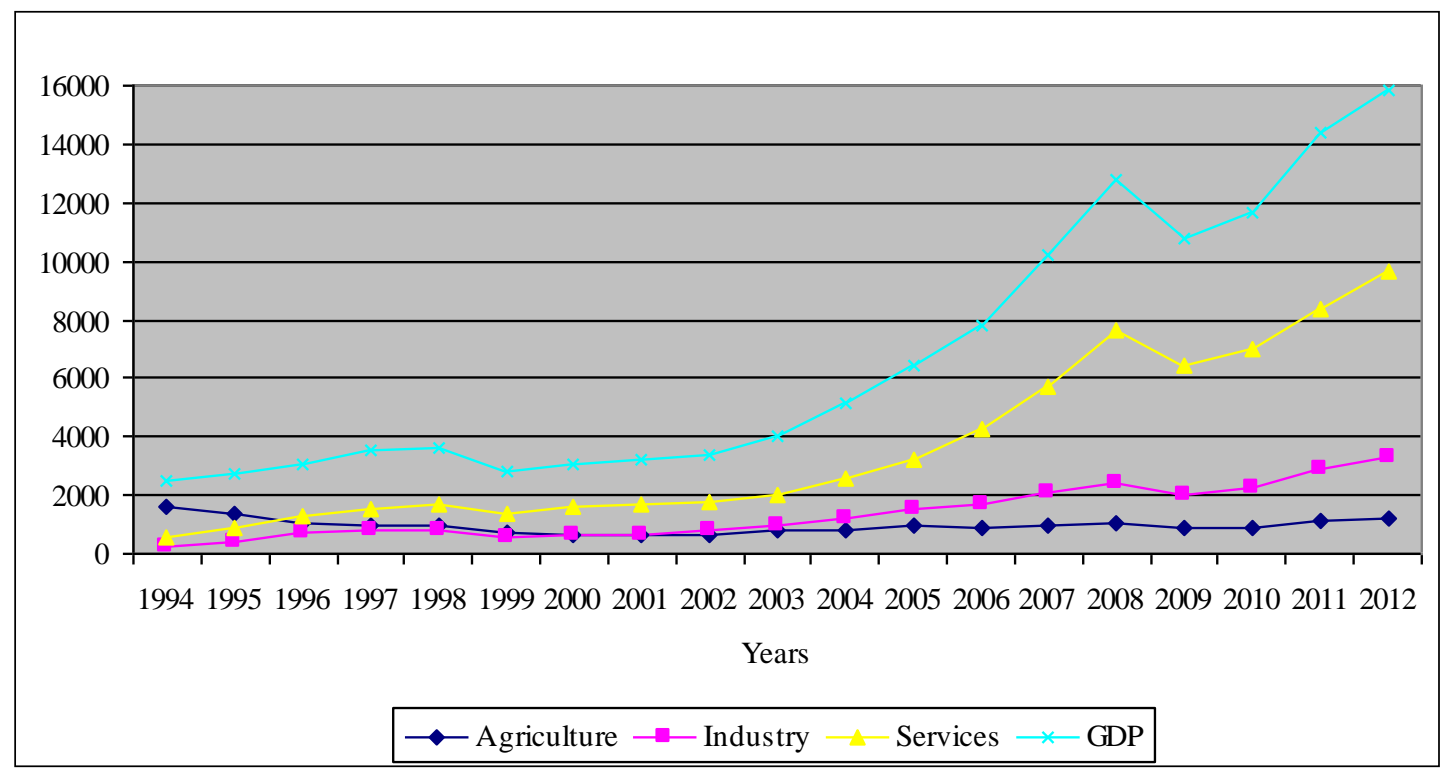

Figure 4.4 Trends in Georgia's GDP and GDP components, million USD 
Figure 4.4 represents the changes in GDP and GDP components of Georgia in terms of added value regard to the sectors. It is clear that Georgian economy has grown until 1998. In the subsequent year, a decline was observed in GDP of Georgia. However, this decline was followed by slow economic growth until 2003. During the period, agricultural production has decreased whereas the share of service sector in GDP has gradually increased. Despite of very small fluctuations, neither agriculture nor industry significantly changed until 2003.

According to the Figure 4.4, Georgian membership in WTO did not cause any significant increase in GDP production in subsequent years of the accession. When we compare GDP indicators and sectoral production before and after 2000, not any significant change is observed with the impact of accession in all sectors until 2003. The year of 2003 was written to the history of Georgia because of the "Rose Revolution" which followed by increasing democracy, decreasing corruption and developing of the country's economy (Papava, 2009, p. 199). As a result, Georgian GDP also substantially increased in the following years which exceeded $\$ 6$ billion in 2005 and grew approximately \$2 billion each year until the end of 2008 . 


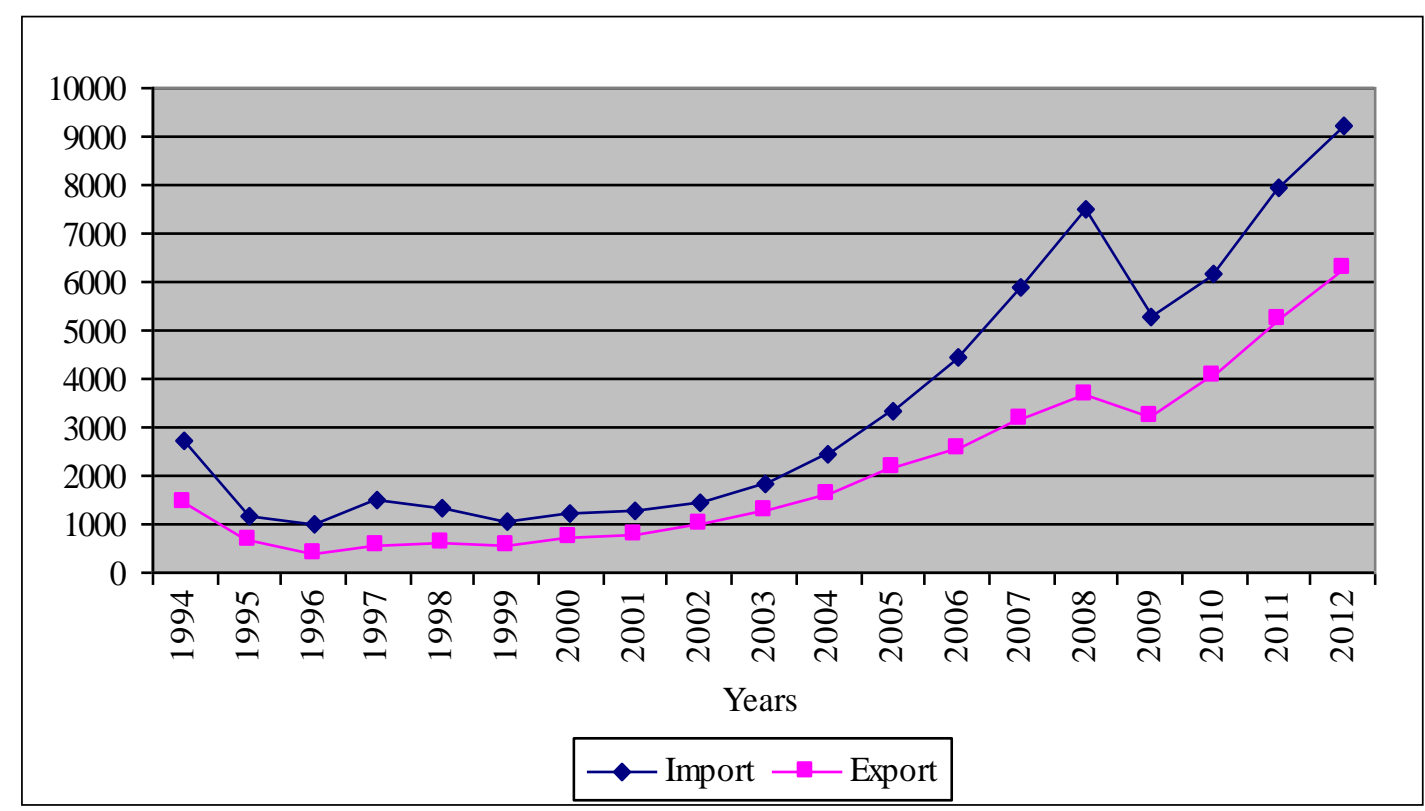

Figure 4.5 Trends in Georgia's international trade, millions USD

However, the economy declined in 2009 , most probably due to the effect of Financial Crises of 2008 in world economy. Interestingly, this decline was the result of fall mainly in service and partially in industrial production. Nevertheless, the economy recovered and grew in subsequent years and reached to nearly \$16 billion in 2012 . The notable point here is that this economic growth was mostly sourced from the increase in service production rather than overall development of the economy.

In fact, agricultural production did not change significantly during all period, even decreased in some years. During the same period, its share in GDP fell from 19.3\% in 2003 to $7.6 \%$ in 2012. However, agriculture is still a crucial sector in Georgian economy which employees $50 \%$ of the country's population (World Bank). Another serious point is achieving of this level of economic growth as parallel to the significantly increasing of budget expenses and government debt (Guruli, 2012). Thus, foreign debt of Georgia in total has increased three times within 2006-2010 from $\$ 3.8$ billion to $\$ 9.8$ billion which exceeded $\$ 11$ billion in 2011(Staff, 2012). 
It is interesting that foreign trade balance of Georgia has been always negative (Figure 4.5). In initial years of its independence, both import and had significantly declined with the effect of economic recession after the collapse of Soviet Union. In subsequent years, export of the country has never substantially increased and became always lower than $\$ 1$ billion before the accession. On the other hand, despite of an increase in amount of imports in 1997 which reached to nearly $\$ 1.5$ billion, it decreased and become slightly more than $\$ 1$ billion in the pre-accession year. However, both export and import of the country increased after the accession, approximately in the same amount until the end of 2003 or the Rose Revolution in Georgia.

After 2003, import of Georgia increased much more than its exports which expanded its trade deficit. Moreover, this yearly deficit also substantially increased every year. Especially after the year of 2005, trade deficit of the country exceeded $\$ 1$ billion which reached to nearly $\$ 4$ billion in 2008. Georgia's import fell sharply in 2009 in comparison with slight decrease in amount of export. However, it still preserve at least \$2 billion deficit which increased in the following years and become approximately $\$ 3$ billion in 2012. Doubtless, after the end of transitional period for application of WTO commitments (2005), Georgia's international trade significantly increased. But, this positive impact became considerable higher over imports in comparison with exports. 


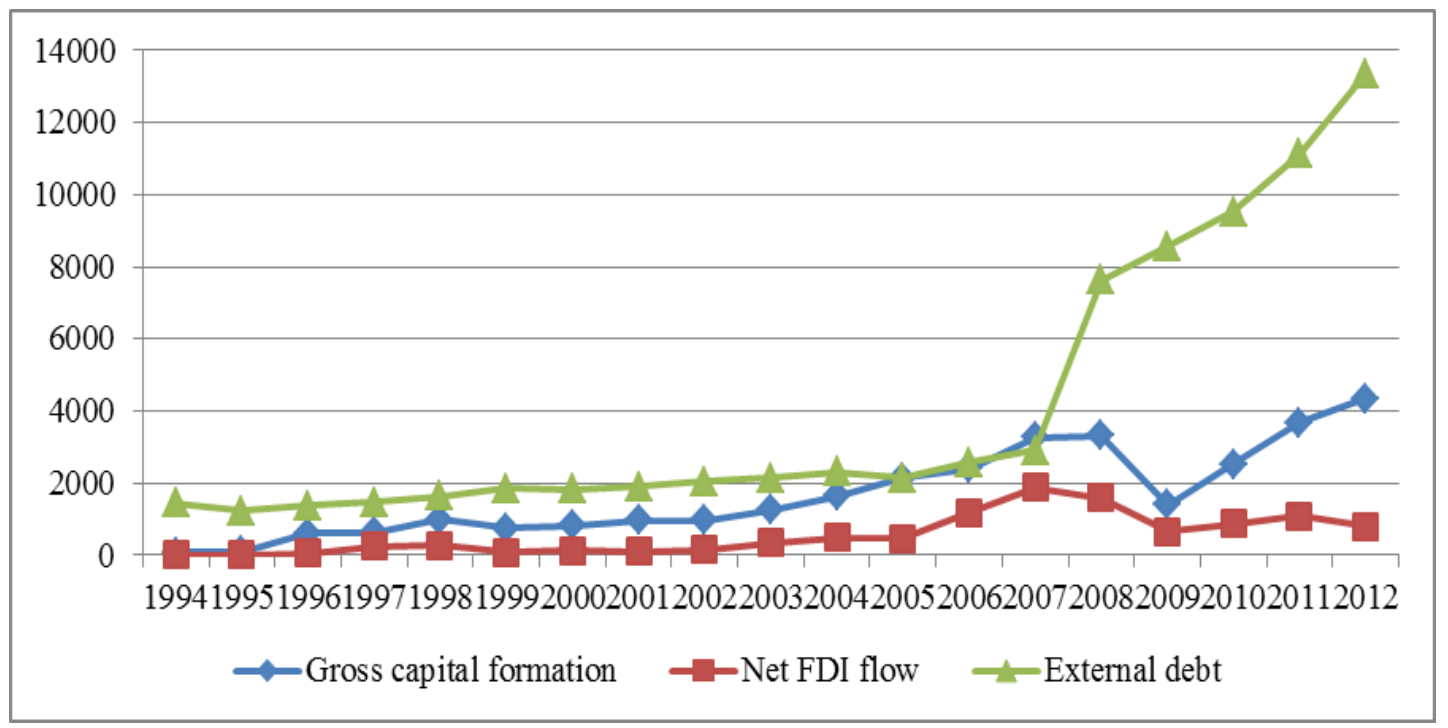

Figure 4.6 Trends in Georgia's economy, millions USD

Moreover, the changes in Georgia's gross capital formation, net FDI flow and external debt stocks before and after WTO accession are also interesting. According to World Bank database, gross capital formation or gross domestic investments had an increasing trend and reached to $\$ 0.81$ billion before the accession year. In first years of its membership, gross capital did not exceed $\$ 1$ billion as well. Only after the Rose Revaluation in 2003, it significantly increased and become more than $\$ 3.3$ billion in 2008, before the Financial Crises. Although it sharply fell to $\$ 1.4$ billion in 2009, it recovered and reached to $\$ 4.3$ billion in 2012 .

For the net FDI flow of Georgia, the trend seriously fluctuates. Thus, the amount of net FDI had been very few or less than $\$ 250$ million until 2003. It exceeds $\$ 1$ billion only in 2006-2008 which sharply falls to $\$ 0.65$ billion in 2009 . Although the amount of net FDI become more than $\$ 1$ billion in 2011 again, it can not stay at this level and fall to $\$ 0.8$ billion in 2012. On the other hand, the amount of Georgia's external debt stocks had been lower than $\$ 2$ billion before the WTO accession and around until 2005. However, Georgia's external debt stock increased sharply after 2005, 
especially in 2008 from $\$ 2.9$ billion to $\$ 7.63$ billion. By the end of 2012, Georgia's external debt stock had been more than $\$ 13.3$ billion (CIA, 2013).

As a result, the impact of WTO accession on Georgia's GDP, GDP components and international trade should not be considered as only positive. Although the economy grew every year (excluding 2009), this growth was not the consequence of production increase in all sectors of the economy. In addition, it is questionable that how much the WTO membership has impact over the economic growth in terms of spurious regression possibility. Moreover, increasing of the trade deficit as well as foreign debt of the country implies possibility of serious economic problems in the future.

\subsection{General Outlook of Armenia Economy}

Armenia is the last country, situated in South Caucasus region with 29.7 thousand square kilometers territory and nearly 3 million populations. It is a land-locked country which surrounded by Georgia on the north, Iran on the south, Turkey on the west and Azerbaijan on the east. However, the borders of Armenia with Turkey and Azerbaijan are blocked due to the Nagorno-Karabakh conflict between Azerbaijan and Armenia. As a result, this has left it out of main regional projects and heavily damaged its economy. 


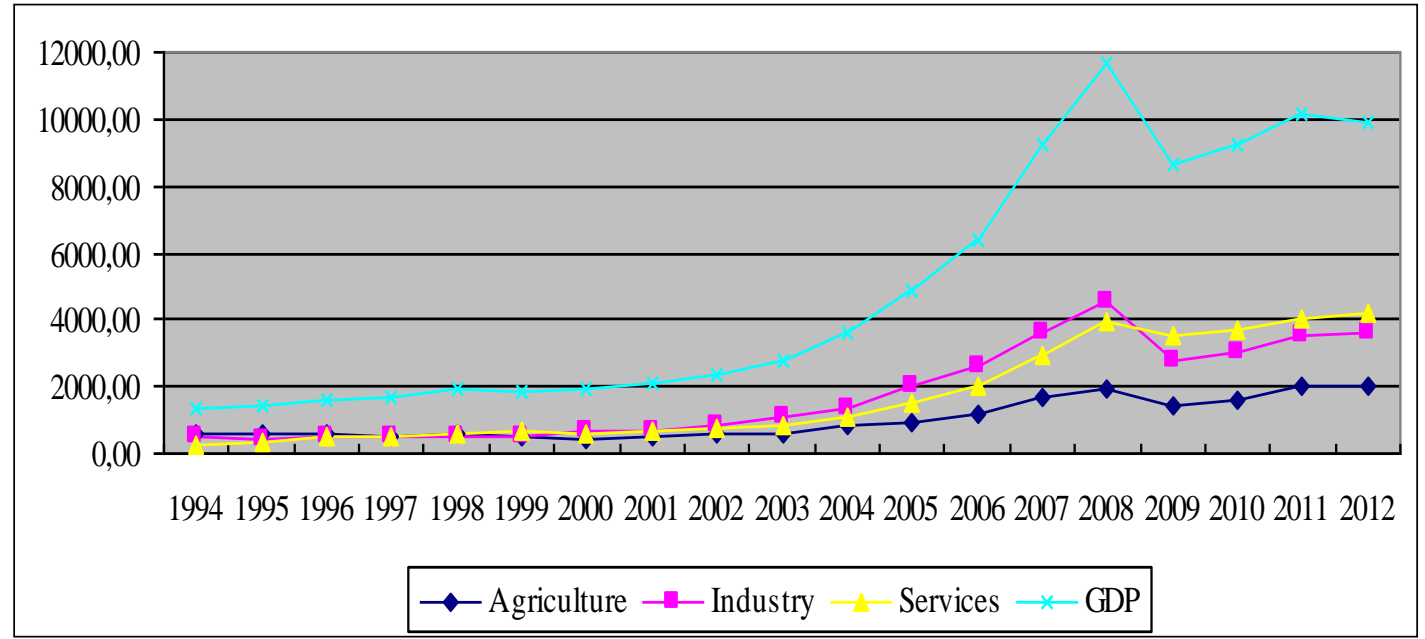

Figure 4.7 Trends in Armenia's GDP and GDP components, millions USD

The country has also faced with economic recession in first years of its independence. However, the recession was handled with the foreign support before 1994. Figure 4.7 represents the trends in Armenia's GDP and GDP components after 1994. The graph indicates that Armenia's GDP has slightly increased within 19942002 which exceeded the value of $\$ 2$ billion only in 2001 despite of a seven year time period. Nevertheless, a relatively sharp increase is observed after 2003 which is also the accession year of Armenia to WTO. According to the World Bank data, the country's GDP grew in double-digit percentage until 2009. Its GDP reached to the highest level - \$11.6 billion in 2008. However, Armenia's economy declined and fell to $\$ 8.6$ billion in 2009 . In following years, the economy was recovered and positive growth was observed until 2012. Hence, its GDP decreased again and recorded under \$10 billion in 2012.

In context of GDP distribution among sectors of economy, no significant differences in amount of sectoral production was observed until 2003. However, sectoral production grew much more in industry and service sectors after 2003 and economy became industry dominated until 2009. With the effect of the world financial crises, 
industry declined much more than other sectors in 2009 and lost its dominance. As a result, service sector gain the dominance in subsequent years of GDP. On the other hand, agricultural production slightly changed during the whole period which reached to $\$ 1.9$ billion in 2008 , fell to $\$ 1.46$ billion in 2009 and re-increased in following years but, never exceeded the value of $\$ 2$ billion.

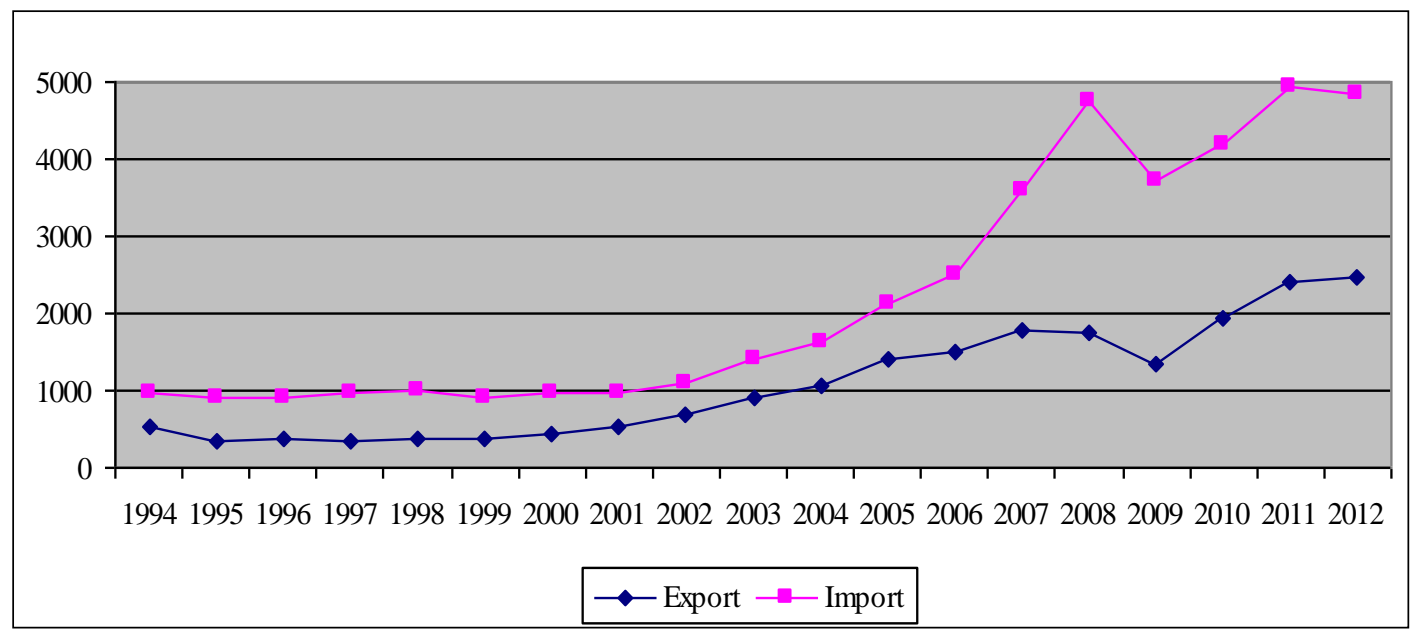

Figure 4.8 Trends in Armenia's international trade, millions USD

The trends in export and import of Armenia before and after its accession to WTO are also interesting. These trends are indicated in Figure 4.8. It is observed that Armenia has always faced with deficits in foreign trade during the whole period, in both before and after its WTO accession. In addition, the amount of both export and import of the country had been mainly about or under $\$ 1$ billion until 2003. After 2003 or its WTO accession, imports of the country increased much more in comparison with its exports. Especially, imports increased sharply after 2005 and trade deficit reached to nearly $\$ 3$ billion in 2008. Although this deficit decreased in the subsequent years, it was still observed above $\$ 2$ billion.

Obviously, Armenia's accession to WTO promoted its imports considerable much more than its exports which might not be considered as a good impact in Armenia's 
perspective. Interestingly, both highest level of GDP and trade deficit of Armenia were observed in 2008. On the other hand, continuous deficit in foreign trade might increase the foreign debt of the country. However, "Armenia's severe trade imbalance has been offset somewhat by international aid, remittances from Armenians working abroad, and foreign direct investment" and "Armenia is particularly dependent on Russian commercial and governmental support" (http://www.indexmundi.com/armenia/economy_profile.html).

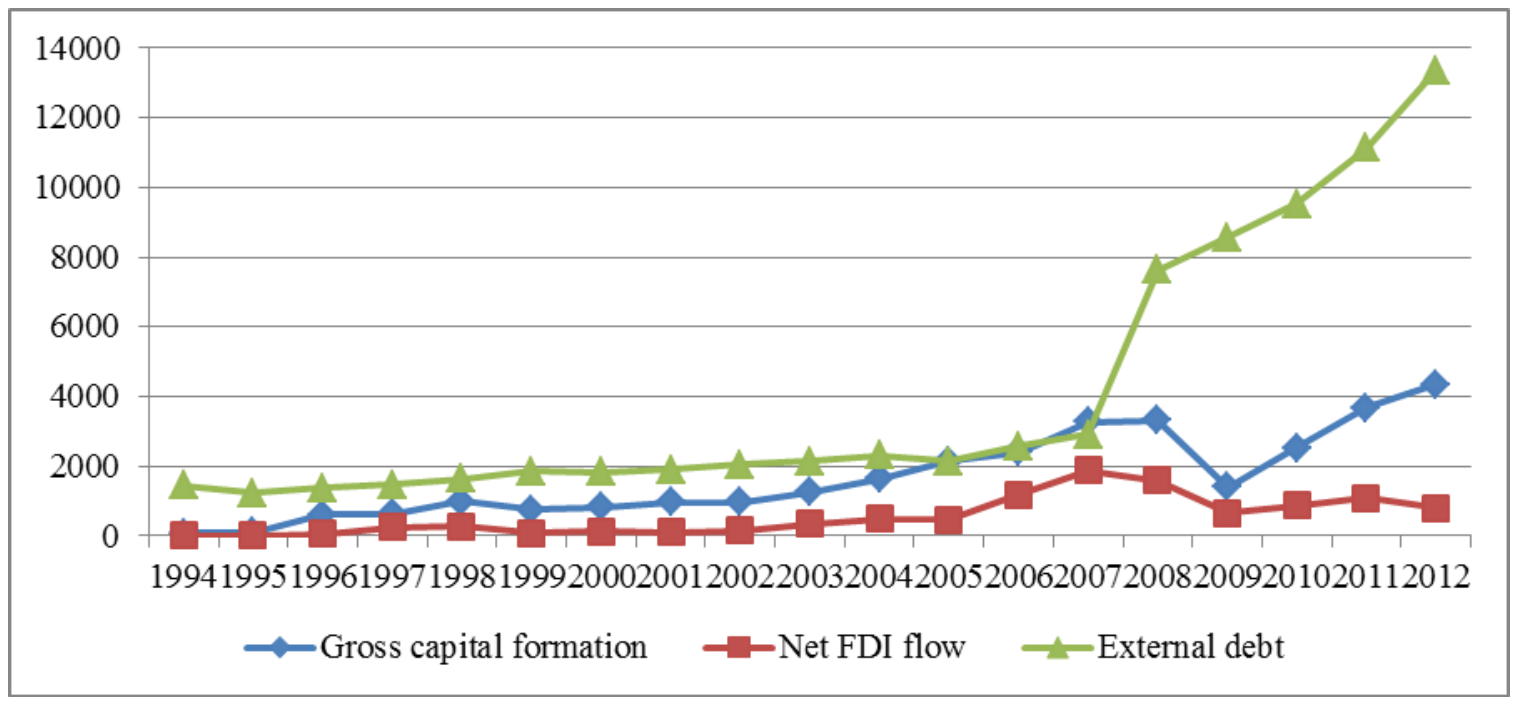

Figure 4.9 Trends in Armenian economy, millions USD

Figure 4.9 indicates the trends in Armenia's gross capital formation, external debt stocks and net FDI inflow. According to the graph, gross capital accumulation remains almost the same with ups and downs until 2003. After 2003 or the accession year to WTO, gross capital formation trend in Armenia performs a significant increase until 2008 and reaches to $\$ 4.8$ billion. However, it sharply falls to $\$ 3$ billion in 2009 because of the Crises and follows a slight increase in subsequent years. On the other hand, net FDI flow to Armenia has not increased substantially until 2003 as well. After 2003, it has had an increasing trend until 2008 and decreasing trend after 
2008. In general, the amount of net FDI flow to Armenia never reached to \$1billion during the whole period.

Indicated last trend in the graph, external debt stocks of Armenia, in total, have had an increasing trend throughout the period. Within 1994-2003, total external debt has raised from approximately $\$ 214$ million to $\$ 1994$ million or nearly $\$ 200$ million for each year. However, external debt stock reached to $\$ 7.4$ billion in 2011 or increased \$674 million for each year after 2003. Nevertheless, sharp increase in amount of external debt stock was observed after 2008 such as more than $\$ 1$ billion for each year. According to the CIA World Factbook, Armenia's total external debt stock at the end of 2012 is approximately $\$ 7.3$ billion.

After all, the impact of WTO accession on Armenia's economy should not also be appraised as positive. Although its GDP grew significantly after the accession, it also accompanied by the increasing of dependency from Russian support and support of financial institutions and Armenians from abroad. Anyway, total external debt of the country is seriously high which exceeds $60 \%$ of GDP. 


\section{Chapter 5}

\section{DATA AND METHODOLOGY}

During the past period after its creation, WTO has been subject to many studies. Various models has been used to estimate the impact of WTO over the international trade. Controversial and opposite results was found by many scholars. In this thesis, I attempt to estimate the possible impacts of WTO membership for Azerbaijan as a nonmember country through a case study and VAR models. Moreover, it is expected to evaluate the impacts of WTO membership for two member country (Georgia and Armenia) in this study as well. Thus, experience of these countries will be used to predict possible impacts for Azerbaijan economy in case of its accession to WTO.

Until now, WTO and Azerbaijan's accession process are studied in deep. In this thesis in addition to the coverage of the existing studies, I did political and economic analysis of Azerbaijan's macroeconomic performance for the transition period. Moreover, I studied Georgia and Armenia economies in a before-and-after WTO membership context. All these are aimed to create a general impression about WTO, Azerbaijan's accession and macroeconomic performance of Azerbaijan, Georgia and Armenia before applying an empirical model.

\subsection{Type and Source of Data}

In the research, the time-period is 1994-2012, 19 years. All data are yearly observations within this period and are measured in current USD as indicated in the World Bank database. With only some minor exceptions, data for Georgia, Armenia 
and Azerbaijan have been attained from the "World Development Indicators" database of the World Bank. However, the share of mining \& quarrying or oil-andgas production as percentage of Azerbaijan's GDP for 1994-2012 has been taken from the website of the Statistical Committee of Azerbaijan Republic. After doing mathematical calculation based on World Bank data, the result was subtracted from the normal GDP in order to find the non-resource data GDP for Azerbaijan. On the other hand, the data about the amount of Azerbaijan's oil export was taken from the www.economywatch.com and gas export was attained from the Statistical Committee of Azerbaijan Republic. After adding oil and gas export, the result was excluded from total export of Azerbaijan due to calculate non-resource export data for Azerbaijan.

\subsection{Methodology}

\subsubsection{Why Georgia and Armenia together with Azerbaijan?}

In this thesis, I will make analysis to find out the expected impacts of accession to the WTO for Azerbaijan economy. Azerbaijan is still out of this system and a case study will enable to carry out an empirical research of Azerbaijan's accession to WTO through studying economic process in Georgia and Armenia before and after their accession to the WTO. Thus, membership experience of Azerbaijan's neighbor countries (Georgia and Armenia) in the same regionwill shed light on the possible impacts of such an accession.

Georgia and Armenia are also situated in the South Caucasus region. In addition, all countries of this region had been a part of Soviet Union and centrally planned economic system until 1991. Moreover, all of them have faced with severe economic crises and hyperinflation in initial years of their independence. Also, all of them 
ended crises with the support of the International Monetary Fund (IMF) together with the World Bank thus showing similarities in economic policies during their transition period. In addition, from political point of view, all have unresolved regional conflicts which have serious impacts over their economies.

Nevertheless, there is an important difference among these countries that should be noted. Azerbaijan has an advantage of rich natural resources, especially huge oil and natural gas reserves which play crucial role in Azerbaijan's economy. Therefore, it would not be appropriate to include all these countries into an empirical analysis with natural resource biasedness of Azerbaijan. A solution to this problem is excluding the oil-and-gas contribution from the macroeconomic data used for the Azerbaijan's economy. This will happen simply through subtracting the amount of production in mining and quarrying industry from GDP and from total industrial production. This will produce a data for non-oil-gas economy in Azerbaijan and someone may correctly ask about the impact of oil-and-gas production over the production growth in other sectors.

This impact may be both positive (stimulating economy) or negative (resource curse) but without loss of generality I assume that there is not any net significant impact of oil-and-gas production over other sectors of the Azerbaijan's economy for the interest of this research. Although someone may also emphasize that oil and gas production has an impact over import of the country in terms of importing technologies and other kinds of capital goods which are used in this field, I will assume that this impact is not significant as well. 
For the analysis, a VAR (Vector Autoregression) model is applied first to estimate the impact of WTO membership over the economies of Georgia, Armenia as two separate regressions. Then, after subtracting the contribution of oil-and-gas production from Azerbaijan's GDP and total export, a panel data estimation is done with economic indicators of Georgia, Armenia and Azerbaijan to find out the impact of accession to the WTO within a panel. In the above mentioned VAR models, I used the data of eliminated-biasedness of oil-and-gas in Azerbaijan economy. Afterwards, to analyze the real prevailing situation, I used the original panel data, including oiland-gas contribution, and re-estimated the VAR model with the original data.

\subsubsection{Model Variables}

In this research, I use ordinary least squares method to estimate VAR models. With this respect, two VAR models are estimated for both Georgia and Armenia. First model is an ordinary VAR model and the second one uses first difference data. In addition, two other VAR models based on the panel data of the three countries are estimated with the above characteristics.

Accession to the WTO is directly related with international trade, export and import are model variables. In addition, WTO accession may increase the attractiveness for FDI flow to a new member. That is why I include net FDI flow in the model as another variable. Moreover, there is an interrelationship between international trade and net FDI flow with GDP and gross capital formation of the countries. In this sense, I define both GDP (non oil-and-gas GDP for Azerbaijan) and gross capital formation or gross domestic investments as variables of my model as well. On the other hand, international trade plays a crucial role in accumulating of external debt 
stocks of countries if import continuously exceeds export. Accordingly therefore, I also include the external debt/GDP ratio as variable into my model.

I include a binary variable "WTO membership" into the analysis which will get "zero" value in years of non-membership and "one" after the year of WTO membership as the most important variable in order to find out the impact of WTO accession over the economy of Georgia, Armenia and Azerbaijan (in case of acceding).

Overall, there are six variables that are regressed on each other within each VAR model. They are GDP, EXPORT, IMPORT, NET FDI FLOW, GROSS CAPITAL FORMATION, and EXTERNAL DEBT/GDP RATIO. The binary variable WTO MEMBERSHIP is used only as an explanatory variable in all regressions.

\subsubsection{Empirical Model}

The impact of WTO over the macroeconomic indicators of the member countries after their accession has not been studied sufficiently yet. Although there are numerous studies about the impact of WTO over the international trade, I could not find any empirical research which tests the relationship between GDP and WTO membership. The way of thinking in this paper is that WTO causes to the higher trade liberalization, especially for the countries accessed after 1995.On the other hand, WTO membership strengthens the competition in domestic economy and decreases the application of protection policy tools. Moreover, it is supposed that WTO membership makes countries more attractive for the FDIs. In this context, a VAR model may be build based on the assumptions that accession to the WTO affects directly export, import and net FDI flow and indirectly GDP and external debt stock/GDP ratio. 
Three different VAR models will be applied in this research: VAR model for Georgia, VAR model for Armenia and VAR model for panel data estimation. However, doing an empirical time series analysis requires stationarity of time series data or cointegration among variables of the model. For a VAR model, if the series are stationary of the same degree, cointegration must be tested among variables of the model. If cointegration exists, then the regression can be done. In this research, I will use Augmented Dickey-Fuller unit root test in order to define whether the series of variables are stationary or not.

Unfortunately, number of observations is not enough to test cointegration in my VAR models. That is why I will apply each VAR model in two different forms: first with non-stationary series if they are at the same degree of stationary, and second with the stationary series after making all series stationary through differencing. First forms will enable to find out the impact of WTO membership as a binary variable over the other variables of the VAR model with original statistics. Example, how much the GDP of Georgia differs after its accession to the WTO in comparison with non-membership years? However, this will not solve the question of cointegration. In this context, second form will address to solve the issue of cointegration through making all variables stationary. Although this will lead missing valuable interpretation the impact of WTO membership over the other variables, it will allow the statistically and economically significance as well as the sign of the coefficients front of the binary variable, WTO_membership.

\section{Individual VAR Model for Georgia}

a)

$$
X_{\mathrm{i}}=\alpha_{0 . \mathrm{i}}+\alpha_{1 . \mathrm{i}} \mathrm{X}_{1, \mathrm{t}-1}+\alpha_{2 . \mathrm{i}} \mathrm{X}_{2, \mathrm{t}-1}+\alpha_{3 . \mathrm{i}} \mathrm{X}_{3, \mathrm{t}-1}+\alpha_{4 . \mathrm{i}} \mathrm{X}_{4, \mathrm{t}-1}+\alpha_{5 . \mathrm{i}} \mathrm{X}_{5, \mathrm{t}-1}+\alpha_{6 . \mathrm{i}} \mathrm{X}_{6, \mathrm{t}-1}+\alpha_{7 . \mathrm{i}} \mathrm{X}_{7}+\varepsilon_{\mathrm{i}}
$$


b)

$$
\begin{aligned}
\mathrm{DX}_{\mathrm{i}}=\alpha_{8 . \mathrm{i}}+\alpha_{9 . \mathrm{i}} \mathrm{DX}_{1, \mathrm{t}-1}+\alpha_{10 . \mathrm{i}} \mathrm{DX}_{2, \mathrm{t}-1}+\alpha_{11 . \mathrm{i}} \mathrm{DX}_{3, \mathrm{t}-1}+\alpha_{12 . \mathrm{i}} \mathrm{DX}_{4, \mathrm{t}-1}+\alpha_{13 . \mathrm{i}} \mathrm{DX}_{5, \mathrm{t}-1} \\
+\alpha_{14 . \mathrm{i}} \mathrm{DX}_{6, \mathrm{t}-1}+\alpha_{15 . \mathrm{i}} \mathrm{X}_{7, \mathrm{t}-1}+\mathrm{u}_{\mathrm{i}}
\end{aligned}
$$

$\mathrm{X}_{\mathrm{i}} \in \mathrm{GEO}(\log (\mathrm{GDP})$, Export, Log(import), NetFDI, Debt_ratio, Gross_capital, WTO membership))

$\mathrm{X}_{1}: \log G D P_{G e o}$

$\mathrm{X}_{2}:$ Export $_{G e o}$

$\mathrm{X}_{3}: \log (\text { import })_{G e o}$

$\mathrm{X}_{4}: N e t F D I_{G e o}$

$\mathrm{X}_{5}:$ Debt_ratio $_{\text {Geo }}$

$\mathrm{X}_{6}:$ Gross_Capital $_{\text {Geo }}$

$\mathrm{X}_{7}:$ WTO_membership ${ }_{G e o}$

\section{Individual VAR Model for Armenia}

a)

$Y_{i}=\beta_{0 . i}+\beta_{1 . i} Y_{1, t-1}+Y_{2 . i} X_{2, t-1}+\beta_{3 . i} Y_{3, t-1}+\beta_{4 . i} Y_{4, t-1}+\beta_{5 . i} Y_{5, t-1}+\beta_{6 . i} Y_{6, t-1}+\beta_{7 . i} Y_{7}+\theta_{i}$

b)

$\mathrm{DY}_{\mathrm{i}}=\beta_{8 . \mathrm{i}}+\beta_{9 . \mathrm{i}} \mathrm{DY} Y_{1, \mathrm{t}-1}+\beta_{10 . \mathrm{i}} \mathrm{DY}_{2, \mathrm{t}-1}+\beta_{11 . \mathrm{i}} \mathrm{DY}_{3, \mathrm{t}-1}+\beta_{12 . \mathrm{i}} \mathrm{DY}_{4, \mathrm{t}-1}+\beta_{13 . \mathrm{i}} \mathrm{DY}_{5, \mathrm{t}-\mathrm{1}}+$

$$
+\beta_{14 . \mathrm{i}} \mathrm{DY}_{6, \mathrm{t}-1}+\beta_{15 . \mathrm{i}} \mathrm{Y}_{7, \mathrm{t}-1}+\theta_{\mathrm{i}}
$$

$\mathrm{Y}_{\mathrm{i}} \in \mathrm{ARM}$ (Log(GDP), Export, Import, NetFDI, D(Debt_ratio), Gross_capital, WTO_membership))

$\mathrm{Y}_{1}: \log G D P_{A r m}$

$\mathrm{Y}_{2}:$ Export $_{A r m}$

$\mathrm{Y}_{3}:$ Import $_{A r m}$

$\mathrm{Y}_{4}: N e t F D I_{A r m}$

$\mathrm{Y}_{5}: D\left(\right.$ Debt_ratio $\left._{\text {Arm }}\right)$ 
$\mathrm{Y}_{6}:$ Gross_Capital $_{\text {Arm }}$

$\mathrm{Y}_{7}:$ WTO_membership ${ }_{\text {Arm }}$

\section{Panel data estimation}

In the VAR model for panel data estimation, I will add additionally two binary (control) variables:

Sea_border: Equal 1 if a country has sea border and 0 if a country is land-locked. Obviously, this variable is 1 for both Azerbaijan and Georgia and 0 for Armenia along all period. It is used to control the impact of sea border advantage in terms of export (Export $*$ Sea_border) and import (Import $*$ Sea_border) opportunities.

Landborder_countries: Indicates the amount of neighboring countries from the land with open borders for economic transactions. Although Azerbaijan is bordered by five countries in land, value of this variable is always 4 for Azerbaijan, because, Azerbaijan-Armenia border has been always closed during the taken period in my research. In this context, its value s always two for Armenia as a result of closed borders with Azerbaijan and Turkey due to Nagorno-Karabakh conflict. On the other hand, its value for Georgia is four until Russia-Georgia war in August 2008, and three after that year as a result of closing Russia-Georgia borders.

\section{Panel VAR model: Azerbaijan without contribution of oil-and-gas}

a)

$Z_{\mathrm{i}}=\gamma_{0 . \mathrm{i}}+\gamma_{1 . \mathrm{i}} \mathrm{Z}+\gamma_{2 . \mathrm{i}} \mathrm{Z}_{2, \mathrm{t}-\mathrm{1}}+\gamma_{3 . \mathrm{i}} \mathrm{Z}_{3, \mathrm{t}-1}+\gamma_{4 . \mathrm{i}} \mathrm{Z}_{4, \mathrm{t}-1}+\gamma_{5 . \mathrm{i}} \mathrm{Z}_{5, \mathrm{t}-1}+\gamma_{6 . i} Z_{6, t-1}+\gamma_{7 . \mathrm{i}} Z_{7}+\gamma_{8 . \mathrm{i}} Z_{8}+\gamma_{9 . i} Z_{9}+\gamma$

b)

$\mathrm{DZ}_{\mathrm{i}}=\gamma_{8 . \mathrm{i}}+\gamma_{9 . \mathrm{i}} \mathrm{DZ}_{1, \mathrm{t}-1}+\gamma_{10 . \mathrm{i}} \mathrm{DZ}_{2, \mathrm{t}-1}+\gamma_{11 . \mathrm{i}} \mathrm{DZ} Z_{3, \mathrm{t}-1}+\gamma_{12 . \mathrm{i}} \mathrm{DZ} Z_{4, \mathrm{t}-1}+\gamma_{13 . \mathrm{i}} \mathrm{DZ}$

$$
+\gamma_{14 . \mathrm{i}} \mathrm{DZ}_{6, \mathrm{t}-1}+\gamma_{15 . \mathrm{i}} \mathrm{Z}_{7, \mathrm{t}-1}+\mathrm{u}_{\mathrm{i}}
$$


$\mathrm{Z}_{\mathrm{i}} \in$ Panel $\quad(\log (\mathrm{GDP}), \quad \mathrm{D}$ (Export), Import, Log(NetFDI), Debt_ratio, Gross_capital,Export*Sea_border, Import*Sea_border, Landborder_countries, WTO_membership)

$\mathrm{Z}_{1}: \log (\mathrm{GDP})$

$\mathrm{Z}_{2}: \mathrm{D}$ (Export)

$\mathrm{Z}_{3}:$ Import

$\mathrm{Z}_{4}: \log (\mathrm{NetFDI})$

$\mathrm{Z}_{5}$ : Debt_ratio

$\mathrm{Z}_{6}$ : Gross_capital

$\mathrm{Z}_{7}: \mathrm{D}($ Export $) *$ Sea_border

$\mathrm{Z}_{8}$ : Import*Sea_border

$\mathrm{Z}_{9}$ : Landborder_countries

$\mathrm{Z}_{10}$ :WTO_membership

\section{Panel VAR model: Azerbaijan with contribution of oil-and-gas}

This panel VAR model has almost the same equation structure with the previous one. The exceptions are:

$\mathrm{Z}_{1}: \log (\mathrm{GDP})$

$\mathrm{Z}_{2}$ : Export

$\mathrm{Z}_{7}$ : Export*Sea_border

\subsubsection{Testing for Stationarity: Unit Root Test}

Testing whether the data are stationary or non-stationary is crucial for the time series analysis. In this context, I have used Augmented Dickey-Fuller (ADF) unit root test. Because I do my research on the results of three different VAR models each model of which is based on different series of data, the unit root test must be implemented for each series, individually. For the panel series of data, existence of the unit root is 
tested through $A D F$ - Fisher Chi-square which assumes individual unit root process and Levin-Lin-Chu Test which assumes common unit root process. Here, we test the hypothesis whether the time series used is stationary or not. More precisely, the null hypothesis is:

$\mathrm{H}_{0}$ : The time series has a unit root

The important thing is the $t(=\operatorname{tau})$ statistic of the given time series data. Thus, if calculated absolute value of the $t$ statistics is greater than the absolute value of Dickey-Fuller or MacKinnon critical $\mathrm{t}$ values, then we fail to reject the null hypothesis which means that the time series is stationary (Gujarati, 1995, p.719). In opposite case, this means that the time series has unit root or it is non-stationary. Moreover, if the time series becomes stationary after first differencing, this implies that the time series which we test is "integrated of order 1 " or I(1) and in case of differencing twice, it becomes I(2). A stationary series without differencing is $\mathrm{I}(0)$.

\subsubsection{Testing for Granger Causality}

Existence of the causality between the variables of a model is essential in order to make an acceptable interpretation of that model's coefficients. In this research, Pairwise Granger Causality Test is used to find out if the WTO_membership Granger causes other variables of the models. The null hypothesis is:

$H_{0}$ : WTO_MEMBERSHIP does not Granger cause $\theta_{i}$,

Where $\theta_{i}$ refers to GDP, Export, Import, Net FDI flow, External Debt/GDP ratio, Gross Capital Formation in each separate VAR model. 


\subsubsection{Testing for Statistical Significance}

In this study, t-test is used for statistical significance of coefficients in all VAR models. Null hypothesis is:

Individual VAR models for Georgia:

$H_{0}: \alpha_{i}=0$

Individual VAR models for Armenia:

$H_{0}: \beta_{i}=0$

Panel VAR models:

$H_{0}: \gamma_{i}=0$ 


\section{Chapter 6}

\section{RESULTS AND INTERPRETATIONS}

\subsection{Unit Root Test Results}

Augmented Dickey-Fuller (ADF) test is used to test if the data series which are used in individual VAR models of Georgia and Armenia are stationary. Moreover, ADF Fisher Chi-square and Levin-Lin-Chu tests are used to test the existence of unit root in panel data series.

Table 6.1 indicates Augmented Dickey-Fuller unit root test results for the series in Georgia's VAR model. The identity of variables are stated in the first column of the table. The second and third columns indicates ADF test results.

Table 6.1 ADF results for Georgia's VAR model

\begin{tabular}{|l|c|l|}
\hline \multirow{2}{*}{ GDP } & \multicolumn{2}{|c|}{ ADF results } \\
\cline { 2 - 3 } & $\mathrm{I}(0)$ & \multicolumn{1}{|c|}{$\mathrm{I}(1)$} \\
\hline Export & 1.215633 & $-3.275029^{* *}$ \\
\hline Import & 2.711444 & $-2.599842^{*}$ \\
\hline External debt/GDP & 0.762089 & $-3.844063^{* * *}$ \\
\hline Net FDI Flow & -0.937487 & $-3.119403^{* *}$ \\
\hline Gross capital formation & -1.126298 & $-4.487458^{* * *}$ \\
\hline
\end{tabular}

Note: *, ** and *** denote significance level of 10 percent, 5 percent and 1 percent levels, respectively.

Source: Author's own creation

According to the table, all of time series in Georgia's VAR model are integrated of order one, I(1). GDP and external debt/GDP series of Georgia are I(1) at 5\% and 
$10 \%$ level of significance, respectively. Import, net FDI flow and gross capital formation series are $I(1)$ at even $1 \%$ level of significance. Only export is $I(1)$ at $10 \%$ significance level.

Table 6.2 represents ADF unit root test results for the series in VAR model for Armenia. Test results indicate that all of the series are I(1). More precisely, export and import time series are I(1) at 1\%, GDP, net FDI flow and gross capital formation time series are I(1) at 5\% and external debt/GDP ratio is statistically significant at $10 \%$ significance level.

Table 6.2 ADF results for Armenia's VAR model

\begin{tabular}{|l|l|l|}
\hline \multirow{2}{*}{} & \multicolumn{2}{l|}{ ADF results } \\
\cline { 2 - 3 } & $\mathrm{I}(0)$ & $\mathrm{I}(1)$ \\
\hline GDP & -0.318350 & $-3.636812^{* *}$ \\
\hline Import & 0.677793 & $-3.943350^{* * *}$ \\
\hline External debt/GDP & 0.238543 & $-4.069096^{* * *}$ \\
\hline Net FDI Flow & -2.656770 & $-2.719158^{*}$ \\
\hline Gross capital formation & -1.138930 & $-3.090175^{* *}$ \\
\hline Note: *,** and *** denote significance level of 10 percent, 5 percent and 1 percent levels, respectively.
\end{tabular}

Source: Author's own creation

Unit root test results for series of panel data are indicated in the following table. Both ADF Fisher Chi-square and Levin-Lin-Chu test are applied to the panel series with and without oil-and-gas contribution. As mentioned above, first test assumes individual unit root process where the second one assumes common unit root process.

ADF Fisher Chi-square test results indicate that all series are I(1) except the series of export without oil-and-gas contribution. The series of GDP with contribution of oil- 
and-gas is I(1) at 5\% level of significance. The series of GDP without oil-and-gas contribution and external debt/GDP ratio (with and without oil-and-gas) are I(1) at $10 \%$ level of significance. The series of export (without oil-and-gas), import, net FDI flow and gross capital formation are I(1) at $1 \%$ level of significance. Only the series of export without oil-and-gas contribution is I(1) at $10.91 \%$ level of significance. To remember, all these results are based on the assumption of individual unit root process.

Table 6.3. Unit root test results for panel data series

\begin{tabular}{|l|c|c|c|c|}
\hline \multirow{2}{*}{} & \multicolumn{2}{|c|}{ ADF Fisher } & \multicolumn{2}{c|}{ Levin-Lin- Chu t* } \\
\cline { 2 - 5 } & $\mathrm{I}(0)$ & $\mathrm{I}(1)$ & $\mathrm{I}(0)$ & $\mathrm{I}(1)$ \\
\hline GDP (with oil-and-gas) & 0.28622 & $14.0948^{* *}$ & 2.65611 & $-3.05615^{* * *}$ \\
\hline GDP (without oil-and-gas) & 0.28605 & $12.2228^{* *}$ & 2.94592 & $-2.33867^{* * *}$ \\
\hline Export (with oil-and-gas) & 0.06785 & $17.3655^{* * *}$ & 4.05510 & $-3.32179^{* * *}$ \\
\hline Export (without oil-and-gas) & 0.04334 & 10.3928 & 5.25022 & -1.02063 \\
\hline Import & 0.10423 & $20.1286^{* * *}$ & 3.24592 & $-3.86874^{* * *}$ \\
\hline $\begin{array}{l}\text { External debt/GDP (with oil-and- } \\
\text { gas) }\end{array}$ & 5.91102 & $11.5712^{*}$ & -0.23786 & $-2.14289^{* * *}$ \\
\hline $\begin{array}{l}\text { External debt/GDP (without oil- } \\
\text { and-gas) }\end{array}$ & 6.65055 & $11.9359^{*}$ & -0.63615 & $-2.29864^{* * *}$ \\
\hline Net FDI Flow & 3.92238 & $18.8584^{* * *}$ & -0.83698 & $-3.13961^{* * *}$ \\
\hline Gross capital formation & 0.70032 & $17.9833^{* * *}$ & 1.93931 & $-3.99097^{* * *}$ \\
\hline
\end{tabular}

Note: *,** and *** denote significance level of 10 percent, 5 percent and 1 percent levels, respectively.

Source: Author's own creation

Levin-Lin-Chu test with the assumption of common unit root process also finds all series I(1) except the series of export without contribution of oil-and-gas. According to the table 6.3, all series (with and without oil-and-gas) are $\mathrm{I}(1)$ at $1 \%$ level of significance. The only exception, export without oil-and-gas is I(1) at $15 \%$ level of significance which is considerable higher. 


\subsection{Pairwise Granger Causality Tests Results}

Pairwise Granger Causality Tests enable to find out the existence of interrelationship among the variables of a model. In this sense, here, Granger Causality between each pair of variables in both individual and panel VAR models could be tested. However, I will focus on existence of Granger Causality between the binary variable, WTO_membership and other variables which are used also as dependent variable. In all VAR models, WTO_membership is used as only explanatory variable. That is why test results below express only if WTO_membership does Granger Cause remaining variables.

The table below consists the Granger Causality test results. The first column indicates null hypotheses for each pair test. According to the test results, we can reject none of the null hypotheses for the pairs in Georgia's VAR model. This implies that we have not enough evidence to say that WTO_membership does Granger Cause the variables GDP, Export, Import, Debt_ratio, Gross_capital and NetFDI.

In case of pairs in Armenia's VAR model, test results indicate the existence of Granger Causality between WTO_membership -GDP and WTO_membership Gross_capital at 5\% level of significance, and WTO_membership - Import at $10 \%$ significance level. However, we fail to reject the null hypothesizes that "WTO membership does not Granger Cause" export, debt ratio and net FDI flow at even $10 \%$ of significance level. 
Table 6.4 Granger Causality test results

\begin{tabular}{|c|c|c|c|c|}
\hline \multirow[b]{2}{*}{ Null Hypothesis } & \multicolumn{4}{|c|}{$\begin{array}{l}\text { Pairwise Granger Causality Tests } \\
\text { F statistics }\end{array}$} \\
\hline & Georgia & Armenia & $\begin{array}{c}\text { Panel series } \\
\text { without oil- } \\
\text { and-gas }\end{array}$ & $\begin{array}{c}\text { Panel series } \\
\text { with oil- } \\
\text { and-gas }\end{array}$ \\
\hline $\begin{array}{l}\text { WTO_MEMBERSHIP does not Granger } \\
\text { Cause GDP }\end{array}$ & 0.83034 & $4.10760^{* *}$ & $4.10760^{* *}$ & 0.29243 \\
\hline $\begin{array}{l}\text { WTO_MEMBERSHIP does not Granger } \\
\text { Cause EXPORT }\end{array}$ & 0.27341 & 0.70564 & 0.70564 & 0.24785 \\
\hline $\begin{array}{l}\text { WTO_MEMBERSHIP does not Granger } \\
\text { Cause IMPORT }\end{array}$ & 0.72613 & $2.99573^{*}$ & $2.99573^{*}$ & 0.01797 \\
\hline $\begin{array}{l}\text { WTO_MEMBERSHIP does not Granger } \\
\text { Cause DEBT_RATIO }\end{array}$ & 0.06468 & 0.29904 & 0.29904 & 0.71192 \\
\hline $\begin{array}{l}\text { WTO_MEMBERSHIP does not Granger } \\
\text { Cause GROSS_CAPITAL }\end{array}$ & 0.63021 & $4.29495^{* *}$ & $4.29495^{* *}$ & 0.12197 \\
\hline $\begin{array}{l}\text { WTO_MEMBERSHIP does not Granger } \\
\text { Cause NETFDI }\end{array}$ & 1.36068 & 2.42370 & 2.42370 & 0.39382 \\
\hline
\end{tabular}

Source: Author's own creation

Application of Pairwise Granger Causality tests for the series in panel VAR models are represented in the third and fourth columns of the table 6.4. According to the table, in case of panel data series without oil-and-gas contribution, WTO_MEMBERSHIP does Granger Cause GDP and Gross_capital at 5\% and Import at $10 \%$ level of significance. Therefore, null hypotheses are rejected for these three pairs. However, not enough evidence is found to say that WTO_membership does Granger Cause Export, Debt_ratio and NetFDI. Consequently, it is failed to reject the hypotheses for those pairs. None of the F statistics values are statistically significant at $1 \%, 5 \%$ or $10 \%$ level. As a result, all hypotheses are failed to be rejected which implies no Granger Causality between WTO_membership and all panel data series with oil-and-gas contribution.

\subsection{Interpretation of VAR Model Results}

As mentioned in previous chapter, VAR model is applied to Georgia, Armenia and a panel dataset which include data series of Georgia, Armenia and Azerbaijan in order to estimate the impact of WTO membership on macroeconomic indicators of Georgia 
and Armenia individually, and to predict possible impacts of the membership for Azerbaijan economy in case of accession. Following tables show VAR model results. Tables with (a) code represent model results with original data series of I(1) without differencing. On the other hand, tables with (b) code indicate the model results with differentiated series of data which became $\mathrm{I}(0)$. In the tables, first row represents the dependent and first column independent variables. $*$, ** and $* * *$ implies statistical significance of the coefficients at $10 \%, 5 \%$ and $1 \%$, respectively. First row in all tables covers dependent variables and first columuns include independent variables.

\section{VAR Model Results for Georgia}

Table 6.5 (a) helps to interpret VAR model results for Georgia when all series are I(1). According to the model, there is positive and statistically significant impact of previous year's GDP growth and export and negative statistical significant impact of previous year's import growth, external debt/GDP ratio and gross capital formation over the economic growth rate of Georgia. Moreover, Georgia's export is statistically significantly affected by previous year's GDP growth and export level positively, and by import growth and external debt/GDP ratio negatively.

On the other hand, previous year's GDP growth and export level have statistically significant positive where external debt/GDP ratio has statistically significant negative impact over import growth rate of Georgia. Moreover, statistically significant negative impact of previous year's external debt/GDP ratio and gross capital formation on the net FDI flow to Georgia is found. External debt/GDP ratio has been affected positively by previous year's net FDI flow and its own value coefficients of which are both statistically significant. For gross capital formation, statistically significant positive impact of previous year's export and negative impact 
of previous year's import growth and external debt/GDP ratio is found. All other coefficients are statistically insignificant at $10 \%$ level.

Table 6.5 (a) VAR model results for Georgia

Vector Autoregression Estimates

Date: 15/12/13 Time: 01:22

Sample (adjusted): 19952012

Included observations: 18 after adjustments

Standard errors in ( )

\begin{tabular}{|c|c|c|c|c|c|c|}
\hline & LOG(GDP) & EXPORT & LOG(IMPORT) & NETFDI & DEBT_RATIO & $\begin{array}{c}\text { GROSS_CAPI } \\
\text { TAL }\end{array}$ \\
\hline LOG(GDP(-1)) & $\begin{array}{l}0.957772^{* * *} \\
(0.16290)\end{array}$ & $\begin{array}{l}1.44 \mathrm{E}+09^{* *} \\
(5.2 \mathrm{E}+08)\end{array}$ & $\begin{array}{l}1.036491^{\text {*** }} \\
(0.26848)\end{array}$ & $\begin{array}{l}7.32 \mathrm{E}+08 \\
(4.3 \mathrm{E}+08)\end{array}$ & $\begin{array}{l}0.078211 \\
(0.13517)\end{array}$ & $\begin{array}{l}1.32 \mathrm{E}+09 \\
(8.5 \mathrm{E}+08)\end{array}$ \\
\hline EXPORT(-1) & $\begin{array}{l}4.11 \mathrm{E}-10^{* * *} \\
(1.2 \mathrm{E}-10)\end{array}$ & $\begin{array}{l}1.729012^{* * *} \\
(0.38519)\end{array}$ & $\begin{array}{l}4.42 \mathrm{E}-10^{* *} \\
(2.0 \mathrm{E}-10)\end{array}$ & $\begin{array}{l}0.487851 \\
(0.31945)\end{array}$ & $\begin{array}{l}-8.70 \mathrm{E}-11 \\
(9.9 \mathrm{E}-11)\end{array}$ & $\begin{array}{l}1.855878^{* * *} \\
(0.62544)\end{array}$ \\
\hline LOG(IMPORT(-1)) & $\begin{array}{l}-0.383034^{* *} \\
(0.17891)\end{array}$ & $\begin{array}{l}-1.41 \mathrm{E}+09^{* *} \\
(5.8 \mathrm{E}+08)\end{array}$ & $\begin{array}{r}-0.227805 \\
(0.29487)\end{array}$ & $\begin{array}{l}-3.90 \mathrm{E}+08 \\
(4.8 \mathrm{E}+08)\end{array}$ & $\begin{array}{l}-0.061492 \\
(0.14846)\end{array}$ & $\begin{array}{l}-2.15 \mathrm{E}+09^{* *} \\
(9.3 \mathrm{E}+08)\end{array}$ \\
\hline NETFDI(-1) & $\begin{array}{l}6.23 \mathrm{E}-11 \\
(1.4 \mathrm{E}-10)\end{array}$ & $\begin{array}{l}-0.318568 \\
(0.45389)\end{array}$ & $\begin{array}{l}-1.31 \mathrm{E}-10 \\
(2.3 \mathrm{E}-10)\end{array}$ & $\begin{array}{r}0.233541 \\
(0.37643)\end{array}$ & $\begin{array}{l}2.26 \mathrm{E}-10^{*} \\
(1.2 \mathrm{E}-10)\end{array}$ & $\begin{array}{l}-0.241242 \\
(0.73699)\end{array}$ \\
\hline DEBT_RATIO(-1) & $\begin{array}{l}-1.258577^{* * *} \\
(0.30579)\end{array}$ & $\begin{array}{l}-1.87 \mathrm{E}+09^{*} \\
(9.8 \mathrm{E}+08)\end{array}$ & $\begin{array}{l}-1.764548^{* * *} \\
(0.50398)\end{array}$ & $\begin{array}{l}-3.01 \mathrm{E}+09^{* * *} \\
(8.2 \mathrm{E}+08)\end{array}$ & $\begin{array}{l}{ }^{* *} 1.288844^{* * *} \\
(0.25373)\end{array}$ & $\begin{array}{l}-4.89 \mathrm{E}+09^{* * *} \\
(1.6 \mathrm{E}+09)\end{array}$ \\
\hline $\begin{array}{l}\text { GROSS_CAPITAL } \\
(-1)\end{array}$ & $\begin{array}{l}-3.21 \mathrm{E}-10^{* * *} \\
(1.1 \mathrm{E}-10)\end{array}$ & $\begin{array}{l}-0.511067 \\
(0.34302)\end{array}$ & $\begin{array}{l}-3.02 \mathrm{E}-10 \\
(1.8 \mathrm{E}-10)\end{array}$ & $\begin{array}{l}-0.568348^{*} \\
(0.28448)\end{array}$ & $\begin{array}{l}7.97 \mathrm{E}-11 \\
(8.9 \mathrm{E}-11)\end{array}$ & $\begin{array}{l}-0.742778 \\
(0.55696)\end{array}$ \\
\hline $\mathrm{C}$ & $\begin{array}{l}9.455779^{*} \\
(4.59891)\end{array}$ & $\begin{array}{l}-1.11 \mathrm{E}+09 \\
(1.5 \mathrm{E}+10)\end{array}$ & $\begin{array}{l}3.729696 \\
(7.57970)\end{array}$ & $\begin{array}{l}-6.33 \mathrm{E}+09 \\
(1.2 \mathrm{E}+10)\end{array}$ & $\begin{array}{l}-0.530150 \\
(3.81605)\end{array}$ & $\begin{array}{l}1.84 \mathrm{E}+10 \\
(2.4 \mathrm{E}+10)\end{array}$ \\
\hline \multicolumn{7}{|l|}{ WTO_MEMBERSHI } \\
\hline $\mathrm{P}$ & $\begin{array}{l}0.334851^{* * *} \\
(0.07899)\end{array}$ & $\begin{array}{l}6.10 \mathrm{E}+08^{* *} \\
(2.5 \mathrm{E}+08)\end{array}$ & $\begin{array}{l}0.516446^{* * *} \\
(0.13018)\end{array}$ & $\begin{array}{l}6.01 \mathrm{E}+08^{* * *} \\
(2.1 \mathrm{E}+08)\end{array}$ & $\begin{array}{l}-0.151698^{* *} \\
(0.06554)\end{array}$ & $\begin{array}{l}1.03 \mathrm{E}+09^{* *} \\
(4.1 \mathrm{E}+08)\end{array}$ \\
\hline R-squared & 0.986333 & 0.981834 & 0.976514 & 0.870525 & 0.872214 & 0.899645 \\
\hline Adj. R-squared & 0.976766 & 0.969118 & 0.960074 & 0.779893 & 0.782764 & 0.829396 \\
\hline Sum sq. Resids & 0.094496 & $9.77 \mathrm{E}+17$ & 0.256688 & $6.72 \mathrm{E}+17$ & 0.065062 & $2.58 \mathrm{E}+18$ \\
\hline S.E. equation & 0.097209 & $3.13 \mathrm{E}+08$ & 0.160215 & $2.59 \mathrm{E}+08$ & 0.080661 & $5.08 \mathrm{E}+08$ \\
\hline F-statistic & 103.0977 & 77.21141 & 59.39897 & 9.605033 & 9.750841 & 12.80655 \\
\hline Log likelihood & 21.70524 & -372.3387 & 12.71149 & -368.9702 & 25.06412 & -381.0636 \\
\hline Akaike AIC & -1.522805 & 42.25985 & -0.523499 & 41.88558 & -1.896014 & 43.22928 \\
\hline Schwarz SC & -1.127084 & 42.65557 & -0.127778 & 42.28130 & -1.500293 & 43.62501 \\
\hline Mean dependent & 22.45950 & $2.14 \mathrm{E}+09$ & 21.69120 & $5.76 \mathrm{E}+08$ & 0.555211 & $1.76 \mathrm{E}+09$ \\
\hline S.D. dependent & 0.637740 & $1.78 \mathrm{E}+09$ & 0.801821 & $5.53 \mathrm{E}+08$ & 0.173061 & $1.23 \mathrm{E}+09$ \\
\hline
\end{tabular}

Determinant resid covariance (dof adj.)6.66E+41

Determinant resid covariance $1.96 \mathrm{E}+40$

Log likelihood $\quad-988.2183$

Akaike information criterion115.1354

Schwarz criterion 117.5097

Note: *, ** and *** denote significance level of 10 percent, 5 percent and 1 percent levels, respectively.

Source: Author's own creation 
According to the model results, WTO membership has had statistically significant positive impact on all variables except external debt/GDP ratio for which the impact is negative and also statistically significant. Georgia's GDP and import growth rate has been respectively, $33.48 \%$ and $51.64 \%$ higher after its membership to the WTO in comparison with before the membership on average. The amount of its export has increased $\$ 0.61$ billion with the impact of membership at WTO. The membership has positively impacted the net FDI flow to and Gross Capital Formation in Georgia in considerable amounts ( $\$ 0.601$ billion and $\$ 1.03$ billion). However, external debt/GDP ratio does not differ so much before and after the membership. Although the coefficient is statistically significant, the ratio has been just $0.151 \%$ lower after the membership in comparison with non-membership years.

The coefficients of WTO_membership in table 6.5 (a) create positive impression about accessing to WTO. However, here, the model assumes existence of cointegration without applying a cointegration test which is impossible because of insufficient number of observations. To avoid this problem, all series are made stationary through differentiating once and the table 6.5 (b) indicates the results of differenced once VAR model for Georgia.

As a result of differencing once, most of the statistically significant coefficients in table 6.5 (a) has become insignificant. Yearly change in GDP growth is negatively affected by yearly change in previous year's external debt/GDP ratio. Yearly export change is positively affected by its previous year's value and negatively impacted by yearly change in external debt/GDP ratio of the previous year. In addition, yearly change in external debt/GDP ratio of the previous year affects the yearly FDI flow negatively, and the yearly change in gross capital formation positively. 
Table 6.5 (b) VAR model results for Georgia

Vector Autoregression Estimates

Date: 15/12/13 Time:01:21

Sample (adjusted): 19962012

Included observations: 17 after adjustments

Standard errors in ( )

\begin{tabular}{|c|c|c|c|c|c|c|}
\hline & & & D(LOG(IN) & & & D(GROSS_CAPIT \\
\hline & $\mathrm{D}(\mathrm{LOG}(\mathrm{GDP}))$ & $\mathrm{D}(\mathrm{EXPORT})$ & ORT)) & $\mathrm{D}$ (NETFDI) & D(DEBT_RATIO) & $\mathrm{AL})$ \\
\hline$\overline{\overline{\mathrm{D}} \text { (LOG(GDP(- }}$ & & & & & & \\
\hline 1))) & $\begin{array}{l}-0.050562 \\
(0.32246)\end{array}$ & $\begin{array}{l}-1.23 \mathrm{E}+09 \\
(9.7 \mathrm{E}+08)\end{array}$ & $\begin{array}{l}-0.546091 \\
(0.55961)\end{array}$ & $\begin{array}{c}-1.44 \mathrm{E}+09 \\
(9.9 \mathrm{E}+08)\end{array}$ & $\begin{array}{l}0.423120 \\
(0.32435)\end{array}$ & $\begin{array}{l}-2.92 \mathrm{E}+09^{* *} \\
(1.3 \mathrm{E}+09)\end{array}$ \\
\hline D(EXPORT(-1)) & $\begin{array}{l}-6.20 \mathrm{E}-11 \\
(2.0 \mathrm{E}-10)\end{array}$ & $\begin{array}{l}1.500100^{* *} \\
(0.59008)\end{array}$ & $\begin{array}{l}-2.49 \mathrm{E}-10 \\
(3.4 \mathrm{E}-10)\end{array}$ & $\begin{array}{l}-0.060918 \\
(0.60021)\end{array}$ & $\begin{array}{l}2.33 \mathrm{E}-10 \\
(2.0 \mathrm{E}-10)\end{array}$ & $\begin{array}{l}1.965732^{* *} \\
(0.79402)\end{array}$ \\
\hline D(LOG(IMPOR & & & & & & \\
\hline $\mathrm{T}(-1)))$ & $\begin{array}{l}-0.055776 \\
(0.19139)\end{array}$ & $\begin{array}{l}-7.19 \mathrm{E}+08 \\
(5.8 \mathrm{E}+08)\end{array}$ & $\begin{array}{l}0.274329 \\
(0.33214)\end{array}$ & $\begin{array}{l}2.97 \mathrm{E}+08 \\
(5.9 \mathrm{E}+08)\end{array}$ & $\begin{array}{l}-0.203575 \\
(0.19251)\end{array}$ & $\begin{array}{l}-1.20 \mathrm{E}+09 \\
(7.8 \mathrm{E}+08)\end{array}$ \\
\hline D(NETFDI(-1)) & $\begin{array}{l}1.78 \mathrm{E}-10 \\
(1.4 \mathrm{E}-10)\end{array}$ & $\begin{array}{l}0.260054 \\
(0.42978)\end{array}$ & $\begin{array}{l}1.01 \mathrm{E}-11 \\
(2.5 \mathrm{E}-10)\end{array}$ & $\begin{array}{l}0.235333 \\
(0.43716)\end{array}$ & $\begin{array}{l}1.15 \mathrm{E}-10 \\
(1.4 \mathrm{E}-10)\end{array}$ & $\begin{array}{l}0.854846 \\
(0.57832)\end{array}$ \\
\hline D(DEBT_RATI & & & & & & \\
\hline $\mathrm{O}(-1))$ & $\begin{array}{l}-0.652375^{*} \\
(0.33488)\end{array}$ & $\begin{array}{l}-2.16 \mathrm{E}+09^{* *} \\
(1.0 \mathrm{E}+09)\end{array}$ & $\begin{array}{l}-0.975869 \\
(0.58116)\end{array}$ & $\begin{array}{l}-2.47 \mathrm{E}+09^{* *} \\
(1.0 \mathrm{E}+09)\end{array}$ & $\begin{array}{l}0.538103 \\
(0.33685)\end{array}$ & $\begin{array}{l}5.63 \mathrm{E}+09^{* * *} \\
(1.4 \mathrm{E}+09)\end{array}$ \\
\hline D(GROSS_CAP) & & & & & & \\
\hline TAL $(-1))$ & $\begin{array}{l}-3.93 \mathrm{E}-11 \\
(1.2 \mathrm{E}-10)\end{array}$ & $\begin{array}{l}-0.587311 \\
(0.35517)\end{array}$ & $\begin{array}{l}1.07 \mathrm{E}-10 \\
(2.0 \mathrm{E}-10)\end{array}$ & $\begin{array}{l}-0.200316 \\
(0.36126)\end{array}$ & $\begin{array}{l}-1.03 \mathrm{E}-10 \\
(1.2 \mathrm{E}-10)\end{array}$ & $\begin{array}{l}-1.186123^{* *} \\
(0.47791)\end{array}$ \\
\hline $\mathrm{C}$ & -0.031125 & $3.19 \mathrm{E}+08$ & -0.026043 & $1.46 \mathrm{E}+08$ & 0.057551 & $6.77 \mathrm{E}+08^{* *}$ \\
\hline WTO_MEMBE & & & & & & \\
\hline RSHIP & $0.212436^{*}$ & -26687919 & 0.302585 & $1.30 \mathrm{E}+08$ & -0.142720 & $2.98 \mathrm{E}+08$ \\
\hline & $(0.10146)$ & $(3.1 \mathrm{E}+08)$ & $(0.17608)$ & $(3.1 \mathrm{E}+08)$ & $(0.10206)$ & $(4.1 \mathrm{E}+08)$ \\
\hline R-squared & 0.633132 & 0.643038 & 0.493392 & 0.509265 & 0.434466 & 0.739299 \\
\hline Adj. R-squared & 0.347791 & 0.365401 & 0.099363 & 0.127582 & -0.005393 & 0.536532 \\
\hline Sum sq. resids & 0.117666 & $1.07 \mathrm{E}+18$ & 0.354369 & $1.11 \mathrm{E}+18$ & 0.119050 & $1.94 \mathrm{E}+18$ \\
\hline S.E. equation & 0.114341 & $3.45 \mathrm{E}+08$ & 0.198430 & $3.51 \mathrm{E}+08$ & 0.115012 & $4.64 \mathrm{E}+08$ \\
\hline F-statistic & 2.218860 & 2.316111 & 1.252172 & 1.334263 & 0.987739 & 3.646052 \\
\hline Log likelihood & 18.14958 & -352.9109 & 8.778396 & -353.2002 & 18.05014 & -357.9572 \\
\hline Akaike AIC & -1.194069 & 42.46011 & -0.091576 & 42.49414 & -1.182370 & 43.05379 \\
\hline Schwarz SC & -0.801968 & 42.85221 & 0.300524 & 42.88624 & -0.790269 & 43.44589 \\
\hline Mean dependent & 0.104173 & $3.28 \mathrm{E}+08$ & 0.123040 & 46018395 & 0.022561 & $2.49 \mathrm{E}+08$ \\
\hline S.D. dependent & 0.141583 & $4.33 \mathrm{E}+08$ & 0.209089 & $3.76 \mathrm{E}+08$ & 0.114703 & $6.82 \mathrm{E}+08$ \\
\hline$\overline{\text { Determinant resi }}$ & id covariance & of adj.)3.96E+c & $\overline{+42}$ & & & \\
\hline Determinant resi & id covariance & $8.73 \mathrm{E}+$ & +40 & & & \\
\hline Log likelihood & & -946.02 & 240 & & & \\
\hline Akaike informati & ion criterion & 116.944 & 440 & & & \\
\hline Schwarz criterior & & 119.296 & 966 & & & \\
\hline
\end{tabular}

Differencing once all I(1) series enable to find true effect of the binary variable WTO_membership. According to the results, WTO membership affects only the yearly change in GDP growth rate statistically significantly and its sign is positive. It has been $21.2 \%$ more after the accession as compared to pre-accession period. On the 
other hand, the impact of WTO membership is negative for yearly change in export which implies decreasing effect however, the coefficient is not statistically significant. None of the remaining coefficients are statistically significant as well.

\section{VAR Model Results for Armenia}

Results of the VAR model for Armenia with I(1) series does not ensure many statistically significant coefficients. Armenia's economic growth rate is affected positively by its own value and negatively import of the previous year. Moreover, previous year's GDP growth rate and yearly change in external debt/GDP ratio affects Armenia's export positively but, effect of gross capital formation is negative. Yearly change in external debt/GDP ratio affects the Armenia's import positively as well. Net FDI flow to Armenia is affected negatively by the previous year's import and positively by the previous year's gross capital formation. Moreover, the gross capital formation in Armenia is affected by the previous year's export positively and import negatively.

According to the table 6.6 (a), no evidence is found to claim that WTO membership has significant impacts over any of the variables. Interestingly, model results indicate that WTO membership has had negative impact on GDP growth rate, import, net FDI flow, Gross Capital Formation and first difference of external debt/GDP ratio. Positive impact was only found on export. However, none of the coefficients at WTO_membership are statistically significant. Nevertheless, another VAR model is done for Armenia because of the same issue, states in previous part for Georgia. 
Table 6.6 (a) VAR model results for Armenia

Vector Autoregression Estimates

Date: 15/12/13 Time: 07:30

Sample (adjusted): 19962012

Included observations: 17 after adjustments

Standard errors in ()

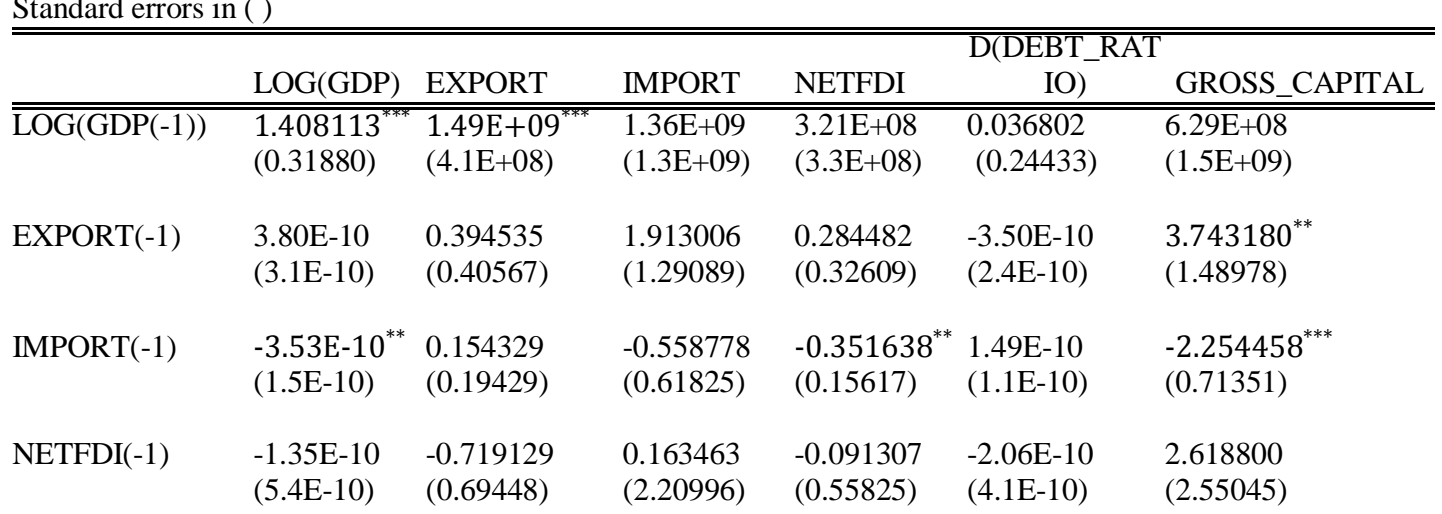

\section{D(DEBT_RATIO(}

$\begin{array}{lllllll}0.370531 & 8.77 \mathrm{E}+08^{*} & 3.04 \mathrm{E}+09^{* *} & 2.39 \mathrm{E}+08 & -0.204648 & 2.95 \mathrm{E}+09 \\ & (0.33939) & (4.4 \mathrm{E}+08) & (1.4 \mathrm{E}+09) & (3.5 \mathrm{E}+08) & (0.26011) & (1.6 \mathrm{E}+09)\end{array}$

GROSS_CAPITA

$\begin{array}{lllllll}\mathrm{L}(-1) & -1.82 \mathrm{E}-11 & -0.514551^{* * *} & 0.137773 & 0.294879^{* *} & 6.49 \mathrm{E}-11 & 0.932720 \\ & (1.1 \mathrm{E}-10) & (0.14167) & (0.45083) & (0.11388) & (8.4 \mathrm{E}-11) & (0.52029) \\ \mathrm{C} & & & & & & \\ & -8.447212 & -3.13 \mathrm{E}+10 & -2.86 \mathrm{E}+10 & -6.64 \mathrm{E}+09 & -0.708048 & -1.31 \mathrm{E}+10 \\ & (6.70521) & (8.7 \mathrm{E}+09) & (2.8 \mathrm{E}+10) & (7.0 \mathrm{E}+09) & (5.13889) & (3.2 \mathrm{E}+10)\end{array}$

WTO MEMBERS

\begin{tabular}{lllllll} 
HIP & -0.000847 & 2814679 & $-3.45 \mathrm{E}+08$ & $-1.02 \mathrm{E}+08$ & -0.100289 & $-6.49 \mathrm{E}+08$ \\
& $(0.10234)$ & $(1.3 \mathrm{E}+08)$ & $(4.2 \mathrm{E}+08)$ & $(1.1 \mathrm{E}+08)$ & $(0.07844)$ & $(4.9 \mathrm{E}+08)$ \\
\hline \hline R-squared & 0.992403 & 0.986181 & 0.970224 & 0.943973 & 0.770133 & 0.955438 \\
Adj. R-squared & 0.986493 & 0.975432 & 0.947065 & 0.900396 & 0.591347 & 0.920779 \\
Sum sq. resids & 0.070162 & $1.18 \mathrm{E}+17$ & $1.20 \mathrm{E}+18$ & $7.64 \mathrm{E}+16$ & 0.041211 & $1.59 \mathrm{E}+18$ \\
S.E. equation & 0.088294 & $1.15 \mathrm{E}+08$ & $3.65 \mathrm{E}+08$ & 92112457 & 0.067669 & $4.21 \mathrm{E}+08$ \\
F-statistic & 167.9436 & 91.75152 & 41.89395 & 21.66228 & 4.307575 & 27.56650 \\
Log likelihood & 22.54442 & -334.1832 & -353.8617 & -330.4709 & 27.06722 & -356.2977 \\
Akaike AIC & -1.711108 & 40.25685 & 42.57196 & 39.82011 & -2.243203 & 42.85855 \\
Schwarz SC & -1.319008 & 40.64895 & 42.96406 & 40.21221 & -1.851103 & 43.25065 \\
Mean dependent & 22.12896 & $1.16 \mathrm{E}+09$ & $2.38 \mathrm{E}+09$ & $3.47 \mathrm{E}+08$ & 0.028433 & $1.70 \mathrm{E}+09$ \\
S.D. dependent & 0.759725 & $7.31 \mathrm{E}+08$ & $1.58 \mathrm{E}+09$ & $2.92 \mathrm{E}+08$ & 0.105855 & $1.50 \mathrm{E}+09$ \\
\hline \hline
\end{tabular}

Determinant resid covariance (dof adj.) $7.42 \mathrm{E}+58$

Determinant resid covariance $\quad 1.63 \mathrm{E}+57$

Log likelihood $\quad-1264.508$

Akaike information criterion $\quad 154.4128$

Schwarz criterion 156.7654

Note: $* * *$ and $* * *$ denote significance level of 10 percent, 5 percent and 1 percent levels, respectively.

Source: Author's own creation

Table 6.6 (b) indicates VAR model results for Armenia with once differentiated series of data. According to these results, the impact of yearly change in previous year's import over yearly change in GDP growth rate is negative and statistically significant while remaining coefficients are insignificant. Yearly export change is 
positively affected by previous year's value of its own and import which the last does not make sense economically.

Statistically significant impact of $W T O_{-}$membership is found only over the yearly change in export and import. Both coefficients are positive but, import change is 2.15 times more $(5.68 / 2.63)$ than the change in export as a result of the membership. This remembers the trends in Armenia's export and import volumes before and after their accession to WTO in chapter 4.

Table 6.6 (b) VAR model results for Armenia Vector Autoregression Estimates Date: 16/12/13 Time: 01:30 Sample (adjusted): 19962012 Included observations: 17 after adjustments Standard errors in ( )

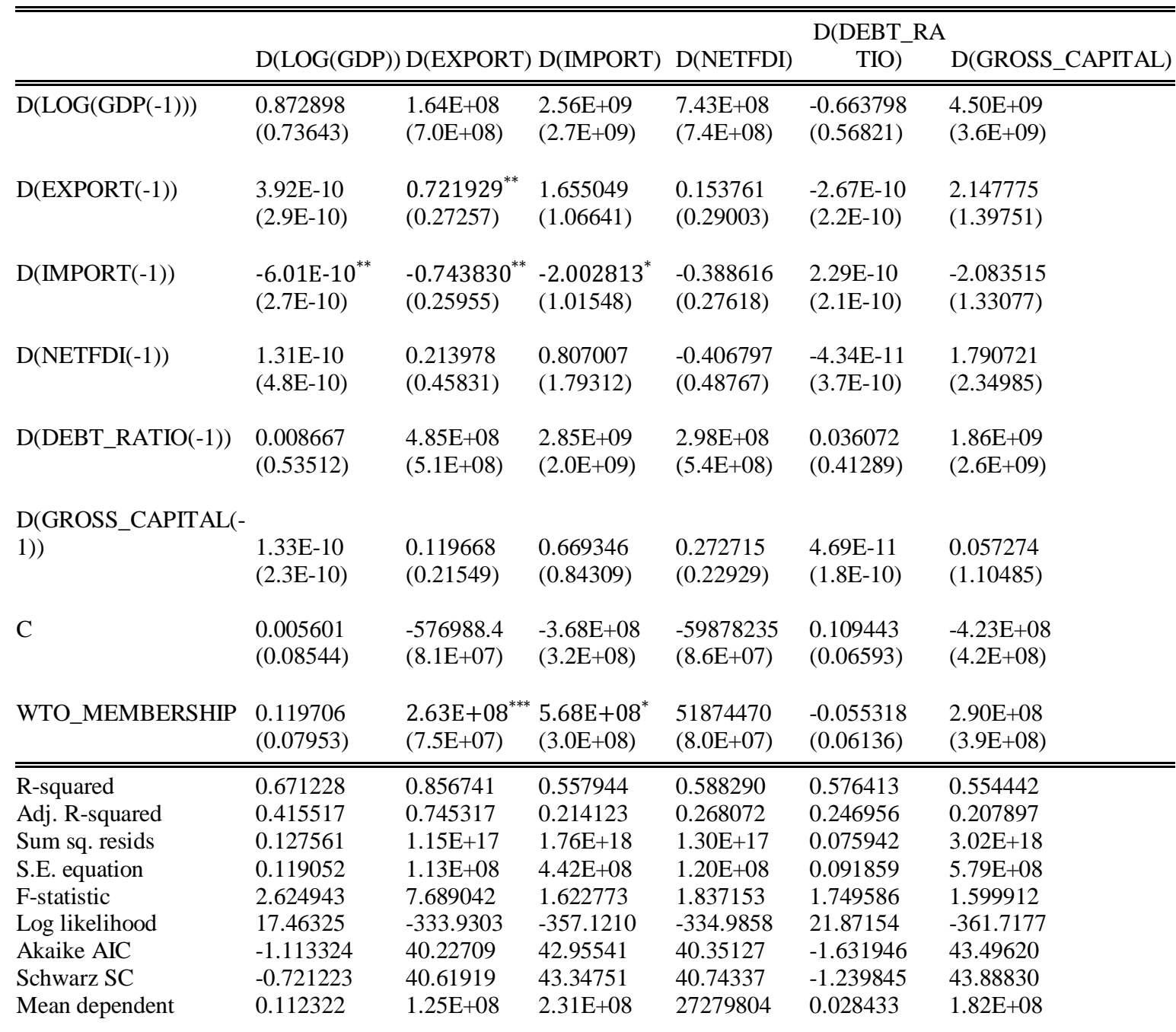


Determinant resid covariance (dof adj.) 9.73E+59

Determinant resid covariance

$2.14 \mathrm{E}+58$

Log likelihood

$-1286.381$

Akaike information criterion

156.9860

Schwarz criterion

159.3386

Note: *, ** and *** denote significance level of 10 percent, 5 percent and 1 percent levels, respectively.

Source: Author's own creation

\section{Panel VAR Model Results}

As mentioned above, panel VAR model is applied to the panel data with and without oil-and-gas contribution in Azerbaijan economy of which each has done with I(1) series at first and $\mathrm{I}(0)$ after differencing once. Thus, there is a considerable oil-andgas contribution in Azerbaijan's GDP and export, and external debt/GDP ratio as a result of the division.

\section{Without Contribution of Oil-and-Gas}

Table 6.7 (a) consists of VAR model results based on the panel data which oil-andgas contribution has been excluded from the series on Azerbaijan. Interpreting in short, previous year's GDP growth affects its own value, gross capital formation and imports positively. Previous year's external debt/GDP ratio has statistically significant impact on only its own value. Gross capital formation in previous year affects GDP growth, its own value and the import positively but, the impact is negative on the external debt/GDP ratio. However, it is found that import has negative significant impact over GDP growth rate and gross capital formation. Impact of the growth in net FDI flow is only statistically significant over its own value. Interaction variables $(\mathrm{D}(\mathrm{EXPORT}) *$ SEA_BORDER, IMPORT*SEA_ BORDER) and another binary variable (LANDBORDER_ COUNTRIES) in the model shows that having sea borders affects the impact of yearly export change over GDP growth negatively. Moreover, that affects significantly and positively the impact of import over GDP growth, gross capital and the growth in net FDI flow. 
Interestingly, model results indicate significantly negative impact of opening land borders with a country over GDP growth, gross capital and import.

Table 6.7 (a) Panel VAR model results without contrubition of oil-and-gas Vector Autoregression Estimates

Date: 18/12/13 Time: 03:22

Sample (adjusted): 19962012

Included observations: 51 after adjustments

Standard errors in ( )

\begin{tabular}{|c|c|c|c|c|c|c|}
\hline & LOG(GDP) & $\mathrm{D}(\mathrm{EXPORT})$ & DEBT_RATIO & $\begin{array}{l}\text { GROSS_CAP } \\
\text { ITAL }\end{array}$ & IMPORT & LOG(NETFDI) \\
\hline LOG(GDP(-1)) & $\begin{array}{l}1.014864^{* * *} \\
(0.10356)\end{array}$ & $\begin{array}{l}31920057 \\
(1.2 \mathrm{E}+08)\end{array}$ & $\begin{array}{l}0.043592 \\
(0.07854)\end{array}$ & $\begin{array}{l}1.01 \mathrm{E}+09^{* *} \\
(4.9 \mathrm{E}+08)\end{array}$ & $\begin{array}{l}1.36 \mathrm{E}+09^{* * *} \\
(3.9 \mathrm{E}+08)\end{array}$ & $\begin{array}{l}0.715471 \\
(0.51548)\end{array}$ \\
\hline D(EXPORT(-1)) & $\begin{array}{l}5.40 \mathrm{E}-11 \\
(5.8 \mathrm{E}-11)\end{array}$ & $\begin{array}{l}0.015811 \\
(0.06595)\end{array}$ & $\begin{array}{r}-3.39 \mathrm{E}-11 \\
(4.4 \mathrm{E}-11)\end{array}$ & $\begin{array}{l}0.356713 \\
(0.27396)\end{array}$ & $\begin{array}{l}0.276294 \\
(0.22036)\end{array}$ & $\begin{array}{l}1.12 \mathrm{E}-10 \\
(2.9 \mathrm{E}-10)\end{array}$ \\
\hline DEBT_RATIO(-1) & $\begin{array}{r}-0.099590 \\
(0.14202)\end{array}$ & $\begin{array}{l}2.75 \mathrm{E}+08 \\
(1.6 \mathrm{E}+08)\end{array}$ & $\begin{array}{l}0.813785^{* * *} \\
(0.10770)\end{array}$ & $\begin{array}{l}4.08 \mathrm{E}+08 \\
(6.7 \mathrm{E}+08)\end{array}$ & $\begin{array}{l}3581147 . \\
(5.4 \mathrm{E}+08)\end{array}$ & $\begin{array}{r}-0.582390 \\
(0.70692)\end{array}$ \\
\hline $\begin{array}{l}\text { GROSS_CAPITAL } \\
(-1)\end{array}$ & $\begin{array}{l}7.59 \mathrm{E}-11^{* *} \\
(3.2 \mathrm{E}-11)\end{array}$ & $\begin{array}{l}0.026073 \\
(0.03579)\end{array}$ & $\begin{array}{l}-5.97 \mathrm{E}-11^{* *} \\
(2.4 \mathrm{E}-11)\end{array}$ & $\begin{array}{l}1.254326^{* * *} \\
(0.14865)\end{array}$ & $\begin{array}{l}0.369497^{* * *} \\
(0.11957)\end{array}$ & $\begin{array}{l}1.74 \mathrm{E}-10 \\
(1.6 \mathrm{E}-10)\end{array}$ \\
\hline IMPORT(-1) & $\begin{array}{l}-1.53 \mathrm{E}-10^{* * *} \\
(5.3 \mathrm{E}-11)\end{array}$ & $\begin{array}{r}-0.035359 \\
(0.06043)\end{array}$ & $\begin{array}{l}6.28 \mathrm{E}-11 \\
(4.0 \mathrm{E}-11)\end{array}$ & $\begin{array}{l}-0.848249^{* * *} \\
(0.25102)\end{array}$ & $\begin{array}{r}-0.188637 \\
(0.20191)\end{array}$ & $\begin{array}{r}-4.30 \mathrm{E}-10 \\
(2.7 \mathrm{E}-10)\end{array}$ \\
\hline LOG(NETFDI(-1)) & $\begin{array}{r}-0.001538 \\
(0.02168)\end{array}$ & $\begin{array}{l}21139001 \\
(2.5 \mathrm{E}+07)\end{array}$ & $\begin{array}{l}0.007128 \\
(0.01644)\end{array}$ & $\begin{array}{l}33462917 \\
(1.0 \mathrm{E}+08)\end{array}$ & $\begin{array}{l}1.04 \mathrm{E}+08 \\
(8.2 \mathrm{E}+07)\end{array}$ & $\begin{array}{l}0.565341^{* * *} \\
(0.10789)\end{array}$ \\
\hline $\mathrm{C}$ & $\begin{array}{l}0.207170 \\
(2.03518)\end{array}$ & $\begin{array}{r}-9.73 E+08 \\
(2.3 E+09)\end{array}$ & $\begin{array}{r}-0.986724 \\
(1.54343)\end{array}$ & $\begin{array}{r}-2.04 \mathrm{E}+10 \\
(9.6 \mathrm{E}+09)\end{array}$ & $\begin{array}{c}-2.83 \mathrm{E}+10^{* * *} \\
(7.7 \mathrm{E}+09)\end{array}$ & $\begin{array}{r}-6.176550 \\
(10.1304)\end{array}$ \\
\hline $\begin{array}{l}\text { D(EXPORT)*SEA } \\
\text { BORDER }\end{array}$ & $\begin{array}{c}-1.58 \mathrm{E}-10^{* *} \\
(6.4 \mathrm{E}-11)\end{array}$ & $\begin{array}{l}0.992550^{* * *} \\
(0.07260)\end{array}$ & $\begin{array}{l}2.57 \mathrm{E}-11 \\
(4.9 \mathrm{E}-11)\end{array}$ & $\begin{array}{r}-0.003770 \\
(0.30160)\end{array}$ & $\begin{array}{l}0.454134^{*} \\
(0.24259)\end{array}$ & $\begin{array}{r}-3.15 \mathrm{E}-10 \\
(3.2 \mathrm{E}-10)\end{array}$ \\
\hline $\begin{array}{l}\text { IMPORT*SEA_BO } \\
\text { RDER }\end{array}$ & $\begin{array}{l}1.06 \mathrm{E}-10^{* * *} \\
(2.6 \mathrm{E}-11)\end{array}$ & $\begin{array}{l}0.001303 \\
(0.02969)\end{array}$ & $\begin{array}{r}-2.73 \mathrm{E}-11 \\
(2.0 \mathrm{E}-11)\end{array}$ & $\begin{array}{l}0.416251^{* * *} \\
(0.12333)\end{array}$ & $\begin{array}{l}0.553364^{* * *} \\
(0.09920)\end{array}$ & $\begin{array}{l}2.48 \mathrm{E}-10^{*} \\
(1.3 \mathrm{E}-10)\end{array}$ \\
\hline $\begin{array}{l}\text { LANDBORDER_C } \\
\text { OUNTRIES }\end{array}$ & $\begin{array}{l}-0.110184^{* * *} \\
(0.03668)\end{array}$ & $\begin{array}{r}-50995967 \\
(4.2 \mathrm{E}+07)\end{array}$ & $\begin{array}{l}0.000540 \\
(0.02782)\end{array}$ & $\begin{array}{l}-4.76 \mathrm{E}+08^{* * *} \\
(1.7 \mathrm{E}+08)\end{array}$ & $\begin{array}{c}-6.62 \mathrm{E}+08^{* * *} \\
(1.4 \mathrm{E}+08)\end{array}$ & $\begin{array}{r}-0.121412 \\
(0.18260)\end{array}$ \\
\hline $\begin{array}{l}\text { WTO_MEMBERS } \\
\text { HIP }\end{array}$ & $\begin{array}{l}0.133980^{* *} \\
(0.06147)\end{array}$ & $\begin{array}{r}-29344525 \\
(7.0 \mathrm{E}+07)\end{array}$ & $\begin{array}{r}-0.046559 \\
(0.04662)\end{array}$ & $\begin{array}{r}-3.50 \mathrm{E}+08 \\
(2.9 \mathrm{E}+08)\end{array}$ & $\begin{array}{r}-1.46 \mathrm{E}+08 \\
(2.3 \mathrm{E}+08)\end{array}$ & $\begin{array}{l}0.068605 \\
(0.30600)\end{array}$ \\
\hline $\begin{array}{l}\text { R-squared } \\
\text { Adj. R-squared } \\
\text { Sum sq. resids } \\
\text { S.E. equation } \\
\text { F-statistic } \\
\text { Log likelihood } \\
\text { Akaike AIC } \\
\text { Schwarz SC } \\
\text { Mean dependent } \\
\text { S.D. dependent }\end{array}$ & $\begin{array}{c}0.983080 \\
0.978850 \\
0.571120 \\
0.119491 \\
232.4105 \\
42.17964 \\
-1.222731 \\
-0.806063 \\
22.50273 \\
0.821641\end{array}$ & $\begin{array}{c}0.970769 \\
0.963461 \\
7.35 \mathrm{E}+17 \\
1.36 \mathrm{E}+08 \\
132.8415 \\
-1021.156 \\
40.47671 \\
40.89338 \\
3.42 \mathrm{E}+08 \\
7.09 \mathrm{E}+08\end{array}$ & $\begin{array}{c}0.826730 \\
0.783413 \\
0.328470 \\
0.090619 \\
19.08541 \\
56.28508 \\
-1.775886 \\
-1.359217 \\
0.453312 \\
0.194716\end{array}$ & $\begin{array}{c}0.970418 \\
0.963022 \\
1.27 \mathrm{E}+19 \\
5.63 \mathrm{E}+08 \\
131.2155 \\
-1093.785 \\
43.32489 \\
43.74156 \\
2.90 \mathrm{E}+09 \\
2.93 \mathrm{E}+09\end{array}$ & $\begin{array}{c}0.988938 \\
0.986173 \\
8.21 \mathrm{E}+18 \\
4.53 \mathrm{E}+08 \\
357.6094 \\
-1082.681 \\
42.88947 \\
43.30614 \\
4.30 \mathrm{E}+09 \\
3.85 \mathrm{E}+09\end{array}$ & $\begin{array}{r}0.857110 \\
0.821388 \\
14.15065 \\
0.594782 \\
23.99360 \\
-39.67320 \\
1.987184 \\
2.403853 \\
20.08553 \\
1.407351\end{array}$ \\
\hline
\end{tabular}

Determinant resid covariance (dof adj.)1.57E+45 
Determinant resid covariance $\quad 3.67 \mathrm{E}+44$

Log likelihood $\quad-3050.818$

Akaike information criterion $\quad 122.2281$

$\begin{array}{ll}\text { Schwarz criterion } & 124.7282\end{array}$

Note: $*, * *$ and $* * *$ denote significance level of 10 percent, 5 percent and 1 percent levels, respectively.

Source: Author's own creation

However, the focus in the table is toward the coefficients of WTO_MEMBERSHIP which have statistically siginificant impact on only the GDP growth rate. It implies that the GDP growth in countries within the panel has been $13.39 \%$ higher after their membership in comparison with non-membership year's growth. This impact over remaining variables is statistically insignficant and negative for yearly export change, external debt/GDP ratio, gross capital formation and import. The impact over growth in net FDI flow is positive but statistically insignificant.

After differencing once all series used in table 6.7 (a), VAR model indicates the results with stationary series of data which are indicated in table 6.7 (b). Although differencing of the series make most of the coefficients insignificant, it is still useful to find out the true sign of the impact of WTO_membership over yearly change in other variables. Because export has been twice-differenced to make it stationary, it does not make sense for interpretation. Here, positive impact of previous year's GDP growth is found again over its own value. Again, the impact of yearly import over yearly change in GDP growth, gross capital and import has been found higher if the state have sea borders. All coefficients of the binary variable WTO_MEMBERSHIP as the primary focus are statistically and insignificant. 
Table 6.7 (b) Panel VAR model results without contrubition of oil-and-gas

Vector Autoregression Estimates

Date: 18/12/13 Time: 03:20

Sample (adjusted): 19972012

Included observations: 48 after adjustments

Standard errors in ( )

\begin{tabular}{|c|c|c|c|c|c|c|}
\hline & $\begin{array}{c}\mathrm{D}(\mathrm{LOG}(\mathrm{GDP} \\
))\end{array}$ & $\begin{array}{l}\text { D(EXPORT, } \\
\text { 2) }\end{array}$ & $\begin{array}{c}\text {, D(DEBT_I } \\
\text { ATIO) }\end{array}$ & $\begin{array}{l}\text { D(GROSS_C } \\
\text { APITAL) }\end{array}$ & $\mathrm{D}(\mathrm{IMPORT})$ & $\begin{array}{c}\mathrm{D}(\mathrm{LOG}(\mathrm{NETF} \\
\mathrm{DI}))\end{array}$ \\
\hline $\mathrm{D}(\mathrm{LOG}(\mathrm{GDP}(-1)))$ & $\begin{array}{l}0.453758^{*} \\
(0.23232)\end{array}$ & $\begin{array}{c}-2.69 \mathrm{E}+08 \\
(3.2 \mathrm{E}+08)\end{array}$ & $\begin{array}{l}0.069834 \\
(0.18799)\end{array}$ & $\begin{array}{l}3.48 \mathrm{E}+08 \\
(9.9 \mathrm{E}+08)\end{array}$ & $\begin{array}{l}8.84 \mathrm{E}+08 \\
(5.8 \mathrm{E}+08)\end{array}$ & $\begin{array}{r}-1.222159 \\
(1.18879)\end{array}$ \\
\hline D(EXPORT(-1),2) & $\begin{array}{l}1.41 \mathrm{E}-11 \\
(5.4 \mathrm{E}-11)\end{array}$ & $\begin{array}{r}-0.028903 \\
(0.07427)\end{array}$ & $\begin{array}{c}-4.35 \mathrm{E}-11 \\
(4.4 \mathrm{E}-11)\end{array}$ & $\begin{array}{l}0.150289 \\
(0.23050)\end{array}$ & $\begin{array}{l}0.234661^{*} \\
(0.13516)\end{array}$ & $\begin{array}{l}7.43 \mathrm{E}-11 \\
(2.8 \mathrm{E}-10)\end{array}$ \\
\hline D(DEBT_RATIO(-1)) & $\begin{array}{r}-0.284835 \\
(0.31015)\end{array}$ & $\begin{array}{l}2.59 \mathrm{E}+08 \\
(4.3 \mathrm{E}+08)\end{array}$ & $\begin{array}{l}0.427861 \\
(0.25097)\end{array}$ & $\begin{array}{r}-1.24 \mathrm{E}+09 \\
(1.3 \mathrm{E}+09)\end{array}$ & $\begin{array}{l}3.37 \mathrm{E}+08 \\
(7.8 \mathrm{E}+08)\end{array}$ & $\begin{array}{r}-2.237128 \\
(1.58706)\end{array}$ \\
\hline D(GROSS_CAPITAL(-1)) & $\begin{array}{r}-5.81 \mathrm{E}-11 \\
(6.1 \mathrm{E}-11)\end{array}$ & $\begin{array}{c}-0.140164^{*} \\
(0.08374)\end{array}$ & $\begin{array}{l}1.49 \mathrm{E}-11 \\
(4.9 \mathrm{E}-11)\end{array}$ & $\begin{array}{r}-0.169783 \\
(0.25990)\end{array}$ & $\begin{array}{r}-0.027978 \\
(0.15240)\end{array}$ & $\begin{array}{l}2.65 \mathrm{E}-11 \\
(3.1 \mathrm{E}-10)\end{array}$ \\
\hline D(IMPORT(-1)) & $\begin{array}{r}-3.96 \mathrm{E}-11 \\
(5.1 \mathrm{E}-11)\end{array}$ & $\begin{array}{l}0.026929 \\
(0.07073)\end{array}$ & $\begin{array}{l}3.37 \mathrm{E}-12 \\
(4.1 \mathrm{E}-11)\end{array}$ & $\begin{array}{r}-0.064119 \\
(0.21950)\end{array}$ & $\begin{array}{r}-0.147892 \\
(0.12871)\end{array}$ & $\begin{array}{r}-1.00 \mathrm{E}-10 \\
(2.6 \mathrm{E}-10)\end{array}$ \\
\hline D(LOG(NETFDI(-1))) & $\begin{array}{r}-0.009096 \\
(0.02895)\end{array}$ & $\begin{array}{l}41834100 \\
(4.0 \mathrm{E}+07)\end{array}$ & $\begin{array}{l}0.008135 \\
(0.02342)\end{array}$ & $\begin{array}{l}18318848 \\
(1.2 \mathrm{E}+08)\end{array}$ & $\begin{array}{l}1737776 . \\
(7.3 \mathrm{E}+07)\end{array}$ & $\begin{array}{l}0.191597 \\
(0.14812)\end{array}$ \\
\hline $\mathrm{C}$ & $\begin{array}{l}0.091977 \\
(0.08852)\end{array}$ & $\begin{array}{l}61977658 \\
(1.2 \mathrm{E}+08)\end{array}$ & $\begin{array}{l}0.029570 \\
(0.07163)\end{array}$ & $\begin{array}{l}4.91 \mathrm{E}+08 \\
(3.8 \mathrm{E}+08)\end{array}$ & $\begin{array}{l}2.40 \mathrm{E}+08 \\
(2.2 \mathrm{E}+08)\end{array}$ & $\begin{array}{l}0.522197 \\
(0.45296)\end{array}$ \\
\hline \multicolumn{7}{|l|}{ D(EXPORT,2)*SEA_BOR } \\
\hline DER & $\begin{array}{c}-1.32 \mathrm{E}-10^{*} \\
(7.0 \mathrm{E}-11)\end{array}$ & $\begin{array}{l}0.827130^{* * *} \\
(0.09608)\end{array}$ & $\begin{array}{r}-2.51 \mathrm{E}-11 \\
(5.6 \mathrm{E}-11)\end{array}$ & $\begin{array}{r}-0.189783 \\
(0.29818)\end{array}$ & $\begin{array}{r}-0.037639 \\
(0.17484)\end{array}$ & $\begin{array}{l}9.67 \mathrm{E}-12 \\
(3.6 \mathrm{E}-10)\end{array}$ \\
\hline \multicolumn{7}{|l|}{ D(IMPORT)*SEA_BORD } \\
\hline $\mathrm{ER}$ & $\begin{array}{l}1.15 \mathrm{E}-10 \\
(3.7 \mathrm{E}-11)\end{array}$ & $\begin{array}{l}0.083497 \\
(0.05047)\end{array}$ & $\begin{array}{l}2.08 \mathrm{E}-12 \\
(3.0 \mathrm{E}-11)\end{array}$ & $\begin{array}{l}0.638957^{* * *} \\
(0.15663)\end{array}$ & $\begin{array}{l}1.003540^{* * *} \\
(0.09185)\end{array}$ & $\begin{array}{l}1.04 \mathrm{E}-10 \\
(1.9 \mathrm{E}-10)\end{array}$ \\
\hline \multicolumn{7}{|l|}{ LANDBORDER_COUNT } \\
\hline RIES & $\begin{array}{r}-0.009273 \\
(0.02228)\end{array}$ & $\begin{array}{c}-4639256 . \\
(3.1 \mathrm{E}+07)\end{array}$ & $\begin{array}{r}-0.006236 \\
(0.01802)\end{array}$ & $\begin{array}{r}-91293956 \\
(9.5 \mathrm{E}+07)\end{array}$ & $\begin{array}{r}-83279884 \\
(5.6 \mathrm{E}+07)\end{array}$ & $\begin{array}{r}-0.067537 \\
(0.11398)\end{array}$ \\
\hline WTO_MEMBERSHIP & $\begin{array}{l}0.017505 \\
(0.03926)\end{array}$ & $\begin{array}{r}-26715475 \\
(5.4 \mathrm{E}+07)\end{array}$ & $\begin{array}{r}-0.021710 \\
(0.03177)\end{array}$ & $\begin{array}{r}-1.26 \mathrm{E}+08 \\
(1.7 \mathrm{E}+08)\end{array}$ & $\begin{array}{l}1.09 \mathrm{E}+08 \\
(9.9 \mathrm{E}+07)\end{array}$ & $\begin{array}{l}0.000800 \\
(0.20092)\end{array}$ \\
\hline R-squared & 0.432673 & 0.926609 & 0.180392 & 0.640791 & 0.933767 & 0.212781 \\
\hline Adj. R-squared & 0.279341 & 0.906773 & -0.041124 & 0.543707 & 0.915866 & 0.000020 \\
\hline Sum sq. resids & 0.551656 & $1.05 \mathrm{E}+18$ & 0.361211 & $1.01 \mathrm{E}+19$ & $3.48 \mathrm{E}+18$ & 14.44451 \\
\hline S.E. equation & 0.122105 & $1.68 \mathrm{E}+08$ & 0.098805 & $5.23 \mathrm{E}+08$ & $3.07 \mathrm{E}+08$ & 0.624814 \\
\hline F-statistic & 2.821811 & 46.71477 & 0.814352 & 6.600408 & 52.16316 & 1.000092 \\
\hline Log likelihood & 39.07571 & -971.0857 & 49.23877 & -1025.447 & -999.8244 & -39.28777 \\
\hline Akaike AIC & -1.169821 & 40.92024 & -1.593282 & 43.18527 & 42.11768 & 2.095324 \\
\hline Schwarz SC & -0.741004 & 41.34905 & -1.164465 & 43.61409 & 42.54650 & 2.524140 \\
\hline Mean dependent & 0.126290 & 99954503 & 0.017889 & $3.90 \mathrm{E}+08$ & $5.88 \mathrm{E}+08$ & 0.169640 \\
\hline S.D. dependent & 0.143836 & $5.52 \mathrm{E}+08$ & 0.096834 & $7.74 \mathrm{E}+08$ & $1.06 \mathrm{E}+09$ & 0.624820 \\
\hline \multicolumn{7}{|c|}{ Determinant resid covariance (dof adj.) $1.97 \mathrm{E}+45$} \\
\hline \multicolumn{2}{|c|}{ Determinant resid covariance } & $4.12 \mathrm{E}+44$ & & & & \\
\hline \multicolumn{2}{|l|}{ Log likelihood } & -2874.180 & & & & \\
\hline \multicolumn{2}{|l|}{ Akaike information criterion } & 122.5075 & & & & \\
\hline \multicolumn{2}{|l|}{ Schwarz criterion } & 125.0804 & & & & \\
\hline
\end{tabular}

Note: *, ** and *** denote significance level of 10 percent, 5 percent and 1 percent levels, respectively. Source: Author's own creation. 


\section{With Contribution of Oil-and-Gas}

The results in table 6.8 (a) indicate VAR model coefficients which include GDP and export with the contribution of oil-and-gas. According to the table, previous year's GDP growth positively affects all other variable and all coefficients are statistically significant except the coefficient for external debt/GDP ratio. Unexpectedly, previous year's export is found to have negative and significant impact over GDP growth. Results indicate that previous year's import negatively affects the growth in amount of net FDI flow as well as gross capital formation. Moreover, previous year's growth in net FDI flow has positive and significant impact on its own value.

On the other hand, the change in external debt/GDP ratio affects negatively the growth in net FDI flow and positively its own value. Growth capital formation has positive and significant impact over import, the growth rate in net FD flow and its own value. According to the table, the impact of export is significantly higher over GDP growth, and significantly lower over growth in net FDI flow if the state has sea borders. Moreover, positive additional impact of import is found if the state has sear borders. Again interestingly, the effect of number of land border countries over export, import, growth in net FDI flow and gross capital formation is found statistically significant and negative.

The impact of WTO membership on other variables is only significant for GDP growth rate. This means that GDP growth rate in the countries of the panel has been $11.06 \%$ higher after their accession to WTO in comparison with pre accession period. Although all other coefficients are insignificant, WTO membership seems to affect positively the export, import and growth in net FDI flow and negatively the 
Table 6.8 (a) Panel VAR model results with contrubition of oil-and-gas

Vector Autoregression Estimates

Date: $18 / 12 / 13$ Time: 03:11

Sample (adjusted): 19952012

Included observations: 54 after adjustments

Standard errors in ()

\begin{tabular}{|c|c|c|c|c|c|c|}
\hline & & & & LOG(NETF & DEBT_RATI & I GROSS_CAPITA \\
\hline & LOG(GDP) & EXPORT & IMPORT & DI) & $\overline{\mathrm{O}}$ & $\overline{\mathrm{L}}$ \\
\hline LOG(GDP(-1)) & $\begin{array}{l}0.921571^{* * *} \\
(0.08810)\end{array}$ & $\begin{array}{l}5.18 \mathrm{E}+08^{* * *} \\
(1.8 \mathrm{E}+08)\end{array}$ & $\begin{array}{l}1.13 \mathrm{E}+09^{* * *} \\
(3.4 \mathrm{E}+08)\end{array}$ & $\begin{array}{l}1.224404^{* * *} \\
(0.37955)\end{array}$ & $\begin{array}{l}0.014534 \\
(0.05968)\end{array}$ & $\begin{array}{l}8.51 \mathrm{E}+08^{* *} \\
(3.7 \mathrm{E}+08)\end{array}$ \\
\hline EXPORT(-1) & $\begin{array}{l}-2.21 \mathrm{E}-11^{* *} \\
(9.6 \mathrm{E}-12)\end{array}$ & $\begin{array}{r}-0.011047 \\
(0.01987)\end{array}$ & $\begin{array}{r}-0.052217 \\
(0.03694)\end{array}$ & $\begin{array}{l}3.26 \mathrm{E}-12 \\
(4.1 \mathrm{E}-11)\end{array}$ & $\begin{array}{r}-4.28 \mathrm{E}-12 \\
(6.5 \mathrm{E}-12)\end{array}$ & $\begin{array}{l}0.002847 \\
(0.04060)\end{array}$ \\
\hline IMPORT(-1) & $\begin{array}{r}-2.62 \mathrm{E}-11 \\
(4.1 \mathrm{E}-11)\end{array}$ & $\begin{array}{r}-0.039571 \\
(0.08571)\end{array}$ & $\begin{array}{r}-0.091297 \\
(0.15934)\end{array}$ & $\begin{array}{l}-6.18 \mathrm{E}-10^{* * *} \\
(1.8 \mathrm{E}-10)\end{array}$ & $\begin{array}{l}2.78 \mathrm{E}-11 \\
(2.8 \mathrm{E}-11)\end{array}$ & $\begin{array}{l}-0.547188^{* * *} \\
(0.17510)\end{array}$ \\
\hline LOG(NETFDI(-1)) & $\begin{array}{l}0.024998 \\
(0.02219)\end{array}$ & $\begin{array}{l}3337669 . \\
(4.6 \mathrm{E}+07)\end{array}$ & $\begin{array}{r}-79611305 \\
(8.5 \mathrm{E}+07)\end{array}$ & $\begin{array}{l}0.398685^{* * *} \\
(0.09560)\end{array}$ & $\begin{array}{r}-0.003229 \\
(0.01503)\end{array}$ & $\begin{array}{r}-13942408 \\
(9.4 \mathrm{E}+07)\end{array}$ \\
\hline DEBT_RATIO(-1) & $\begin{array}{r}-0.139496 \\
(0.14501)\end{array}$ & $\begin{array}{l}1.51 \mathrm{E}+08 \\
(3.0 \mathrm{E}+08)\end{array}$ & $\begin{array}{r}-72651010 \\
(5.6 \mathrm{E}+08)\end{array}$ & $\begin{array}{c}-1.265163^{* *} \\
(0.62473)\end{array}$ & $\begin{array}{l}0.862661^{* * *} \\
(0.09824)\end{array}$ & $\begin{array}{l}72366132 \\
(6.1 \mathrm{E}+08)\end{array}$ \\
\hline GROSS_CAPITAL(-1) & $\begin{array}{l}1.25 \mathrm{E}-11 \\
(4.5 \mathrm{E}-11)\end{array}$ & $\begin{array}{l}0.113204 \\
(0.09285)\end{array}$ & $\begin{array}{l}0.403262^{* *} \\
(0.17261)\end{array}$ & $\begin{array}{l}3.23 \mathrm{E}-10^{*} \\
(1.9 \mathrm{E}-10)\end{array}$ & $\begin{array}{r}-6.22 \mathrm{E}-12 \\
(3.0 \mathrm{E}-11)\end{array}$ & $\begin{array}{l}0.971334^{* * *} \\
(0.18968)\end{array}$ \\
\hline $\mathrm{C}$ & $\begin{array}{l}1.478047 \\
(1.74609)\end{array}$ & $\begin{array}{l}-9.85 \mathrm{E}+09^{* * *} \\
(3.6 \mathrm{E}+09)\end{array}$ & $\begin{array}{c}{ }^{*}-1.99 \mathrm{E}+10^{* * * *} \\
(6.7 \mathrm{E}+09)\end{array}$ & $\begin{array}{c}-13.37470^{*} \\
(7.52254)\end{array}$ & $\begin{array}{r}-0.137446 \\
(1.18287)\end{array}$ & $\begin{array}{c}-1.63 \mathrm{E}+10^{* *} \\
(7.4 \mathrm{E}+09)\end{array}$ \\
\hline $\begin{array}{l}\text { EXPORT*SEA_BORDH } \\
\mathrm{R}\end{array}$ & $\begin{array}{l}\text { E } \\
2.25 \mathrm{E}-11^{* *} \\
(1.0 \mathrm{E}-11)\end{array}$ & $\begin{array}{l}1.015063^{* * *} \\
(0.02063)\end{array}$ & $\begin{array}{l}0.015162 \\
(0.03834)\end{array}$ & $\begin{array}{l}-8.89 \mathrm{E}-11^{* *} \\
(4.3 \mathrm{E}-11)\end{array}$ & $\begin{array}{r}-5.03 \mathrm{E}-12 \\
(6.8 \mathrm{E}-12)\end{array}$ & $\begin{array}{l}0.022839 \\
(0.04214)\end{array}$ \\
\hline $\begin{array}{l}\text { IMPORT*SEA_BORDE } \\
\mathrm{R}\end{array}$ & $\begin{array}{l}2.27 \mathrm{E}-11 \\
(2.3 \mathrm{E}-11)\end{array}$ & $\begin{array}{l}-0.168906^{* * *} \\
(0.04684)\end{array}$ & $\begin{array}{l}0.660314^{* * *} \\
(0.08708)\end{array}$ & $\begin{array}{l}3.73 \mathrm{E}-10^{* * *} \\
(9.8 \mathrm{E}-11)\end{array}$ & $\begin{array}{r}-2.26 \mathrm{E}-12 \\
(1.5 \mathrm{E}-11)\end{array}$ & $\begin{array}{l}0.320629^{* * *} \\
(0.09569)\end{array}$ \\
\hline $\begin{array}{l}\text { LANDBORDER_COUN } \\
\text { TRIES }\end{array}$ & $\begin{array}{r}\mathrm{N} \\
-0.029386 \\
(0.03312)\end{array}$ & $\begin{array}{c}-3.63 \mathrm{E}+08^{* * *} \\
(6.8 \mathrm{E}+07)\end{array}$ & $\begin{array}{c}{ }^{*}-7.57 \mathrm{E}+08^{* * *} \\
(1.3 \mathrm{E}+08)\end{array}$ & $\begin{array}{l}-0.280915^{*} \\
(0.14268)\end{array}$ & $\begin{array}{r}-0.022271 \\
(0.02243)\end{array}$ & $\begin{array}{l}-4.05 \mathrm{E}+08^{* * *} \\
(1.4 \mathrm{E}+08)\end{array}$ \\
\hline WTO_MEMBERSHIP & $\begin{array}{l}0.110674^{*} \\
(0.06128)\end{array}$ & $\begin{array}{l}1.39 \mathrm{E}+08 \\
(1.3 \mathrm{E}+08)\end{array}$ & $\begin{array}{l}2.43 \mathrm{E}+08 \\
(2.4 \mathrm{E}+08)\end{array}$ & $\begin{array}{l}0.057486 \\
(0.26400)\end{array}$ & $\begin{array}{r}-0.036796 \\
(0.04151)\end{array}$ & $\begin{array}{r}-43244446 \\
(2.6 \mathrm{E}+08)\end{array}$ \\
\hline $\begin{array}{l}\text { R-squared } \\
\text { Adj. R-squared } \\
\text { Sum sq. resids } \\
\text { S.E. equation } \\
\text { F-statistic } \\
\text { Log likelihood } \\
\text { Akaike AIC } \\
\text { Schwarz SC } \\
\text { Mean dependent } \\
\text { S.D. dependent }\end{array}$ & $\begin{array}{r}0.985060 \\
0.981585 \\
0.768727 \\
0.133706 \\
283.5147 \\
38.18142 \\
-1.006719 \\
-0.601556 \\
22.58821 \\
0.985304\end{array}$ & $\begin{array}{c}0.999346 \\
0.999195 \\
3.28 \mathrm{E}+18 \\
2.76 \mathrm{E}+08 \\
6575.535 \\
-1120.063 \\
41.89121 \\
42.29637 \\
5.30 \mathrm{E}+09 \\
9.73 \mathrm{E}+09\end{array}$ & $\begin{array}{c}0.985297 \\
0.981877 \\
1.13 \mathrm{E}+19 \\
5.14 \mathrm{E}+08 \\
288.1495 \\
-1153.544 \\
43.13126 \\
43.53643 \\
4.12 \mathrm{E}+09 \\
3.81 \mathrm{E}+09\end{array}$ & $\begin{array}{r}0.888063 \\
0.862031 \\
14.26822 \\
0.576037 \\
34.11436 \\
-40.68705 \\
1.914335 \\
2.319499 \\
19.93738 \\
1.550813\end{array}$ & $\begin{array}{r}0.867049 \\
0.836130 \\
0.352791 \\
0.090578 \\
28.04266 \\
59.21060 \\
-1.785578 \\
-1.380415 \\
0.414496 \\
0.223756\end{array}$ & $\begin{array}{c}0.969388 \\
0.962269 \\
1.37 \mathrm{E}+19 \\
5.64 \mathrm{E}+08 \\
136.1694 \\
-1158.638 \\
43.31992 \\
43.72508 \\
2.76 \mathrm{E}+09 \\
2.91 \mathrm{E}+09\end{array}$ \\
\hline $\begin{array}{l}\text { Determinant resid covar } \\
\text { Determinant resid covar } \\
\text { Log likelihood } \\
\text { Akaike information crit } \\
\text { Schwarz criterion }\end{array}$ & $\begin{array}{lr}\text { riance (dof adj. } \\
\text { riance } & 1 . \\
& -32 \\
\text { erion } & 12 \\
& 12\end{array}$ & $\begin{array}{l}\text {.) } 4.55 \mathrm{E}+45 \\
.16 \mathrm{E}+45 \\
261.364 \\
23.2357 \\
25.6667\end{array}$ & & & & \\
\hline
\end{tabular}

Note: *,** and *** denote significance level of 10 percent, 5 percent and 1 percent levels, respectively.

Source: Author's own creation 
external debt/GDP ratio and gross capital formation. Interestingly, this insignificant impact is 1.74 times $(2.43 \mathrm{E}+08 / 1.39 \mathrm{E}+08)$ higher over import in comparison the export.

On the other hand, table 6.8 (b) represents the results of panel VAR model which cover contribution of oil-and-gas as well. According to the table, in short, only a few coefficients are statistically significant. Yearly change in previous year's external debt/GAT ratio statistically significantly and positively affects the change in its own value. Moreover, the impact of yearly change in previous year's gross capital formation over yearly change in export is also found statistically significant at $10 \%$ which is negative. In addition, results indicate that the impact of yearly change in import over yearly change in amount of gross capital formation is higher if the state has sea borders. In this table, the impact of amount of land border countries which the borders are open to economic transactions is found negative over export and import. None of the coefficients at WTO_membership is statistically significant. However, the sign of coefficients is positive for yearly change in GDP growth, export and import and negative for yearly change in growth of net FDI flow, external debt/GDP ratio and gross capital formation.

Despite of differences in WTO_membership coefficients, general conclusion implies that we have not enough evidence to claim that accession to WTO has been good for Georgia and Armenia. Panel VAR models also fails to find significant impact of WTO membership over included macroeconomic indicators. 
Table 6.8 (b) Panel VAR model results with contrubition of oil-and-gas

Vector Autoregression Estimates

Date: 18/12/13 Time: 03:16

Sample (adjusted): 19962012

Included observations: 51 after adjustments

Standard errors in ( )

\begin{tabular}{|c|c|c|c|c|c|c|}
\hline & \multicolumn{3}{|c|}{ D(LOG(GDP } & \multicolumn{3}{|c|}{ D(LOG(NETD(DEBT_RATD(GROSS_CAPI } \\
\hline & )$)$ & D(EXPORT) & $\mathrm{D}(\mathrm{IMPORT})$ & FDI) & IO) & TAL) \\
\hline $\mathrm{D}(\mathrm{LOG}(\mathrm{GDP}(-1)))$ & $\begin{array}{l}0.266036 \\
(0.25034)\end{array}$ & $\begin{array}{r}-2.16 \mathrm{E}+08 \\
(2.5 \mathrm{E}+08)\end{array}$ & $\begin{array}{l}3.31 \mathrm{E}+08 \\
(6.0 \mathrm{E}+08)\end{array}$ & $\begin{array}{r}-0.885915 \\
(1.27352)\end{array}$ & $\begin{array}{l}0.181394 \\
(0.18025)\end{array}$ & $\begin{array}{r}-4.07 \mathrm{E}+08 \\
(9.8 \mathrm{E}+08)\end{array}$ \\
\hline D(EXPORT(-1)) & $\begin{array}{l}9.58 \mathrm{E}-13 \\
(1.1 \mathrm{E}-11)\end{array}$ & $\begin{array}{l}0.015010 \\
(0.01056)\end{array}$ & $\begin{array}{l}0.007956 \\
(0.02546)\end{array}$ & $\begin{array}{l}2.10 \mathrm{E}-11 \\
(5.4 \mathrm{E}-11)\end{array}$ & $\begin{array}{r}-1.20 \mathrm{E}-11 \\
(7.6 \mathrm{E}-12)\end{array}$ & $\begin{array}{l}0.058017 \\
(0.04146)\end{array}$ \\
\hline D(IMPORT(-1)) & $\begin{array}{r}-2.61 \mathrm{E}-12 \\
(4.2 \mathrm{E}-11)\end{array}$ & $\begin{array}{l}0.027378 \\
(0.04209)\end{array}$ & $\begin{array}{r}-0.047638 \\
(0.10146)\end{array}$ & $\begin{array}{r}-2.67 \mathrm{E}-10 \\
(2.1 \mathrm{E}-10)\end{array}$ & $\begin{array}{l}1.68 \mathrm{E}-11 \\
(3.0 \mathrm{E}-11)\end{array}$ & $\begin{array}{r}-0.077925 \\
(0.16524)\end{array}$ \\
\hline D(LOG(NETFDI(-1))) & $\begin{array}{l}0.004155 \\
(0.02430)\end{array}$ & $\begin{array}{l}10667310 \\
(2.4 \mathrm{E}+07)\end{array}$ & $\begin{array}{l}16726424 \\
(5.9 \mathrm{E}+07)\end{array}$ & $\begin{array}{l}0.095823 \\
(0.12363)\end{array}$ & $\begin{array}{r}-0.001379 \\
(0.01750)\end{array}$ & $\begin{array}{l}31468590 \\
(9.5 \mathrm{E}+07)\end{array}$ \\
\hline D(DEBT_RATIO(-1)) & $\begin{array}{r}-0.517469 \\
(0.32073)\end{array}$ & $\begin{array}{r}-2.91 \mathrm{E}+08 \\
(3.2 \mathrm{E}+08)\end{array}$ & $\begin{array}{r}-24741938 \\
(7.7 \mathrm{E}+08)\end{array}$ & $\begin{array}{r}-2.599889 \\
(1.63166)\end{array}$ & $\begin{array}{l}0.486465^{* *} \\
(0.23094)\end{array}$ & $\begin{array}{r}-1.95 \mathrm{E}+09 \\
(1.3 \mathrm{E}+09)\end{array}$ \\
\hline D(GROSS_CAPITAL( & & & & & & \\
\hline-1$))$ & $\begin{array}{r}-5.36 \mathrm{E}-11 \\
(6.2 \mathrm{E}-11)\end{array}$ & $\begin{array}{c}-0.107541^{*} \\
(0.06246)\end{array}$ & $\begin{array}{r}-0.014807 \\
(0.15056)\end{array}$ & $\begin{array}{l}1.11 \mathrm{E}-10 \\
(3.2 \mathrm{E}-10)\end{array}$ & $\begin{array}{l}4.09 \mathrm{E}-12 \\
(4.5 \mathrm{E}-11)\end{array}$ & $\begin{array}{r}-0.088208 \\
(0.24520)\end{array}$ \\
\hline $\mathrm{C}$ & $\begin{array}{l}0.089219 \\
(0.08830)\end{array}$ & $\begin{array}{l}2.52 \mathrm{E}+08^{* * *} \\
(8.8 \mathrm{E}+07)\end{array}$ & $\begin{array}{l}3.10 \mathrm{E}+08 \\
(2.1 \mathrm{E}+08)\end{array}$ & $\begin{array}{l}0.453097 \\
(0.44919)\end{array}$ & $\begin{array}{l}0.016065 \\
(0.06358)\end{array}$ & $\begin{array}{l}5.52 \mathrm{E}+08 \\
(3.5 \mathrm{E}+08)\end{array}$ \\
\hline $\begin{array}{l}\text { D(EXPORT)*SEA_B } \\
\text { ORDER }\end{array}$ & $\begin{array}{l}1.77 \mathrm{E}-11 \\
(1.2 \mathrm{E}-11)\end{array}$ & $\begin{array}{l}1.002169^{* * *} \\
(0.01179)\end{array}$ & $\begin{array}{r}-0.003332 \\
(0.02841)\end{array}$ & $\begin{array}{r}-4.85 \mathrm{E}-11 \\
(6.0 \mathrm{E}-11)\end{array}$ & $\begin{array}{r}-4.96 \mathrm{E}-12 \\
(8.5 \mathrm{E}-12)\end{array}$ & $\begin{array}{l}0.000826 \\
(0.04628)\end{array}$ \\
\hline $\begin{array}{l}\text { D(IMPORT)*SEA_B } \\
\text { ORDER }\end{array}$ & $\begin{array}{l}2.41 \mathrm{E}-11 \\
(3.5 \mathrm{E}-11)\end{array}$ & $\begin{array}{r}-0.011343 \\
(0.03515)\end{array}$ & $\begin{array}{l}1.006618^{* * *} \\
(0.08472)\end{array}$ & $\begin{array}{l}1.99 \mathrm{E}-10 \\
(1.8 \mathrm{E}-10)\end{array}$ & $\begin{array}{l}4.39 \mathrm{E}-12 \\
(2.5 \mathrm{E}-11)\end{array}$ & $\begin{array}{l}0.530905^{* * *} \\
(0.13797)\end{array}$ \\
\hline $\begin{array}{l}\text { LANDBORDER_CO } \\
\text { UNTRIES }\end{array}$ & $\begin{array}{r}-0.001765 \\
(0.02200)\end{array}$ & $\begin{array}{l}-55940492^{* *} \\
(2.2 \mathrm{E}+07)\end{array}$ & $\begin{array}{c}-96072291^{*} \\
(5.3 \mathrm{E}+07)\end{array}$ & $\begin{array}{r}-0.024062 \\
(0.11191)\end{array}$ & $\begin{array}{r}-0.003699 \\
(0.01584)\end{array}$ & $\begin{array}{r}-95116283 \\
(8.6 \mathrm{E}+07)\end{array}$ \\
\hline WTO_MEMBERSHIP & $\begin{array}{l}0.028126 \\
(0.04340)\end{array}$ & $\begin{array}{l}33887762 \\
(4.3 \mathrm{E}+07)\end{array}$ & $\begin{array}{l}1.14 \mathrm{E}+08 \\
(1.0 \mathrm{E}+08)\end{array}$ & $\begin{array}{r}-0.046292 \\
(0.22076)\end{array}$ & $\begin{array}{r}-0.033260 \\
(0.03125)\end{array}$ & $\begin{array}{r}-59629529 \\
(1.7 \mathrm{E}+08)\end{array}$ \\
\hline $\begin{array}{l}\text { R-squared } \\
\text { Adj. R-squared } \\
\text { Sum sq. resids } \\
\text { S.E. equation } \\
\text { F-statistic } \\
\text { Log likelihood } \\
\text { Akaike AIC } \\
\text { Schwarz SC } \\
\text { Mean dependent } \\
\text { S.D. dependent }\end{array}$ & $\begin{array}{c}0.450878 \\
0.313597 \\
0.652656 \\
0.127736 \\
3.284351 \\
38.77665 \\
-1.089281 \\
-0.672612 \\
0.132786 \\
0.154178\end{array}$ & $\begin{array}{c}0.998467 \\
0.998083 \\
6.52 \mathrm{E}+17 \\
1.28 \mathrm{E}+08 \\
2604.712 \\
-1018.092 \\
40.35654 \\
40.77321 \\
9.17 \mathrm{E}+08 \\
2.92 \mathrm{E}+09\end{array}$ & $\begin{array}{c}0.928981 \\
0.911227 \\
3.79 \mathrm{E}+18 \\
3.08 \mathrm{E}+08 \\
52.32313 \\
-1062.963 \\
42.11620 \\
42.53287 \\
5.60 \mathrm{E}+08 \\
1.03 \mathrm{E}+09\end{array}$ & $\begin{array}{c}0.263438 \\
0.079297 \\
16.89089 \\
0.649825 \\
1.430635 \\
-44.18706 \\
2.164199 \\
2.580867 \\
0.208359 \\
0.677231\end{array}$ & $\begin{array}{r}0.205468 \\
0.006835 \\
0.338374 \\
0.091975 \\
1.034413 \\
55.52761 \\
-1.746181 \\
-1.329513 \\
0.017156 \\
0.092291\end{array}$ & $\begin{array}{c}0.644991 \\
0.556239 \\
1.01 \mathrm{E}+19 \\
5.01 \mathrm{E}+08 \\
7.267334 \\
-1087.837 \\
43.09167 \\
43.50833 \\
3.81 \mathrm{E}+08 \\
7.53 \mathrm{E}+08\end{array}$ \\
\hline $\begin{array}{l}\text { Determinant resid cova } \\
\text { Determinant resid cova } \\
\text { Log likelihood } \\
\text { Akaike information cri } \\
\text { Schwarz criterion }\end{array}$ & $\begin{array}{l}\text { ariance (dof } \\
\text { ariance } \\
\text { iterion }\end{array}$ & $\begin{array}{l}\text { dj.) } 1.10 \mathrm{E}+45 \\
2.55 \mathrm{E}+44 \\
-3041.561 \\
121.8651 \\
124.3651\end{array}$ & & & & \\
\hline
\end{tabular}

Note: *** and *** denote significance level of 10 percent, 5 percent and 1 percent levels, respectively.

Source: Author's own creation 


\section{Chapter 7}

\section{CONCLUSION}

This thesis is aimed to analyze expected impacts of accession to WTO on Azerbaijan economy. In the second chapter, a comprehensive analyze of WTO is done, purposed to ensure better understanding of this organization in terms of what may be expected or does the expectations in Azerbaijan, today, is possible to happen in case of its accession to WTO. After all, it is concluded that WTO is just an organization and all things are depend on the results of negotiations between states themselves. In this sense, accession to WTO should not be considered as a "miracle" to solve many problems in Azerbaijan economy.

In the third chapter, I looked through previous research related to the impact of WTO on international trade and economies of the member countries and the impact of trade liberalization as a cause of WTO membership over economic growth performance of the countries. Many studies done by both critics and supporters of the organization are covered. However, there is not any commonly adopted view that the results of those studies differs regard to the approach, classification and type of the applied model.

In the fourth chapter, I analyzed macroeconomic performance of Azerbaijan economy during the transition period with both oil-and-gas and none oil-and-gas context as well as the economy of Georgia and Armenia in before-and-after WTO 
membership context. It is concluded that the dependence of Azerbaijan economy, especially export from oil-and-gas industry is seriously high and this will continue in the near future as well due to present oil and expected gas production. After discussing trends in Georgia and Armenia economies before-and-after WTO membership, graphically, I concluded that there an increase especially in export and import of this countries after their accession to WTO. However, the increase is considerable higher than the increase in export and this gap is seriously high.

The fifth chapter was devoted to the discussing the data and methodology which has been used in this thesis. Here, I decided to use the case study and VAR model. VAR model was applied to the non-stationary and stationary (after differencing once) data for Georgia and Armenia, individually, and panel data with and without the oil-andgas contribution. Therefore, eight different VAR model regression were defined to estimate which all included the binary variable WTO_membership. In the sixth chapter, I interpreted the results and concluded that:

For Georgia, with non-stationary or I(1) series of data, I found seriously significant and positive impacts of WTO_membership. However, with non-stationary data attained after differencing once of the time series used in the previous model, I find statistically significant the impact of WTO membership only for yearly change in GDP growth which is positive. The impact for yearly change in import and export was found positive and negative, respectively, and statistically insignificant for both of them. Because the cointegration was unable to apply due to insufficient number of observations, results of the model with non-stationary series of data seems suspicious and consequently, results of the second one is taken as a basis in this analysis. 
For Armenia, with non-stationary or original series of data, the impact of WTO_membership was found statistically insignificant at all for all variables in the model. Interestingly, the sign of the coefficient is negative for all except the export. However, VAR model results for Armenia with stationary series of data achieved through differencing once the original data as well, the impact of WTO_membership is found only statistically significant and positive for import and export which the impact over import is 2.15 times of the impact on export. The impact for GDP growth was found positive but statistically insignificant. Because of the same issue, I will take the results of the model for Armenia with stationary series of data as a basis in this analysis.

For panel VAR models, with non-stationary series of data without contribution of oil-and-gas, the impact was found only statistically significant and positive for GDP growth. Remaining coefficients are all statistically insignificant and negative except for growth in net FDI flow. After differencing once to make the data stationary, all coefficients is found statistically insignificant which implies that WTO membership does not matter so much. In the panel VAR models with non-stationary data which also cover the contribution of oil-and-gas, the impact was found statistically significant and positive for only GDP growth. Interestingly, the coefficients at import is higher than at export which implies that WTO membership increases import much more than export but, none of them are statistically significant. In this model as well, after differencing once, none of the coefficients at WTO became statistically significant but, the coefficient at import still exceeds the coefficient at export. This also implies that WTO membership does not matter for economies of member countries so much. However, it increases import much more than export which 
causes to the increasing of foreign trade deficit and is considered as "bad" in basic rules context of P. Krugman.

\subsection{To Join or Not to Join? Policy Recommendations for Azerbaijan}

Making a decision to join or not to join to WTO would have both advantages and disadvantages for the economy of Azerbaijan. Today, there are several expectations in Azerbaijan society from accession to WTO such as decreasing or eliminating of monopoly in the economy, developing non-oil sector, increasing non-oil export and etc. Moreover, WTO membership would ensure a status and become an indicator of integration and tendency to liberalization from the international view. Nevertheless, neither membership status, nor change in the view of international organizations should affect the joining decision as much as expected macroeconomic impacts did.

Opposite to the expectations, membership does not solve the monopoly issue what we see in Armenia case. In addition, to take trade disputes to WTO DSB is not effective for a small developing economy such as Azerbaijan which is obvious from statistics of cases brought to DSB. Moreover, Azerbaijan will never use balance of payments concessions within at least next twenty years because of oil and gas export which always results trade surplus. Membership will not affect export seriously because, Azerbaijan's export is mostly consisted of oil and gas which are not under the control of WTO. Revenues from oil and gas sector will always have an increasing pressure on Azerbaijan currency, manat which will make non-oil-and-gas export less competitive in international markets.

On the other hand, import is a function of national income and after the membership, import may be expected to increase significantly in light of Azerbaijan's increasing 
GDP. Azerbaijan's internal market still does not know enough what to do in case of strong competition from marketing experience, technology and cost of production perspectives. Especially, Azerbaijan's agriculture sector is based on mostly individual farming which employs significant part of the labor force. In this sense, expectations on positive impacts of the WTO membership seems less rational.

Empirical part of this thesis also failed to find enough evidence that the impact of WTO membership may be positive. Opposite, both graphical and empirical analysis produced the same results that the membership increases import considerable more than export. This raises the question why to join if a country will buy more than its selling after the accession. Moreover, expectations about increasing net FDI flow to the country is also failed to find enough evidence. In fact, FDI flow is not a direct function of WTO membership that the conditions to attract FDIs may be created without the accession.

To conclude, there is not enough evidence to say that it is better for Azerbaijan economy to join to WTO. That is why, Azerbaijan must insist on its arguments in bilateral and multilateral negotiations and demonstrate that it can accomplish to its economic targets without WTO membership. Alternatives such as signing bilateral trade contracts out of the negotiations for WTO membership or establishing a special economic zone in accordance with world experience may be better for Azerbaijan economy that the membership at WTO. 


\section{REFERENCES}

Akhundov, A. (2012). Deputy Minister: Azerbaijan should not Cooperate with Armenia in Case of WTO Accession, TREND News Agency, Retrieved

December http://en.trend.az/capital/business/2098163.html, (Reached at December 14, 2013).

Alt, J. E., \& Gilligan, M. (2000). The Political Economy of Trading States: Factor Specificity, Collective Action Problems, and Domestic Political Institutions, in Frieden, J. A., \& Lake, D. A. International Political Economy: Perspectives on Global Power and Wealth, Wadsworth/Thomson learning Inc., 327-342.

Allee, T. L., \& Scalera, J. E. (2012). The Divergent Effects of Joining International Organizations: Trade Gains and the Rigors of WTO Accession. International Organization. 64: 2, 243-276.

Anderson, K. (2010). Can the WTO Reduce Agricultural Trade Distortions? The Journal of International Trade \& Economic Development, 19:1, 109-134.

Aras, O. N., \& Suleymanov, E. (2012). The Importance of Azerbaijan's Energy Revenues in its Exports Volume and the Effects on the National Economy, in International Conference on Eurasian Economies 11-13 October 2012 Almaty, Kazakhstan, 225-232. 
Aslund, A., Boone, P., \& Johnson ,S. (1996). How to Stabilize: Lessons from PostCommunist Countries. Brookings Papers on Economic Activity. 1, pp. 217312.

Azerbaijan and WTO. (2013). http://wto.az (Reached atJuly 20, 2013)

Bagwell, K., \& Staiger, R. W. (2003). Economic Theory and the Interpretation of GATT/WTO, August http://www.ssc.wisc.edu/ rstaiger/econ.theory.gatt.wto.pdf(Reached at December 15, 2013)

Bagwell, K., \& Staiger, R. (1999). An Economic Theory of GATT. American Economic Review, 89:1, 215-248.

Balding, C. (2010). Joining the World Trade Organization: What is the Impact? Review of International Economics, 18: 1, 193-206.

Bank, W.

2013.http://www.worldbank.org/en/country/azerbaijan/projects/all?qterm=\&la $\underline{\text { ng exact }=\text { English\&os=20 }}$ (Reached at December 19, 2013)

Bank, W. (2013).http://data.worldbank.org(Reached at July 2013)

Bank, W. (2008). Privatization and Corruption: The World Bank and Azerbaijan. http://www.whistleblower.org/storage/documents/Privatization_and_Corrupti on.pdf (Reached at May 22, 2013) 
Bank, W. (1995). Statistical Handbook 1995: States of the Former USSR, World Bank, Studies of Economies in Transformation, December.

Baranick, M. J., \& Salayeva, R. (2005). State-Building in a Transition Period: The Case of Azerbaijan. The Cornwallis Group X: Analysis for New and Emerging Societal Conflict, p. 213.

Bayramov, V. (2008). A Comparative Analysis of CIS Countries' WTO Accession; Ways to European Integration. http://siteresources.worldbank.org/INTRAD/Resources/Bayramov.pdf (Reached at July 14, 2013)

Bayulgen, O. (2003). Facing the dilemma of global capitalism: the case of Azerbaijan. Central Asian Survey, 22: 2/3, June/September, p. 209.

Boyarchuk, D. (2012). Azerbaijan's Fiscal Policy after the Oil Boom. CASE Network E-briefsNo. 02/2012, Center for Social and Economic research (CASE).

Bulut, C. (2007). The Evaluation of Azerbaijan's WTO Accession. Gazi Üniversitesi Iktisadi ve Idari Bilimler Fakültesi Dergisi. 9: 2, 59-73.

Buthe, T., \& Milner, H. V. (2008). The Politics of Foreign Direct Investment into Developing Countries: Increasing FDI through International Trade Agreements? American Journal of Political Science, 52:4, 741-762. 
CESD. (2012a). Azerbaijan may Join the WTO in 2013 if Government of Azerbaijan Speed up Membership Negotiations. http://cesd.az/new/2012/05/azerbaijanmay-join-the-wto-in-2013/ (Reached at December 20, 2013)

CESD. (2012b). What new WTO Negotiations Promise? http://cesd.az/new/2012/12/what-new-wto-negotiations-promise/(Reached at December 20, 2013)

CESD. (2013). New WTO Accession Negotiations: New Hopes? http://cesd.az/new/2013/05/new-wto-accession-negotiations-newhopes/(Reached at November 20, 2013)

Ciarreta, A., \& Nasirov, S. (2012). Development Trends in the Azerbaijan Oil and Gas Sector: Achievements and Challenges. Energy Policy, 40, 282-292.

CIA. (2013). https://www.cia.gov/library/publications/the-worldfactbook/rankorder/2079rank.html (Reached at December 20, 2013)

Chang, R., Kaltani, L., \& Loayza, N. (2009). Openness can Be Good for Growth: The Role of Policy Complementarities. Journal of Development Economics. 90: $1,33-49$.

Chang, P., \& Lee, M. (2011). The WTO Trade Effect. Journal of International Economics. 85: 1, 53-71. 
Chorev. N. (2005). The Institutional Project of Neo-Liberal Globalism: The Case of the WTO. Theory and Society. 34:3, 317-355.

Cornell, S. E., \& Ismailzade, F. (2005). The Baku-Tbilisi-Ceyhan Pipeline: Implications for Azerbaijan, in Starr, S. F., \& Cornell, S. E. The Baku-TbilisiCeyhan Pipeline: Oil Window to the West, Central Asia-Caucasus Institute \& Silk Road Studies Program, 61-85.

Dąbrowski, M. (2003). Disinflation Strategies in Transition Economies and Their Effectiveness, in Dabrowski, M. Disinflation in Transition Economies, Central European University Press.

Dowrick, S., \& Golley, J. (2004). Trade Openness and Growth: Who Benefits? Oxford Review of Economic Policy, 20:1, 38-56

Dudwick, N., Fock, K.\& Sedik, D. (2007). Land Reform and Farm Restructuring in Transition Countries: The Experience of Bulgaria, Moldova, Azerbaijan, and Kazakhstan, World Bank Publications

Dutt, P., Zandt, T. V., \& Mihov, I. (2013), The Effect of WTO on the Extensive and the Intensive Margins of Trade, February. http://www.freit.org/WorkingPapers/Papers/TradePolicyMultilateral/FREIT5 15.pdf (Reached at December 14, 2014) 
EBRD. Transition Report, 2005: Business in Transition.

http://www.ebrd.com/downloads/research/transition/TR05.pdf (Reached at June 10, 2013)

Edwards, S. (1998). Openness, Productivity and Growth: What do We Really Know? The Economic Journal, 108:447, 383-398.

Eicher, T. S., \& Henn, C. (2011). In Search of WTO Trade Effects: Preferential Trade Agreements Promote Trade Strongly, but Unevenly. Journal of International Economics. 83: 2, 137-153.

Eromenko, I. (2010). Accession to the WTO: Part I, Igor Eromenko \& Ventus Publishing ApS.

ESCAP. (2001). Accession to the World Trade Organization: Issues and Recommendations for Central Asian and Caucasian Economies in Transition, United Nations Publication.

Escudero, S. T. (2009). Azerbaijan: A Strong Fiscal Policy, in Triller, E. Azerbaijan and the Global Economic Crisis: Sustaining Stability, Impact Azerbaijan, pp. 8-12.

Fieleke, N. S. (1995). The Uruguay Round of Negotiations: an Overview. New England Economic Review. May/June. 
Fletcher, I. (2010). Dubious Assumptions of the Theory of Comparative Advantage. Real-World Economics Review. 54, 94-105.

Ford, J. (2002). A Social Theory of Trade Regime Change: GATT to WTO. International Studies Review.4: 3, 115-138.

Frankel, J. A., \& Romer, D. (1996). Trade and Growth: An Empirical Investigation. Working Paper 5476, National Bureau of Economic Research.

GATS.

http://www.wto.org/english/res_e/booksp_e/analytic_index_e/gats_01_e.htm\# $\underline{\operatorname{article} 1 \mathrm{~A}}($ Reached at July 20, 2013)

GATT. (1994).

http://www.wto.org/english/res_e/booksp_e/analytic_index_e/gatt1994_01_e. $\underline{\text { htm\#p }}$ (Reached at December 19, 2013)

Gowa, J., \& Kim, S. Y. (2005). An Exclusive Country Club: The Effects of the GATT on Trade, 1950-94. World Politics. 57: 4, 453-478.

Grant, J. H., \& Boys, K.A. (2012). Agricultural Trade and the GATT/WTO: Does Membership Make A Difference? American Journal of Agricultural Economics. 94: 1, 1-24.

Gould, D. M., \& Ruffin, R. J. (1996). Trade Deficits: Causes and Consequences. Economic and Financial Policy Review, (Q IV), 10-20. 
Gujarat, D. N. (1995). Basic Econometrics. $3^{\text {rd }}$ edition, McGraw-Hill Inc.

Guruli, I. (2012). Budgetary Expenses and State Debt in Georgia.

http://dfwatch.net/budgetary-expenses-and-state-debt-in-georgia-27217

(Reached at July 6, 2013)

Harrison, A. (1996). Openness and Growth: A Time-series, Cross-country Analysis for Developing Countries. Journal of Development Economics. 48:2, 419-447.

He, L. T. (2011). A Note on Impacts of International Trade on Economic Growth and Inflation. The International Trade Journal, 25:4, 418-432.

Herz1, B., \& Wagner, M. (2011). The "Real” Impact of GATT/WTO-A Generalized Approach. The World Economy. 34: 6, 1014-1041.

Hoekman, B. (2002). The WTO: Functions and Basic Principles, in Hoekman, B., Mattoo, A. \& English, P. Development, Trade, and the WTO: A Handbook, World Bank Publications.

Horn, H., Johannesson, L., \& Mavroidis, P. (2011). The WTO Dispute Settlement System 1995-2010: Some Descriptive Statistics. IFN Working Paper No. 891.

IMF. $(1997$, December).http://www.imf.org/external/np/sec/pr/1997/pr9762.htm(Reached at July 15 2012) 
Irwin, D. A. (1995). The GATT in Historical Perspective. American Economic Review. 85: 2, 323-328.

ITA. (2013).

http://www.trade.gov/mas/ian/tradeagreements/multilateral/wto/tg_ian_00206 9.asp (Reached at August 19, 2013)

Islam, S., Hye, M. A., \& Shahbaz, M. (2012). Import-Economic Growth Nexus: ARDL Approach to Cointegration. Journal of Chinese Economic and Foreign Trade Studies. 5:3, 194-214.

Ismailzade, F. (2005). Turkey-Azerbaijan: The Honeymoon is Over. http://www.turkishpolicy.com/images/stories/2005-04-neighbors/TPQ2005-4ismailzade.pdf(Reached at May 20, 2013)

Jansen. M. (2010). Developing Countries, Standards and the WTO. The Journal of International Trade \& Economic Development. 19:1, 163-185.

Kavass, I. (2008). Azerbaijan's Path toward WTO Accession: Political Concerns, Technical Difficulties, National Attitudes (1997-2006). An Essay in the Form of a Country Report, Review of Central and East European Law, 33: 3, 343384.

Kaynak, E., \& Nasirova, Z. (2005). The Transition Period of C.I.S. Economies: OilBased Economic Development Strategy of Azerbaijan. Journal of East-West Business, 10: 3. 31-51. 
Kim, D-H. (2011). Trade, Growth and Income. The Journal of International Trade \& Economic Development: An International and Comparative Review, 20:5, 677-709.

Kim, D-H., \& Lin, S-C. (2009). Trade and Growth at Different Stages of Economic Development. Journal of Development Studies, 45: 8, 1211-1224.

Kiyota, K. (2012). Trade Liberalization, Economic Growth, and Income Distribution in A Multiple-cone Neoclassical Growth Model. Oxford Economic Papers. $64: 4,655-674$.

Kim, M. H. (2008). Does the WTO Promote Trade? Further Evidence. The Journal of International Trade \& Economic Development. 19:3, 421-437.

Konya, L., Matyas, L., \& Harris, M. (2011). GATT/WTO Membership Does Promote International Trade After All-Some New Empirical Evidence, Working Paper 2011/05. Central European University.

Lee, J. (1995). Capital Goods Imports and Long-Run Growth. Journal of Development Economics. 48:1, 91-110.

Lermana, Z. (2000). Agriculture in Transition Economies: From Common Heritage to Divergence. Agricultural Economics. 26: 2, p. 96.

Liu, X. (2009). GATT/WTO Promotes Trade Strongly: Sample Selection and Model Specification. Review of International Economics. 17: 3, 428-446. 
Mansfield, E. D., \& Reinhardt, E. (2008). International Institutions and the Volatility of International Trade. International Organization. 62:4, 621-652.

Markovic, I. (2009). How to Join the World Trade Organization: Some Aspects of the Accession Process. Economic Annals. 54: 180, 118-119.

Matsushita, M. (2004). Basic Principles of the WTO and the Role of Competition Policy, Washington University Global Studies Law Review, 3:2, 363-385.

Michalopoulos, C. (2000). World Trade Organization Accession for Transition Economies: Problems and Prospects. Russian and East European Finance and Trade, 36: 2, 63-86.

Oatley, T. (2008), International Political Economy: Interests and Institutions in the Global Economy, Pearson Education, Inc.

Ognivtsev, V., Jounela, E., \& Tang, X. (2001). Accession to the WTO: The Process and Selected Issues, in WTO Accessions and Development Policies, United Nations Publication, 172-229.

Pacheco-López, P., \& Thirlwall, A. P. (2007). Trade Liberalization and the TradeOff Between Growth and the Balance of Payments in Latin America. International Review of Applied Economics, 21: 4, 469-490.

Park, W. G. (2009). Does the WTO Matter? A Non-parametric View, Working Paper Series, No. 2009-06. Economics Department, American University. 
Papava ,V. (2009). Georgia's Economy: Post-Revolutionary Development and PostWar Difficulties. Central Asian Survey. 28: 2, 199-213.

Pauwelyn, J. (2005). The Transformation of World Trade. Michigan Law Review. 104: 1, 1-70.

Rahim, S. (1999). What Use is the Neo-Classical Theory of International Trade? The Lahore Journal of Economics, 4: 1, 89-114.

Reis, R. A. (2009). The World Trade Organization, Infobase Publishing.

Rivera-Batiz, L. A., \& Xie, D. (1992). GATT, Trade, and Growth. American Economic Review. 82:2, 422-427.

Rose, A. K. (2004a). Do We Really Know That the WTO Increases Trade? The American Economic Review. 104: 1, 98-114.

Rose, A. K. (2004b). Does The WTO Make Trade More Stable? Working Paper 10207. National Bureau of Economic Research.

Rose, A. K. (2004c). Do WTO members have more liberal trade policy? Journal of International Economics. 63: 2, 209-235.

Roy, J. (2011). Is the WTO Mystery Really Solved? Economics Letters. 113, 127130. 
Santos-Paulino, A. (2005). Trade Liberalization and Economic Performance: Theory and Evidence for Developing Countries. The World Economy, 28: 6, 783-821.

Santos-Paulino, A., \& Thirlwall, A. P. (2004). The Impact of Trade Liberalization on Exports, Imports and the Balance of Payments of Developing Countries. The Economic Journal, 114:493, 50-72.

Shafaeddin, M. (2010). The Political Economy of WTO with Special Reference to NAMA Negotiations. European Journal of Development Research. 22: 2, 175-196.

Schumacher, R. (2012). Adam Smith's Theory of Absolute Advantage and the Use of Doxography in the History of Economics. Erasmus Journal for Philosophy and Economics, 5: 2, 54-80.

Shah, S. H., Hasnat, H., \& Li, J. (2010). Pre and Post WTO Analysis of South Asian Economies: Evidence from Panel Data Estimation. MPRA Paper No. 35634, http://mpra.ub.uni-muenchen.de/35634/1/MPRA_paper_35634.pdf (Reached at December 10, 2013).

Smith , J. L. (2009). The 2008 Oil Price Shock: Markets or Mayhem?RFF Policy Commentary Series. http://www.rff.org/Publications/WPC/Pages/The-2008Oil-Price-Shock-Markets-or-Mayhem.aspx (Reached at August 22, 2013)

Smith, P. A. (2001). Azerbaijan: Second Oil Boom Predicted. The Middle East, No. 314, July/August. 
Snidal, D. (1985). The limits of Hegemonic Stability Theory. International Organization. 39: 4, 579- 580.

SOCAR (2013).http://new.socar.az/socar/az/economics-and-statistics/economicsand-statistics/oil-production (Reached at December 18, 2013)

SOCAR. http://new.socar.az/socar/az/economics-and-statistics/economics-andstatistics/oil-production(Reached at July 26, 2013)

SOFAZ. (2011). Annual Report 2011. http://www.oilfund.az/uploads/annual_2011en.pdf(Reached at December 5, 2013)

Soyak, A., \& Nesirova, Z. (2003). The Consequences of IMF's Policies in the Globalization Process: The Case of Azerbaijan, Munich Personal RePEc Archive,http://mpra.ub.uni-muenchen.de/2909/(Reached at August 23, 2013)

Srinivasan, T. N. (2005). Nondiscrimination in GATT/WTO: Was There Anything to Begin with and Is There Anything Left? World Trade Review, 4: 1, 69-95.

SPSEDR (2004). http://unpan1.un.org/intradoc/groups/public/documents/untc/unpan016803.pdf (Reached at December 19, 2013) 
Staff, D. (2012). Georgia's Foreign Debt has Tripled in Five Years. Retrieved July 15, 2013, fromhttp://dfwatch.net/georgias-foreign-debt-has-tripled-in-fiveyears-49820(Reached at July 15, 2013)

CIA (2013). https://www.cia.gov/library/publications/the-worldfactbook/rankorder/2079rank.html (Reached at December 10, 2013)

Subramanian, A., \& Wei, S-J. (2007). The WTO Promotes Trade, Strongly but Unevenly. Journal of International Economics. 72: 2, 151-175.

Suleymanov, E. (2008). The Cooperation Strategy of IMF with Azerbaijan Republic after Independence with Market Economy Process. Journal of Qafqaz University, November 24, 169-179.

Swinnen, J., Olper, A., \& Vandemoortele, T. (2012). Impact of the WTO on Agricultural and Food Policies. World Economy. 35:9, pp. 1089-1101.

Taymas, Z. (1993). Azerbaijan Country Economic Memorandum: From Crisis to Sustained Growth. World Bank Report No. 117.

Thomas, J. (2006). Property Rights, Land Fragmentation and the Emerging Structure of Agriculture in Central and Eastern European Countries. Journal of Agricultural and Development Economics. 3: 2, 225-275.

Tomz, M. Goldstein, J.L., \& Rivers, D. (2007a), Do We Really Know That the WTO Increases Trade? Comment. American Economic Review, 93: 5, 2005-2018. 
Tomz, M., Rivers, D., \& Goldstein, J. L. (2007b). Institutions in International Relations: Understanding the Effects of the GATT and the WTO on World Trade. International Organization.61:1, 37-67.

TRIPS.

http://www.wto.org/english/res e/booksp e/analytic index e/trips e.htm(Rea ched at August 15, 2013)

USITC. (2003). The Impact of Trade Agreements: Effect of the Tokyo Round, USIsrael FTA, US-Canada FTA, NAFTA and the Uruguay Round on the US economy. Publication 3621.

http://www.usitc.gov/publications/332/pub3621.pdf (Reached at December 19, 2013).

Walter, A. (1996). The United States and Western Europe: The Theory of Hegemonic Stability, in Woods, N. Explaining International Relations Since 1945. Oxford University Press, 1996, 126-154.

Wangdi, K. (2010). To Join or Not to Join WTO: A Study on its Negative Impacts. Journal of Bhutan Studies. 23, Winter, 55-117.

Williams, P. J. (2008). Handbook on Accession to the WTO, Cambridge University Press.

Winters, L. A. (2004). Trade Liberalization and Economic Performance: An Overview. The Economic Journal, 114:493, 4-21. 
WTO. (2004). A handbook on the WTO Dispute System, Cambridge University Press.

WTO (2011), Understanding of WTO. WTO Publication.

http://www.wto.org/english/thewto_e/whatis_e/tif_e/understanding_e.pdf(Rea ched at December 15, 2013)

WTO. (2012). World Trade Report 2012, WTO Publications.

Yunusov, A. (2001). Twenty Years of Independence in Azerbaijan, in South Caucasus 20 Years of Independence, Friedrich-Ebert-Stiftung. 60-77. 